\title{
1 Patterns of variation in canal and root number in 2 human post-canine teeth
}

3 Authors: Jason J. Gellis and Robert A. Foley

4

5 University of Cambridge Leverhulme Centre for Human Evolutionary Studies

6

7

8

9

10

11

12

13

14

15

16

17

18

19

20

21

22

23

24

25

26

27 
60

61

62

63

\section{Abstract}

Descriptive morphology of tooth roots traditionally focuses on number of canals and roots. However, how or if canal and root number are related is poorly understood. While it is often assumed that canal number is concomitant with root number and morphology, in practice canal number and morphology do not always covary with external root features. To investigate the relationship between canal and root number, fully developed, adult postcanine teeth were examined and quantified from medical computerized tomography scans from a global sample of 945 modern humans. We tested the hypotheses that root and canal number do not follow a 1:1 ratio, that canal to root ratios differ between teeth, and that canal to root ratios differ across populations. Results indicate that not only is root number dependent on canal number, but that this relationship become more variable as canal number increases, varies both between individual teeth and by population, and changes as populations increase in distance from Sub-Saharan Africa. These results show that the ratio of canal number to root number is an important indicator of variation in dental phenotypes.

Key words: Tooth roots, human diversity, dental anthropology, tooth root morphology, root canal morphology, human dental evolution 


\section{Introduction}

Tooth root anatomy varies in canal and root number, and canal number does not always covary with root number. Various aspects of this have been studied in modern humans (Kovacs, 1971; Ackerman et al., 1973; Vertucci and Gegauff, 1979; Hsu and Kim, 1997; Zorbaa et al., 2014; Ahmed et al., 2017), extant hominoids (Kupczik et al., 2005; Emonet et al., 2012; Moore et al., 2013, 2015), and fossil hominins (Wood et al., 1988a; Plavcan and Daegling, 2006; Kupczik et al., 2009; Kupczik and Hublin, 2010; Le Cabec et al., 2013; Moore et al., 2016). However, the numerical relationship between canals and roots is poorly understood. This study uses medical CT scans to investigate the relationship and variability between canal and root number of fully developed, adult post-canine teeth in a global sample of modern humans ( $n=945$ individuals) from several archaeological/osteological collections. Specifically, we asked (1) what is the relationship between root number and canal number; (2) does this relationship vary by tooth; and (3) does the relationship between canal and root number vary in global groups?

\section{Root and canal formation}

Tooth canal and root formation are comprised of a series of reciprocal cellular interactions in the dental papilla of the developing tooth (Jernvall and Thesleff, 2000). Central to the process, is Hertwig's epithelial root sheath (HERS), which is derived from the cervical loop of the enamel organ and is thought to be responsible for root number, shape and length (Nanci, 2012; Luder, 2015). Following crown formation, mesenchyme cells form the blood vessels, nerves, and connective tissue of the pulp cavity and root canals (Wright, 2007). Simultaneously, the HERS extends apically, interacting with the mesenchyme cells of the developing canal structures, and differentiating into odontoblasts responsible for dentin and cementum production (Li et al., 2017).

During root morphogenesis, the HERS produces inter-radicular processes (IRP's), finger-like protrusions adjacent the cervical foramen of the tooth crown. The extension and fusion of opposing IRPs across the cervical foramen create multiple secondary foramina which, in turn, form multiple tooth roots (Kovacs, 1971; Orban and Bhaskar, 1980); and it may be that number and orientation of IRP's are responsible for the variation in canal and root forms (Figure 1). While molecular regulation and tooth morphogenesis have been 
extensively studied in tooth crowns, the mechanisms responsible for variation in canal and root structures is poorly understood. Because of its extensive role in root formation, HERS has been an area of focus; and several studies have shown that disturbances in formation of the HERS results in abnormalities in root number and shape (see Luder, 2015 for a review).

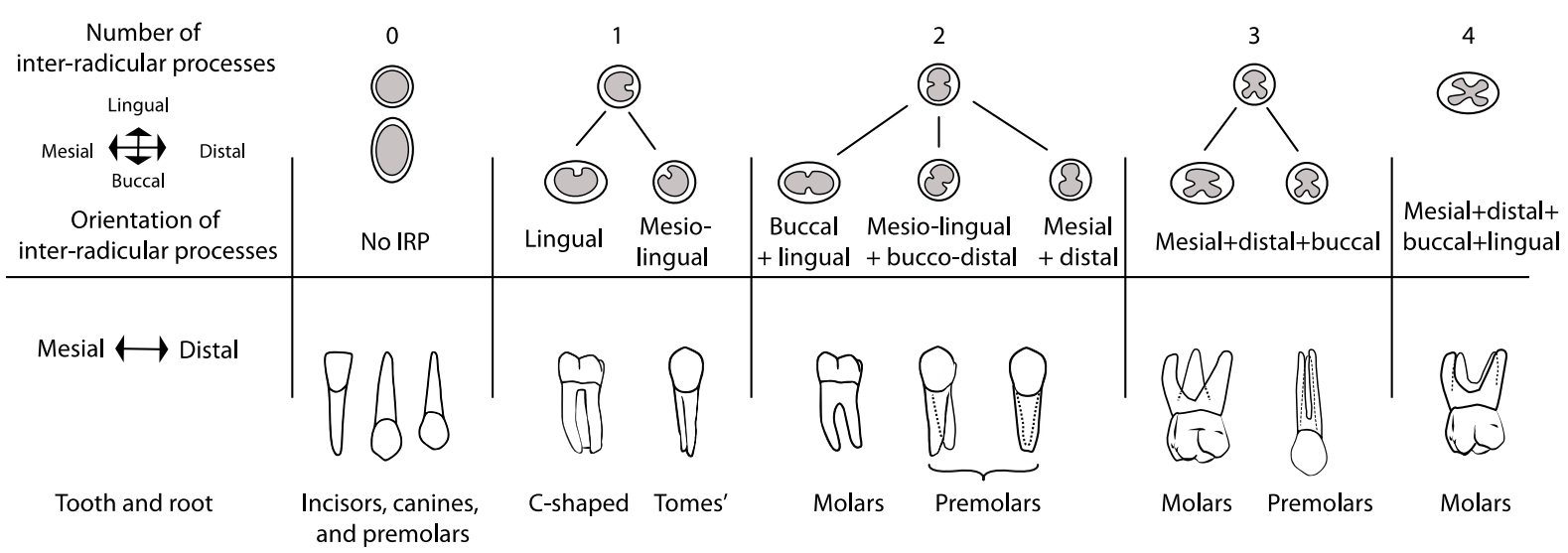

Figure 1: Top: The location and on the apical foramen of the tooth crown where the inter-radicular processes (IRP's) form determines the number and orientation of each tooth root/tooth roots. For example, in a tooth with mesial and distal roots, two inter-radicular processes arise from the buccal and lingual borders of the apical foramen, forming mesial and distal secondary apical foramina upon fusion. Grey = apical foramina of the developing tooth crown. Bottom: Fully developed roots of different types of teeth with the same number, but different orientation of IRPs. From right to left: single rooted teeth, single rooted teeth in which IRP did not fuse with opposing side of apical foramen, 2 rooted teeth in which 2 opposing IRPs fused, 3 rooted teeth in which 3 opposing IRPs fused, 4 rooted teeth in which 4 opposing IRPs fused.

Though morphogenesis of internal and external root structures are concurrent processes, the completed structures do not always covary. There is great variation and complexity in root canals. While it is easy to conceptualize canals as round holes which taper towards the roots' apex, in reality, many teeth have multiple canals of differing shape and orientation within a single root. These canals can join and separate in unpredictable places and the more ovoid the cross-section the greater the propensity for complexity (Vertucci and Gegauff, 1979; De Pablo et al., 2010; Ahmed et al., 2017). Possible causes of divergence in canal and root number have been attributed to uneven deposition of dentin on the walls of the canal (Manning, 1990), trauma to the HERS by radiation or chemical interference (Fischischweiger and Clausnitzer, 1988), and/or failure of the HERS to fuse on different sides of the root (Nelson and Ash, 2010; Nanci, 2012).

In this paper we (1) test the hypothesis that there is no difference between canal and root number in the pooled post-canine teeth in our sample; (2) test the relationship between canal and root number in the individual post-canine teeth of the jaws; (3) test the 
bioRxiv preprint doi: https://doi.org/10.1101/2022.02.01.478656; this version posted February 3, 2022. The copyright holder for this preprint (which was not certified by peer review) is the author/funder, who has granted bioRxiv a license to display the preprint in perpetuity. It is made available under aCC-BY-NC-ND 4.0 International license.

124

relationship between canal and root number in pooled and individual teeth, by geographical regions.

\section{Materials and Methods}

\section{Dental formula}

Categorically premolars with $\mathrm{P}$, and molars with $\mathrm{M}$. Tooth numbers are labelled with super- and subscripts to differentiate the teeth of the maxilla and mandible respectively. For example, $\mathrm{M}^{1}$ indicates the 1 st maxillary molar while $\mathrm{M}_{1}$ indicates the 1 st mandibular molar.. Through the course of evolution, apes and old world monkeys have lost the first and second premolars of their evolutionary ancestors (Novacek, 1986; White et al., 2012), thus the remaining 2 premolars are numbered 3 and 4 .

\section{Human samples}

The 945 individuals used in this study were recovered from archaeological sites across the globe (Figure 2). These individuals are stored in osteological collections at the Smithsonian National Museum of Natural History, Washington D.C., USA (SI), American Museum of Natural History, New York, USA (AMNH), and the Duckworth Laboratory (DW) at the University of Cambridge, England (summarized in Figure 3). Only adult individuals, based on the eruption, occlusion, and closed root apices of $\mathrm{M}^{3} / \mathrm{M}_{3}{ }^{\prime} \mathrm{s}$ (or $\mathrm{M}^{2} / \mathrm{M}_{2}$ 's in the case of congenitally absent $\mathrm{M}^{3} / \mathrm{M}_{3}$ 's), were used in this study.

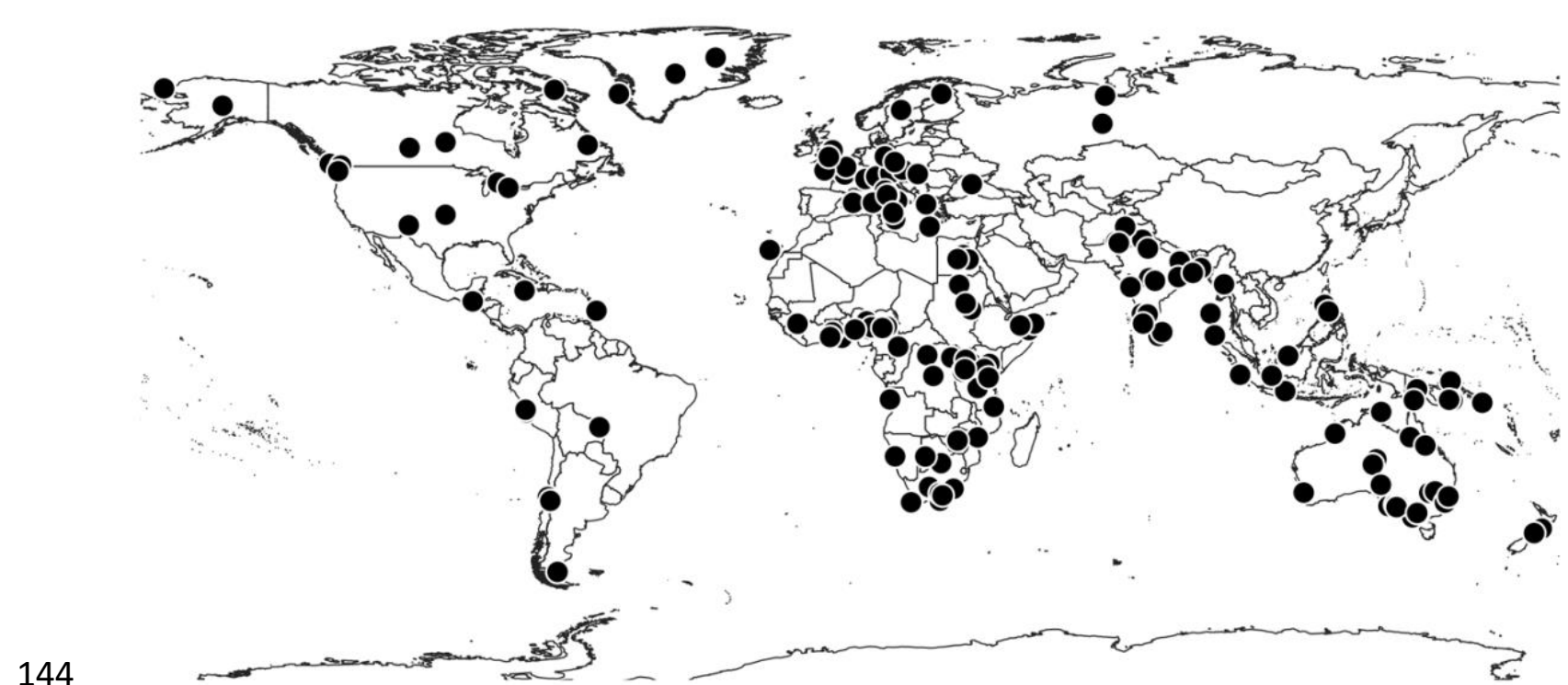

Figure 2: Map of archaeological sites for individuals used in this study. 
bioRxiv preprint doi: https://doi.org/10.1101/2022.02.01.478656; this version posted February 3, 2022. The copyright holder for this preprint (which was not certified by peer review) is the author/funder, who has granted bioRxiv a license to display the preprint in perpetuity. It is made available under aCC-BY-NC-ND 4.0 International license.

\section{American Museum of Natural History}

The 186 individuals from the AMNH collection are comprised of humans from Point Hope, Alaska, North America (Figure 3, right). These individuals, are attributed to the Ipiutak (500 BCE - 500 CE) and Tigara (1300-1700 CE) cultures (Rainey, 1941, 1947, 1971; Larsen and Rainey, 1948). Information on sex (Figure 4) and antiquity come from the AMNH archives and publications associated with the collection (ibid).
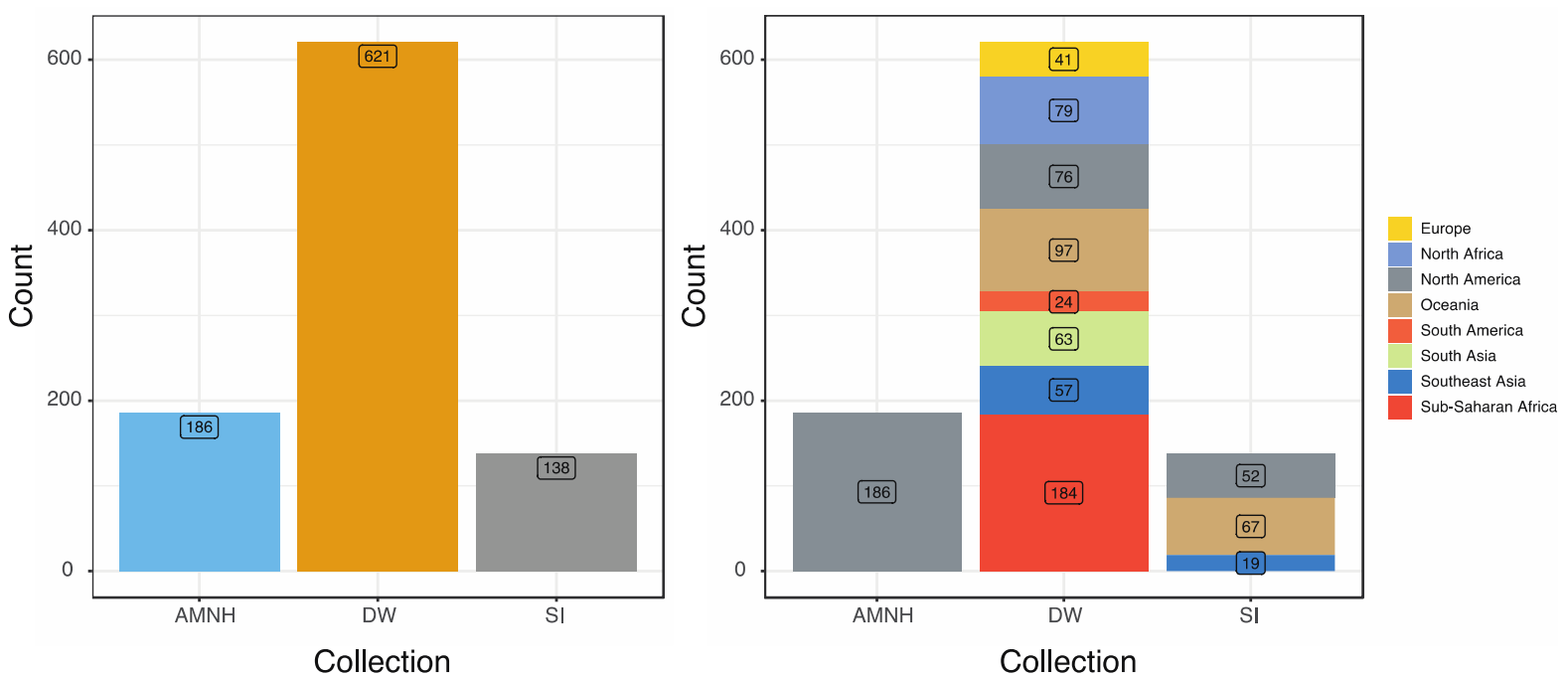

Figure 3: Human population sample sizes by collection. Left: Bar plot of counts for entire sample $(n=945)$.

Right: Counts of samples divided up by collection, and geographic locations given by collection records. A complete list of the individuals used in this study, their collection information, antiquity, sex, and locality based on available records is listed in Supplementary Materials Table A.

\section{Duckworth Laboratory}

The majority of individuals $(n=621)$ used in this study come from the DW Laboratory collections (Figure 3, right). The DW is comprised of several private collections as well as research collections from the University of Cambridge Departments of Zoology, Anatomy, and Museum of Archaeology and Anatomy (Mirazón-Lahr, 2011). The oldest individuals used in this study come from the archaeological sites of Badari, Egypt (4000-3200 BCE), Jebel Moya, Sudan (100 BCE-500 CE) and Ngada, Egypt (4400-4000 BCE), in North-East Africa. The majority of the remaining individuals are $~ 200$ years old. In many cases information on exact locality, age, and age of death, is unavailable. Information on sex (Figure 4) comes from DW archives. A complete list of the DW individuals used in this study, their collection information, antiquity, sex, and locality based on available records is listed in Supplementary Materials Table A. 
bioRxiv preprint doi: https://doi.org/10.1101/2022.02.01.478656; this version posted February 3, 2022. The copyright holder for this preprint (which was not certified by peer review) is the author/funder, who has granted bioRxiv a license to display the preprint in perpetuity. It is made available under aCC-BY-NC-ND 4.0 International license.

172

\section{Smithsonian National Museum of Natural History}

The 138 individuals from the SI collection are from Oceania, Southeast Asia, and Greenland. Individuals from Oceania belong $(n=67)$ to four different populations: Australia (Aboriginal), New Zealand (Maori), the Philippines, and Papua New Guinea (Figure 3, right). Individuals from Southeast Asia $(n=19)$ are from Indonesia. Inuit individuals comes from the North-West coast of Greenland $(n=52)$. While all SI individuals were recovered from archaeological sites, information on exact locality, age, and age of death, is unavailable. However, information on sex taken from archives at the SI (Figure 4) as reported in Copes (2012).
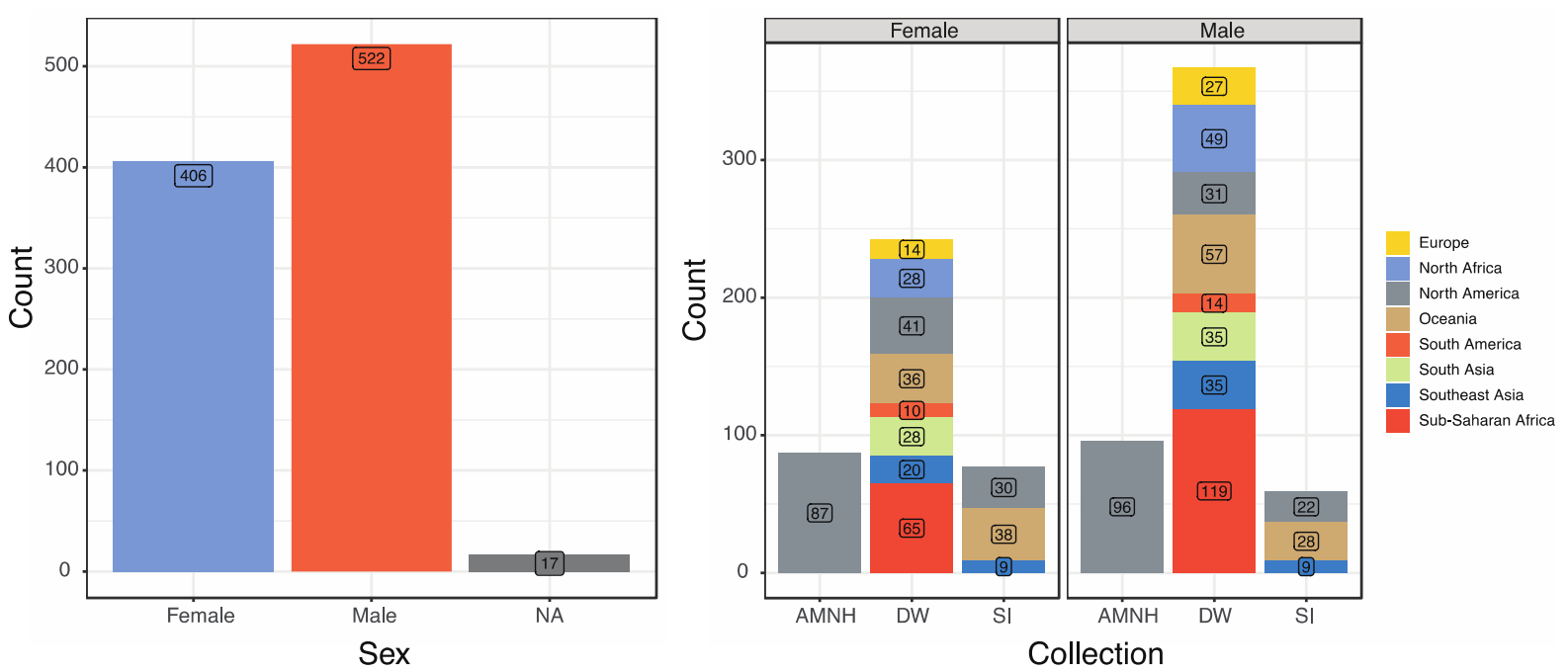

Figure 4: Human population sample sizes by location and sex. Left: Bar plot of sex for entire sample $(n=945)$. Right: Sex divided up by collection and geographic locations given by collection records. Individuals of undetermined sex ('NA') are not included in the plot on the right to improve readability. They are: AMNH (NA $=3)$, DW (NA = 12), and SI (NA = 2). A complete list of the individuals used in this study, their collection information, antiquity, sex, and locality based on available records is Supplementary Materials Table A.

The populations in this study have been, at their broadest level, grouped into five major human populations: Sub-Saharan Africa, West-Eurasia, Sahul-Pacific, Sunda-Pacific, and Sino-Americas (Table 1 \& Figure 5). Though Table 1 reports information for sex, this is for descriptive purposes. All analyses and reported results are for pooled sex samples. A complete list and description of individuals included in this study is listed in the Supplementary Materials Table A. 
Table 1: Sample populations used in this study

\begin{tabular}{lcccc}
\hline Populations* & Male & Female & Unknown & Total \\
\hline Sahul-Pacific & 84 & 74 & 9 & 167 \\
Sunda-Pacific & 42 & 28 & 3 & 73 \\
Sub-Saharan Africa & 119 & 65 & - & 184 \\
West Eurasia & 111 & 70 & 2 & 183 \\
Sino-Americas & 163 & 168 & 7 & 338 \\
Total & 519 & 405 & 21 & 945 \\
\hline
\end{tabular}

199

200

201

202

203

204

205

206

207

208

209

210

211

212

213

214

215

216

217

218

219

220

221

222

These groupings are derived from two major works. The first is Cavalli-Sforza's The History and Geography of Human Genes (1994), a synthesis of global genetics with nearly half a century's worth of geographical, ecological, linguistic, archaeological, and paleoanthropological research. Among the author's many conclusions are that all available evidence points to 1 ) an African origin for $H$. sapiens; and 2) the fact that a series of dispersal and admixture events can classify and map where major human populations (as listed above) and their subsequent subdivisions originated and dispersed through the ancient world. The volume (1994:317) also recognises that dental data "on northern Asia, southeast Asia, and the Americas are generally in excellent agreement with those from single genes." The dental data they refer to are crown and root trait frequencies collected and analysed by Christy Turner (Nichol et al., 1984; Turner II, 1986, 1987, 1989). These data, along with later core collected works on dental crown traits and biogeography utilising the ASUDAS (Scott, 1988; Turner II et al., 1991; Stringer et al., 1997; Irish, 1998; Hanihara, 2013; Scott et al., 2018), form the second basis for major human geographical subdivisions presented here. These researchers (ibid) have shown that teeth are effective for identifying the same prehistoric population identities and movements discussed by Cavalli-Sforza (1994), as well as capturing the phenotypic diversity within populations, and the differences that arise between them after extended periods of isolation. The most current collections of dental anthropological research (Rathmann et al., 2017; Scott et al., 2018; Rathmann and Reyes-Centeno, 2020) are increasingly in accordance with the most recent genomic studies (Pickrell and Reich, 2014; Fu et al., 2016; Skoglund et al., 2016; Rathmann et al., 2017; Posth et al., 2018; Reich, 2018), further reinforcing the utility of teeth as phenotypic records of human biogeography and evolutionary history. 


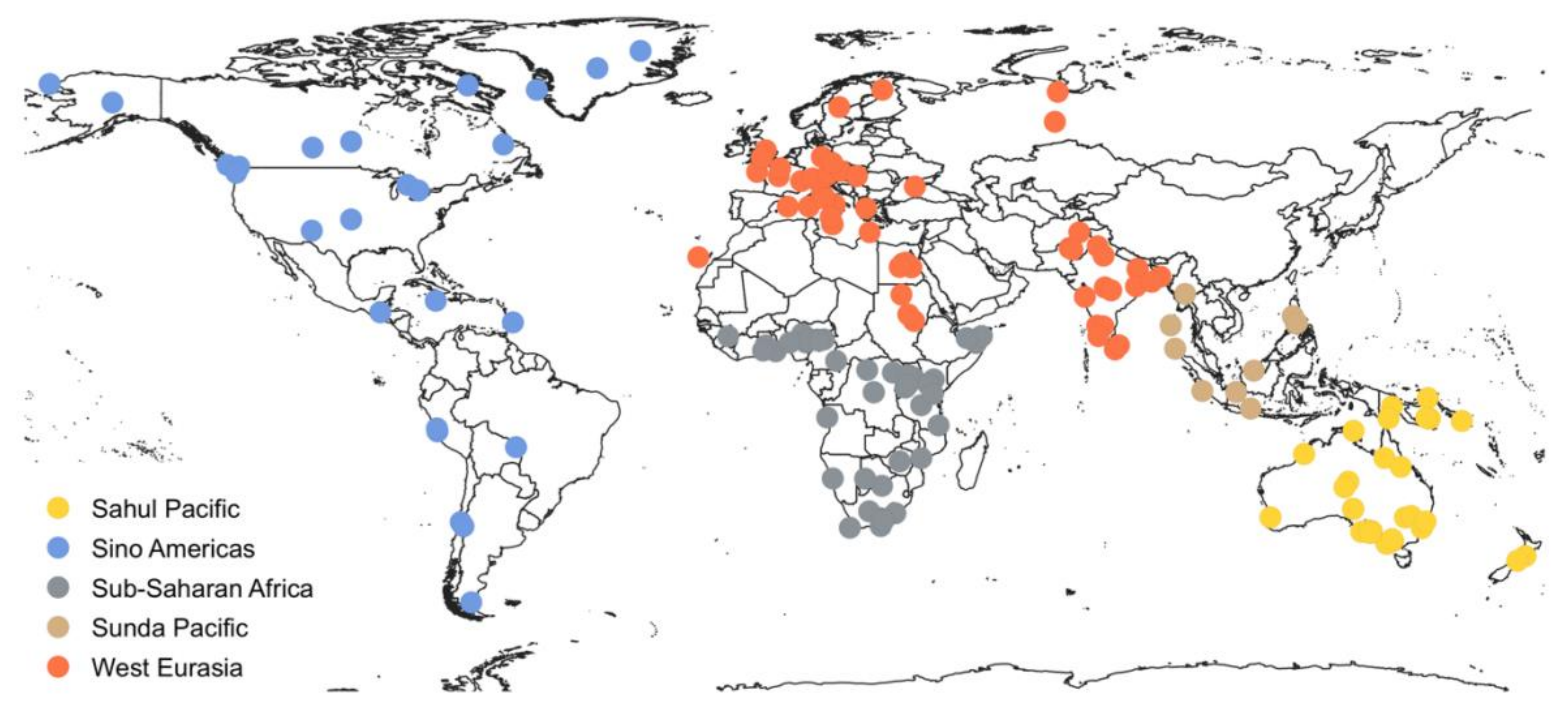

Figure 5: Map of archaeological sites for individuals used in this dissertation adapted to show the five major human populations.

Use of cone beam computed tomography for visualizing internal and external features of tooth roots

In clinical settings (e.g., dental, hospital, etc.), cone beam computed tomography

232 ( root(s) (see Martins and Versiani (2018) for an in-depth discussion of this topic). An important parameter supporting reliability of visualization for the study of root and canal anatomy is voxel size. In 3D medical imaging a single voxel is a cubic representation of a

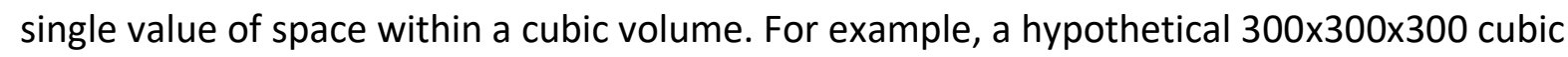
volume would have $27,000,000$ voxels. Thus, the lower the voxel size relative to the volume of 3D CBCT, the greater the resolution. Compared to micro-CT $(\mu C T)$ which operates on the micron scale (a thousandth of a millimetre) for increased resolution, CBCT uses larger voxel sizes at the millimetre scale which results in a relatively decreased resolution. However, CBCT has been proven to be reliable for detecting root an canal number and morphology in specific teeth or individual roots (Blattner et al., 2010; Michetti et al., 2010; Domark et al., 2013; Pécora et al., 2013). Maret et al. (2014) compared in vitro CBCT images of different voxel sizes $(76,200$, and $300 \mu \mathrm{m})$ with $\mu \mathrm{CT}(41 \mu \mathrm{m})$ and observed discrepancies of hard tissue morphology (i.e. cervical margins, cusp tips, incisal edges) were only significant at $300 \mu \mathrm{m}(\mathrm{P}=.01$, Wilcoxon test). These studies (additionally, see Martins and Versiani (2018) for an extensive overview of $\mathrm{CBCT}$ and $\mu \mathrm{CT}$ on root canal anatomy by tooth) have shown 
that $\mathrm{CBCT}$ can clearly and accurately detect structures such as root number, canal number, and configuration of the main root canal systems.

\section{Imaging of osteological collections}

Following the method developed by Gellis and Foley (2021) we used cone-beam computed tomography (CT) to analyse 5,970 post-canine teeth (Table 2 ) from the right sides of the maxillary and mandibular dental arcades of individuals $(n=945)$ from a global sample of humans (Table 1). While information for all teeth from both sides of the maxillary and mandibular arcades was recorded, only the right sides were analysed to avoid issues with asymmetry and artificially inflated sample size. Full skulls of specimens from the SI and AMNH were scanned by Dr. Lynn Copes (Copes, 2012) using a Siemens Somatom spiral scanner $\left(70 \mu \mathrm{A}, 110 \mathrm{kV}\right.$, slice thickness $1.0 \mathrm{~mm}$, reconstruction $0.5 \mathrm{~mm}$, voxel size $\mathrm{mm}^{\wedge} 3$ : $0.5 \times 0.5 \times 0.3676)$. Full skulls from the DC were scanned by Professor Marta Miraźon-Lahr and Dr. Frances Rivera (Rivera and Mirazón-Lahr, 2017) using a Siemens Somatom Definition Flash scanner at Addenbrooke's Hospital, Cambridge England $(80 \mu \mathrm{A}, 120 \mathrm{kV}$, slice thickness $0.6 \mathrm{~mm}$, voxel size $\left.\mathrm{mm}^{\wedge} 3: 0.3906 \times 0.3906 \times 0.3\right)$. For all collections, crania and mandibles were oriented on the rotation stage, with the coronal plane orthogonal to the $\mathrm{x}$-ray source and detector. Permission to use the scans has been granted by Dr. Copes, Professor MiraźonLahr and Dr. Rivera.

Table 2: Tooth counts of the right side of the maxillary and mandibular dental arcades.

\begin{tabular}{|c|c|c|c|c|}
\hline Tooth & $\mathrm{n}$ & Tooth & $n$ & Total \\
\hline \multicolumn{2}{|c|}{ Maxilla } & \multicolumn{2}{|c|}{ Mandible } & \\
\hline $\mathbf{P}^{3}$ & 515 & $\mathbf{P}_{3}$ & 343 & 858 \\
\hline $\mathrm{P}^{4}$ & 467 & $\mathbf{P}_{4}$ & 313 & 780 \\
\hline $\mathbf{M}^{1}$ & 697 & $\mathbf{M}_{1}$ & 410 & 1,107 \\
\hline$M^{2}$ & 596 & $\mathbf{M}_{2}$ & 385 & 981 \\
\hline $\mathbf{M}^{3}$ & 362 & $M_{3}$ & 278 & 640 \\
\hline Total & 3,495 & - & 2,475 & 5,970 \\
\hline
\end{tabular}
parentheses indicate congenitally absent teeth (discussed in section). 
Viewer (Figure 6) version 3.5.5 (https://www.horosproject.org, 2016). Only permanent teeth with completely developed roots and closed root apices were used for this study. While information for all teeth from both sides of the maxillary and mandibular arcades was recorded, only the right sides were analysed to avoid issues with asymmetry and artificially inflated sample size.
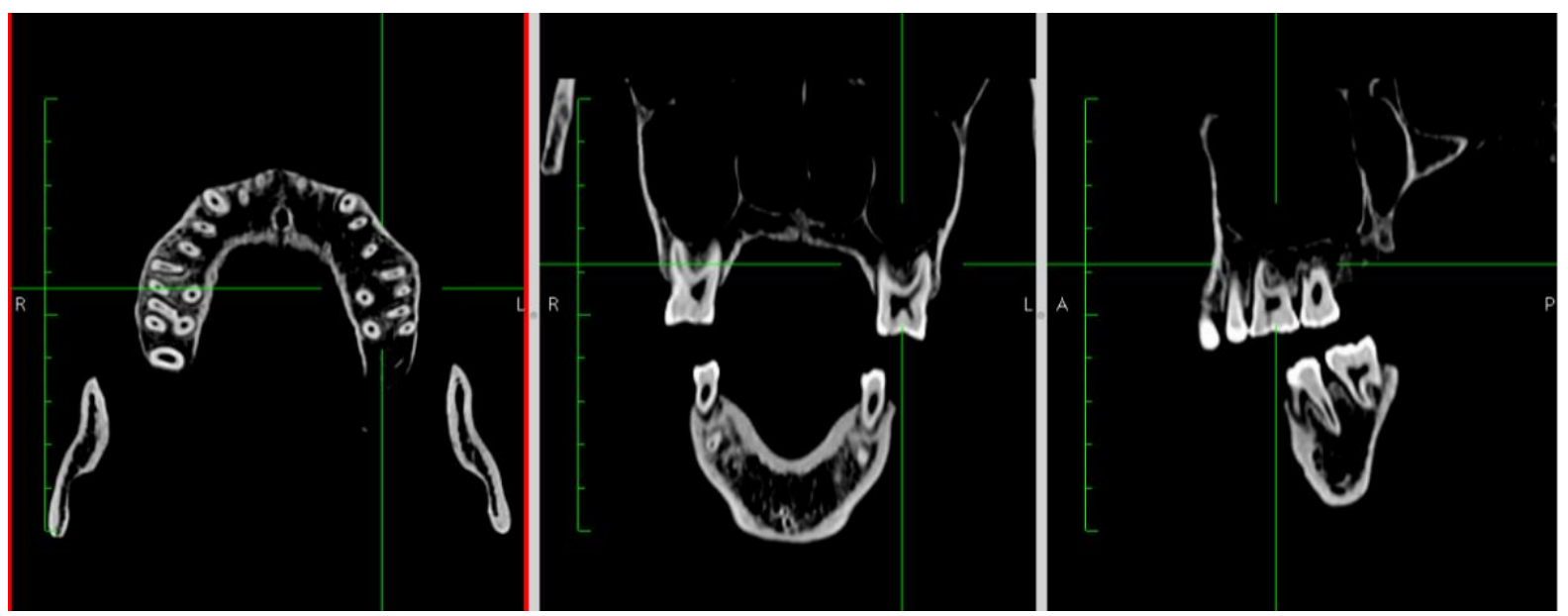

Figure 6: Horos Dicom Viewer 2D orthogonal view used to assess root and canal morphologies. Left: Coronal view at mid-point of roots. Centre: Anterior view at midpoint of roots. Right: Lateral view at midpoint of roots.

\section{Determination of root and canal number}

Root and canal number are determined by applying the Turner Index (1991), which compares the point of bifurcation relative to total root or canal length, as measured in Horos Dicom Viewer from the cemento-enamel junction (CEJ) to the root apex/canal apical foramen (Figure 3). When this ratio is greater than one-third (33\%) of the total root or canal length, the root or canal is classified as multi-rooted. When the ratio is less than one-third (33\%) the root or canal is considered single rooted, or with a bifid apical third. Individual root/canal number for analysis is recorded as a simple numerical count (e.g., 1,2,3, etc.). Using measurement tools in Horos Dicom Viewer, the midpoint of the root was measured halfway between the CEJ and the apices of the root/s (Figure 7). It is by these methods that data were acquired for the analyses described and carried out through this study. Here, a single root canal is defined as a canal which extends from the pulp chamber within the crown and exits at a single foramen. Accessory canals are not included in this study. 

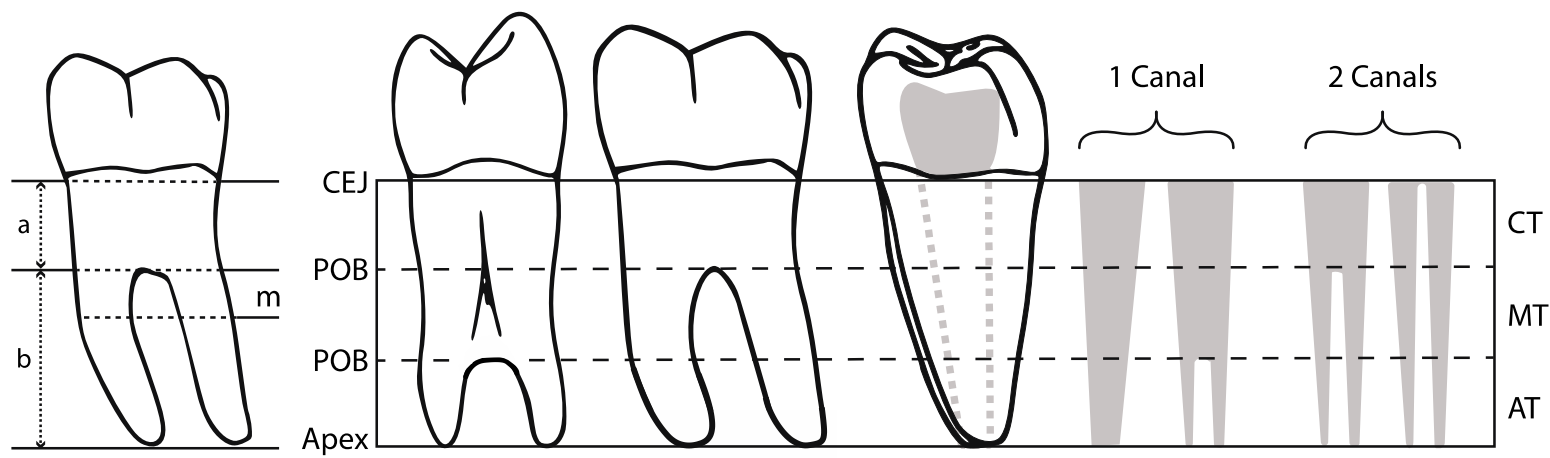

Figure 7: Left: Locations of measurements taken in Horos Dicom Viewer of (a) CEJ to point of bifurcation, (b) point of bifurcation to root apices, $(\mathrm{m})$ mid-point between CEJ and root apices. Right: Determination of root and canal number. Distal view of single-rooted premolar with bifurcation of the apical third of the root. Lingual view of double-rooted mandibular molar. Distal root of double-rooted mandibular molar with examples of canal counts in solid grey. Dotted grey lines indicate canal/s position in root. CEJ = Cemento-enamel junction, $\mathrm{POB}=$ Point of bifurcation, Solid grey = canals. $\mathrm{CT}=$ cervical third, MT = middle third, AT = apical third.

\section{Statistical analyses}

Data were analysed with the R Project for Statistical Computing. Because the osteological materials used in this study were recovered from excavation sites, many of the individuals comprising our sample are missing one or more teeth. As the mechanism causing these missing data are unrelated to the values of any variables used in analysis (missing completely at random), our observed values are essentially a random sample of the full data set and not biased (Sterne et al., 2009). Thus, multiple imputation is appropriate for our data set (Garson, 2015; Zhang et al., 2017). Using the missMDA package, we performed multiple imputation on missing data in preparation for analysis (Josse and Husson, 2016).

Because the Poisson distribution is typically used for count data, a Poisson general linear model (PGLM) was used to test the association between canal and root number at the $p=0.05$ significance level (Zeileis et al., 2008). A key assumption underlying PGLM is the independence of observations (Hoffmann, 2004). Thus, the inclusion of multiple teeth from the same individuals may violate assumptions of independence for the PGLM used in this study. To account for this, we fit our PGLM with Generalized Estimating Equations (GEE). GEE estimates population-averaged parameters and their standard errors based on a number of assumptions: (1) The responses variables are correlated or clustered; (2) There is a linear relationship between the covariates and a transformation of the response; and (3) within-subject covariance has a correlation structure (Zeger and Liang, 1986; Diggle et al., 2002). In order to determine our correlation structure and how root and canal number correlated within and between teeth we conducted a Pearson correlation analysis of canal 
and root number. We selected and Auto Regressive Order 1 (AR1) correlation structure for our GEE covariance matrix. While GEE estimates of model parameters are valid regardless of the specified correlation structure, the AR1 correlation structure is appropriate because it (a) has no distributional assumptions (Zuur et al., 2009); (b) can accurately model covariance for cross-sectional individual and clustered studies (Müller et al., 2009; Muoka et al., 2021); (c) accurately model within-subject correlation decreasing across time and/or space (Agresti, 2002); and (d) assumes observations within and individual are non-independent (Zeger and Liang, 1986). Thus, AR1 is appropriate at the individual and population levels, and for the temporospatial distances within and between individuals and groups within our sample. GEE was caried out using 'geepack: Generalized Estimating Equation Package' version 1.3.2 (Halekoh et al., 2006). Stepwise model selection was tested and quantified using Akaike Information Criteria (stepAIC). Tukey's multiple comparison test was used for pair-wise analysis of population groups (Full statistical output is presented in Appendix Section 9.3). PGLM extended with GEE was also used to test for association between root and canal number by tooth and population groups. Tukey's multiple comparison test was used for pair-wise analysis of population groups.

\section{Results}

\section{Number of teeth, roots, and canals}

Tables 3 and 4 report counts for number of roots and canals from post-canine teeth belonging to the right side of the maxilla and mandible. The number of roots in teeth from the sample are between one and four (Table 3). In this sample, teeth with four roots are limited to maxillary molars and appear with a relatively low frequency compared to 2 and 3 rooted teeth. Premolars, especially $\mathrm{P}_{3}$ and $\mathrm{P}_{4}$, are predominantly single-rooted, while the majority mandibular molars in this sample are double-rooted. Entomolaris (En), or threerooted molars, appear in $18.05 \% \mathrm{M} 1 \mathrm{~s}, 1.23 \%$ of $\mathrm{M} 2 \mathrm{~s}$, and $5.94 \%$ of $\mathrm{M}_{3} \mathrm{~s}$, and three-rooted paramolaris $(\mathrm{Pa})$ appears in $3.63 \%$ of $\mathrm{M}_{3} \mathrm{~S}$. 
Table 3: Number of roots in teeth of the maxilla and mandible by tooth

\begin{tabular}{|c|c|c|c|c|c|c|c|c|c|}
\hline Tooth & $\begin{array}{c}\text { Root } \\
\text { number }\end{array}$ & $\mathrm{n}$ & $\begin{array}{l}\text { Total } \\
\text { Roots }\end{array}$ & $\begin{array}{l}\% \text { of } \\
\text { teeth* }\end{array}$ & Tooth & $\begin{array}{c}\text { Root } \\
\text { number }\end{array}$ & $\mathrm{n}$ & $\begin{array}{l}\text { Total } \\
\text { Roots }\end{array}$ & $\begin{array}{l}\% \text { of } \\
\text { teeth* }\end{array}$ \\
\hline \multicolumn{5}{|c|}{ Maxilla } & \multicolumn{5}{|c|}{ Mandible } \\
\hline \multirow[t]{3}{*}{$\mathbf{P}^{3}$} & 1 & 295 & 739 & 57.28 & $\mathbf{P}_{3}$ & 1 & 341 & 99.42 & 345 \\
\hline & 2 & 216 & & 41.94 & & 2 & 2 & 0.58 & \\
\hline & 3 & 4 & & 0.78 & & & & & \\
\hline \multirow[t]{3}{*}{$P^{4}$} & 1 & 405 & 530 & 86.72 & $\mathbf{P}_{4}$ & 1 & 313 & 100.0 & 313 \\
\hline & 2 & 61 & & 13.06 & & & & & \\
\hline & 3 & 1 & & 0.22 & & & & & \\
\hline \multirow[t]{4}{*}{$\mathbf{M}^{1}$} & 1 & 2 & 2,060 & 0.29 & $M_{1}$ & 2 & 336 & 81.95 & 894 \\
\hline & 2 & 28 & & 4.02 & & $3^{* *}$ & 74 & 18.05 & \\
\hline & 3 & 666 & & 95.55 & & & & & \\
\hline & 4 & 1 & & 0.14 & & & & & \\
\hline \multirow[t]{4}{*}{$M^{2}$} & 1 & 56 & 1,561 & 9.39 & $M_{2}$ & 1 & 49 & 12.73 & 727 \\
\hline & 2 & 117 & & 19.63 & & 2 & 330 & 85.71 & \\
\hline & 3 & 421 & & 70.64 & & 3 & 1 & 0.26 & \\
\hline & 4 & 2 & & 0.34 & & $3 * *$ & 5 & 1.30 & \\
\hline \multirow[t]{4}{*}{$M^{3}$} & 1 & 89 & 831 & 24.59 & $M_{3}$ & 1 & 20 & 7.19 & 563 \\
\hline & 2 & 82 & & 22.65 & & 2 & 231 & 83.09 & \\
\hline & 3 & 186 & & 51.38 & & 3* & 16 & 5.76 & \\
\hline & 4 & 5 & & 1.38 & & $3+$ & 11 & 3.96 & \\
\hline
\end{tabular}
exceeds root number (Table 4). Many teeth contain two or more canals, especially in the molars. Molars have the greatest number of canals per tooth, with $\mathrm{M}^{1} \mathrm{~s}$ showing the most variation in canal number. 
Table 4: Number of canals per tooth in the maxilla and mandible by tooth

\begin{tabular}{cccccccccc}
\hline Tooth & $\begin{array}{c}\text { Canal } \\
\text { number }\end{array}$ & $\mathrm{n}$ & $\begin{array}{c}\text { Total } \\
\text { Canals }\end{array}$ & $\begin{array}{c}\text { \% of } \\
\text { teeth* }\end{array}$ & Tooth & $\begin{array}{c}\text { Canal } \\
\text { number }\end{array}$ & $\mathrm{n}$ & $\begin{array}{c}\text { Total } \\
\text { Canals }\end{array}$ & $\begin{array}{c}\text { \% of } \\
\text { teeth* }\end{array}$ \\
\hline $\mathbf{P}^{3}$ & 1 & 82 & 959 & 15.92 & $\mathbf{P}_{\mathbf{3}}$ & 1 & 254 & 433 & 74.05 \\
& 2 & 422 & & 81.94 & & 2 & 88 & & 25.66 \\
& 3 & 11 & & 2.14 & & 3 & 1 & & 0.29 \\
$\mathbf{P}^{4}$ & 1 & 233 & 708 & 49.89 & $\mathbf{P}_{\mathbf{4}}$ & 1 & 300 & 326 & 95.85 \\
& 2 & 228 & & 48.82 & & 2 & 13 & & 4.15 \\
& 3 & 5 & & 1.07 & & & & & \\
& 4 & 1 & & 0.22 & & & & & \\
$\mathbf{M}^{1}$ & 2 & 4 & 2,430 & 0.57 & $\mathbf{M}_{1}$ & 2 & 27 & 1,421 & 6.58 \\
& 3 & 355 & & 50.93 & & 3 & 168 & & 40.98 \\
& 4 & 334 & & 47.92 & & 4 & 212 & & 51.71 \\
& 5 & 3 & & 0.43 & & 5 & 3 & & 0.73 \\
& 6 & 1 & & 0.14 & & & & & \\
$\mathbf{M}^{2}$ & 1 & 8 & 1,910 & 1.34 & $\mathbf{M}_{\mathbf{2}}$ & 1 & 2 & 1,093 & 0.52 \\
& 2 & 21 & & 3.52 & & 2 & 105 & & 27.27 \\
& 3 & 408 & & 68.46 & & 3 & 231 & & 60.0 \\
& 4 & 159 & & 26.68 & & 4 & 47 & & 12.21 \\
$\mathbf{M}^{3}$ & 1 & 32 & 1,065 & 8.84 & $\mathbf{M}_{3}$ & 1 & 10 & 747 & 3.60 \\
& 2 & 24 & & 6.63 & & 2 & 86 & & 30.94 \\
& 3 & 239 & & 66.02 & & 3 & 163 & & 58.62 \\
& 4 & 67 & & 18.51 & & 4 & 19 & & 6.84 \\
\hline
\end{tabular}

392

* From Table 2. Congenitally absent teeth not included in statistics for this table.
393

394

395

396

397

398

399

400

401

402

403

\section{Inter-trait correlation}

Pearson product-moment correlation coefficients (Figure 8) were computed to assess linear correlation between root number (RN) and canal number ( $C N)$ for teeth used in this study (Table 2). The majority of variables have negligible to weak positive or negative correlation coefficient strength values of $0.01- \pm 0.30$ (Akoglu, 2018). Within same teeth moderate to strong correlation coefficient values of $0.31- \pm 0.69$ (ibid) are found in $\mathrm{P}^{4} \mathrm{RN}: \mathrm{P}^{4}$ $C N(0.46), M^{3} R N: M^{3} C N(0.47), M_{2} R N: M_{2} C N(0.35)$, and $M_{3} R N: M_{3} C N(0.50)$. With the exception of $\mathrm{P}^{3} \mathrm{RN}: \mathrm{P}^{4} \mathrm{CN}(0.46), \mathrm{P}^{3} \mathrm{RN}: \mathrm{P}^{4} \mathrm{CN}(0.65), \mathrm{P}_{3} \mathrm{CN}: \mathrm{P}_{4} \mathrm{CN}(0.43), \mathrm{M}^{3} \mathrm{RN}: \mathrm{M}^{2} \mathrm{CN}(0.31)$, and $\mathrm{M}_{2} \mathrm{CN}: \mathrm{M}_{3} \mathrm{CN}(0.31)$, there are no significant correlations of $\mathrm{RN}$ to $\mathrm{CN}$ across different teeth. 


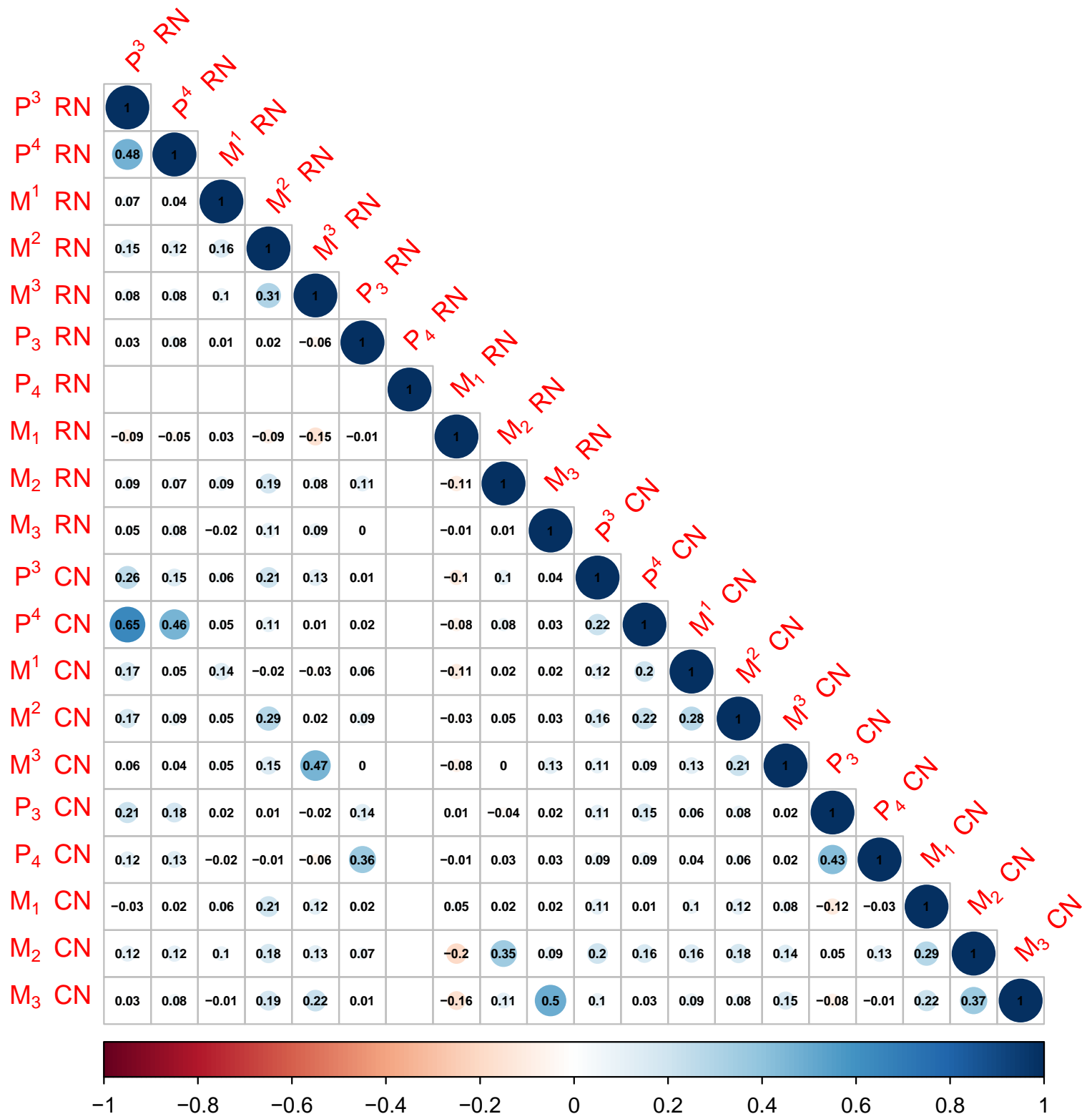

Figure 8: Pearson correlation of root number (RN) to canal number (CN). Significance level $=0.05$. Significant positive correlation coefficients in blue. Significant negative correlation coefficients in red. Blank cells in $\mathrm{P}_{4}$ $R N: P_{4} R N$ due to all $P_{4}$ s having the same level (i.e., one root. See Table 3).

\section{PGLM of relationship between canal and root number in individual teeth}

While independent variables are uncorrelated, uncorrelated variables are not always

411 independent. To address this, we fit PGLM with GEE to account for low levels of correlation

412 between some traits (Figure 8), and to account for using multiple teeth from the same

413 individuals, which may violate assumptions of variable independence. PGLM fitted with

414 PGEE was used to directly test the linear relationship of root to canal number by tooth - in

415 other words, to see how the relationship between canal and root number varies across 
different tooth types. PGLM of individual teeth reveal that for $M^{1}-M^{3}$, and $M_{1}-M_{3}$, as canal

417 count increases, so does root count (Table 5). In the maxilla, the greatest increase in root to

418 canal number is found in $\mathrm{M}^{1}(99.99 \%)$, and similar relationships are found in $\mathrm{M}^{2}$ and $\mathrm{M}^{3}$.

419 Maxillary premolars remain relatively stable, with a minimal increase $(0.03 \%)$ in $\mathrm{P}^{3}$, and no

420 increase in root number in $\mathrm{P}^{4}$. Mandibular molar $\left(\mathrm{M}_{1}-\mathrm{M}_{3}\right)$ roots are comparatively similar to

421 one another in their odds ratios, especially $\mathrm{M}_{1}$ and $\mathrm{M}_{2}$; while surprisingly, mandibular

422 premolars $\left(\mathrm{P}_{3}-\mathrm{P}_{4}\right)$ show that as canal number increases root number does not

423

Table 5. Regression parameters for PGLM and GEE regression of the association between canal-to-root number by tooth, ranked by odds ratios from greatest to least*

\begin{tabular}{lccccc}
\hline & Estimate & Odds ratio & Std. error & Wald & $P$-value \\
\hline $\begin{array}{l}\text { Canal number } \\
\text { Maxilla }\end{array}$ & 0.117 & 1.124 & 0.007 & 251.300 & $<.0001$ \\
$\mathrm{M}^{1}$ & & & & & \\
$\mathrm{M}^{3}$ & 0.693 & 1.999 & 0.025 & 750.400 & $<.0001$ \\
$\mathrm{M}^{2}$ & 0.650 & 1.916 & 0.025 & 683.700 & $<.0001$ \\
$\mathrm{P}^{3}$ & 0.648 & 1.911 & 0.025 & 651.900 & $<.0001$ \\
$\mathrm{P}^{4}$ & 0.000 & 1.000 & 0.018 & 0.000 & 0.990 \\
\multicolumn{1}{l}{ Mandible } & -0.091 & 0.913 & 0.011 & 69.100 & $<.0001$ \\
$\mathrm{M}_{3}$ & & & & & \\
$\mathrm{M}_{2}$ & 0.356 & 1.428 & 0.022 & 264.800 & $<.0001$ \\
$\mathrm{M}_{1}$ & 0.127 & 1.135 & 0.049 & 2.604 & $<.0001$ \\
$\mathrm{P}_{4}$ & 0.287 & 1.330 & 0.028 & 106.700 & $<.0001$ \\
$\mathrm{P}_{3}$ & -0.119 & 0.887 & 0.008 & 248.000 & $<.0001$ \\
\hline $\mathrm{M}$ & -0.127 & 0.881 & 0.008 & 236.100 & $<.0001$ \\
\hline
\end{tabular}

426

427

428

429

430

431

432

*Model fitted without intercept.

Prediction curves differ for each tooth, and the maxilla and mandible as a whole (Figure 9). Similar tooth groups have similar prediction curves $-P_{3}, P_{4}$, and $P^{4} ; M_{3}, M_{2}$, and $\mathrm{M}_{1}$; and $\mathrm{M}^{1}, \mathrm{M}^{2}, \mathrm{M}^{3}$; and these differ between the maxilla and mandible. As prediction curves diverge from the 1:1 canal-to-root ratio, root number decreases, though this does not necessitate a concomitant reduction in canal number (Figure 5). 


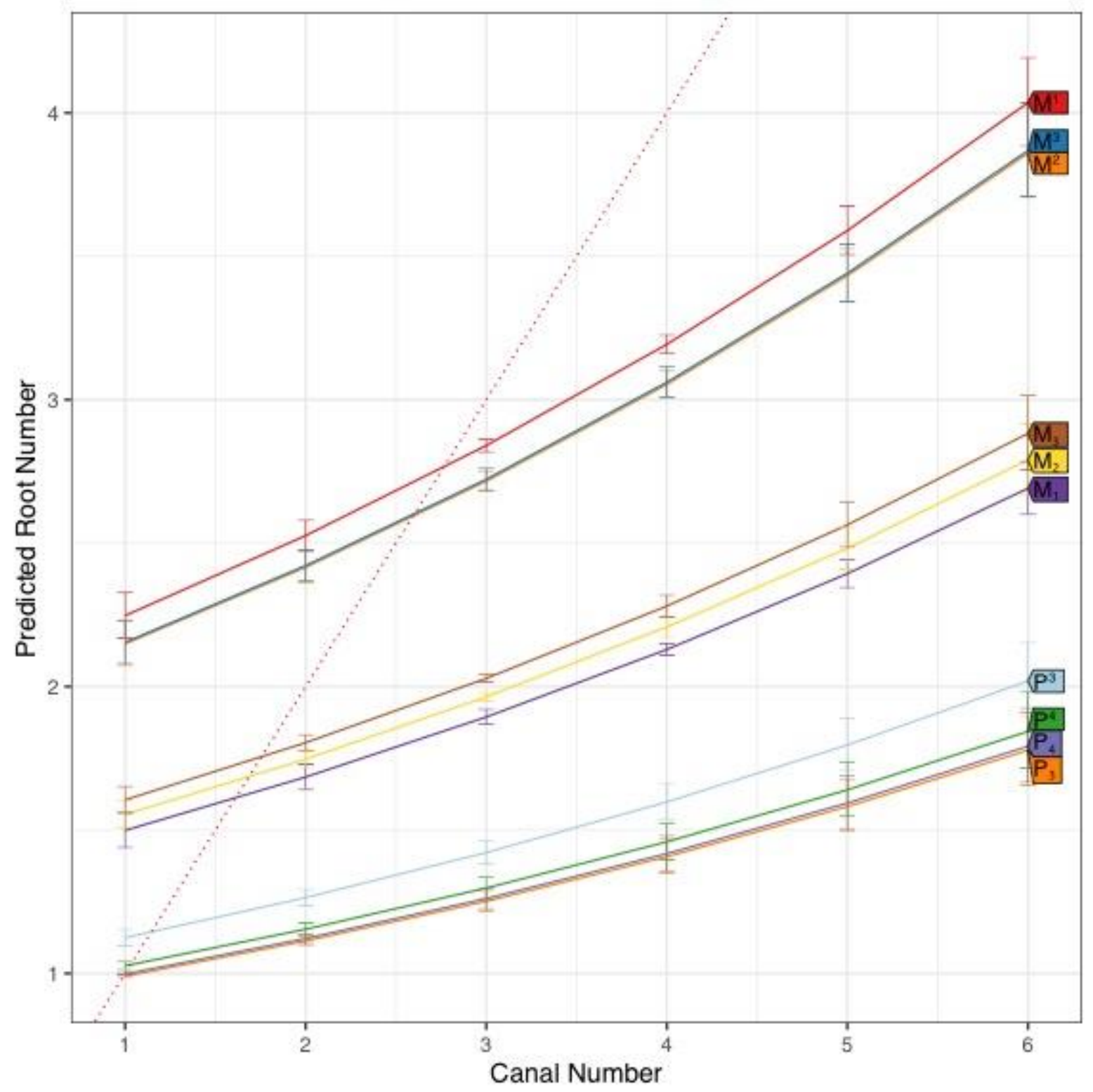

Figure 9: PGLM prediction curves with error bars for canal to root number for individual teeth. Dotted red line represents 1:1 canal to root relationship (i.e., what would be observed if there was a simple 1:1 relationship between roots and canals). Over prediction in the number of roots for single canaled $\mathrm{M}^{1} / \mathrm{M}_{1} \mathrm{~s}$ $\mathrm{M}^{3} / \mathrm{M}_{3} \mathrm{~S}$ is owing to very small sample of individuals with one root to one canal (see Table 3 for counts).

Figure 10 plots proportions of canal to root number of individual teeth within the sample. Different patterns are clearly evident across all teeth and between the maxilla and mandible and help to explain groupings of individual tooth prediction curves in Figure 9.

442 There is a slight over-prediction in the number of roots for single canaled $\mathrm{M}^{1}-\mathrm{M}^{3} \mathrm{~s}$ owing to

443 1) very small sample of individuals with one root to one canal for these teeth (see Table 3

444 for counts); and 2) because we have used a fixed non-parametric model to capture the non-

445 linearity between canal and root number. Variation in canal to root number decreases in the premolars while increasing in the molars, though this variation does not covary between 


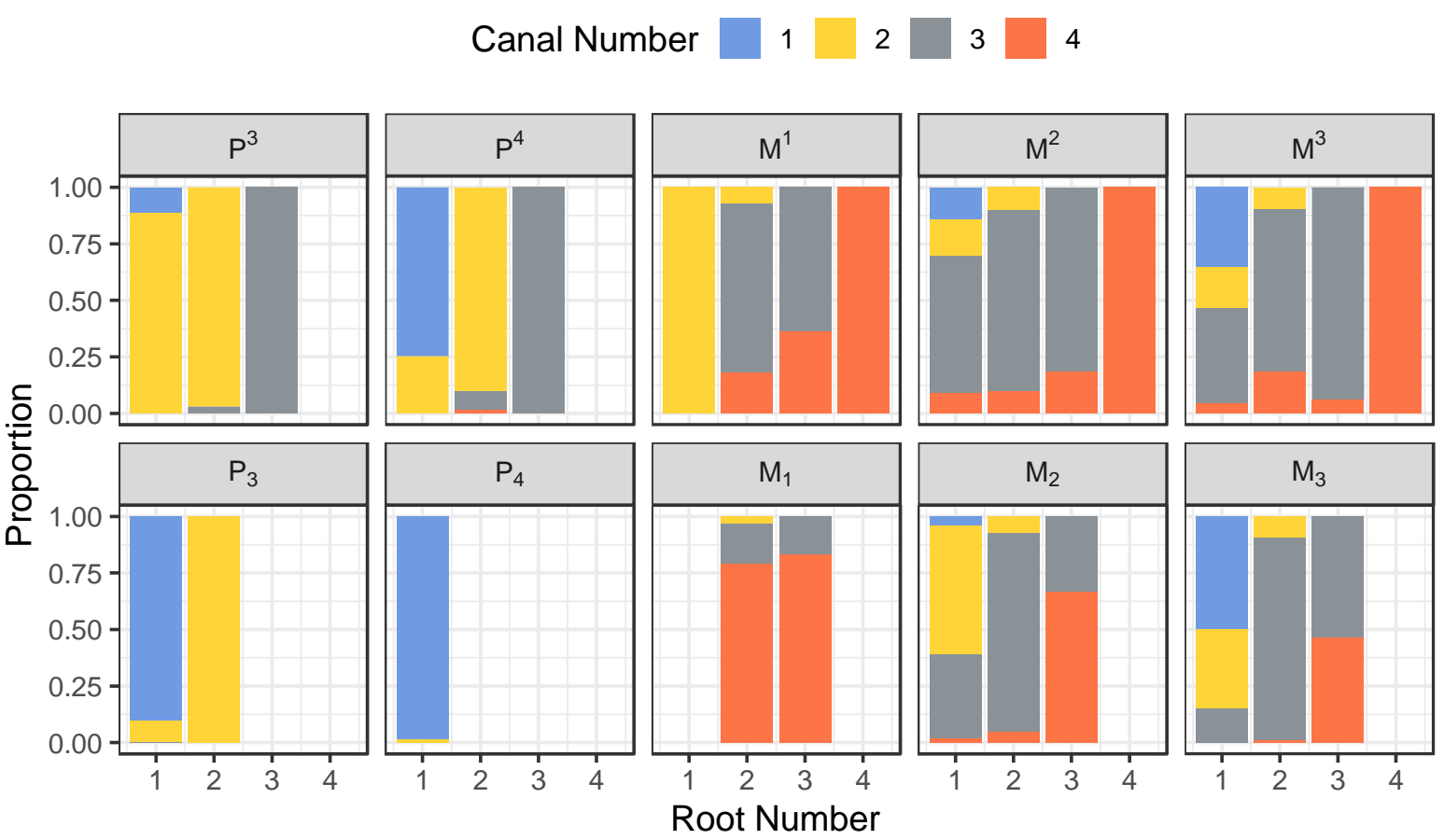

Figure 10: Proportion of canal to root number for individual teeth. 5 canaled teeth $=14,6$ canaled teeth $=2$, are included in calculations of proportions but are not visualized on this plot due to small sample size. and 10 reflect significant differences between teeth. Full statistical output is presented in the Supplementary Materials Table B. 
bioRxiv preprint doi: https://doi.org/10.1101/2022.02.01.478656; this version posted February 3, 2022. The copyright holder for this preprint (which was not certified by peer review) is the author/funder, who has granted bioRxiv a license to display the preprint in perpetuity. It is made available under aCC-BY-NC-ND 4.0 International license.

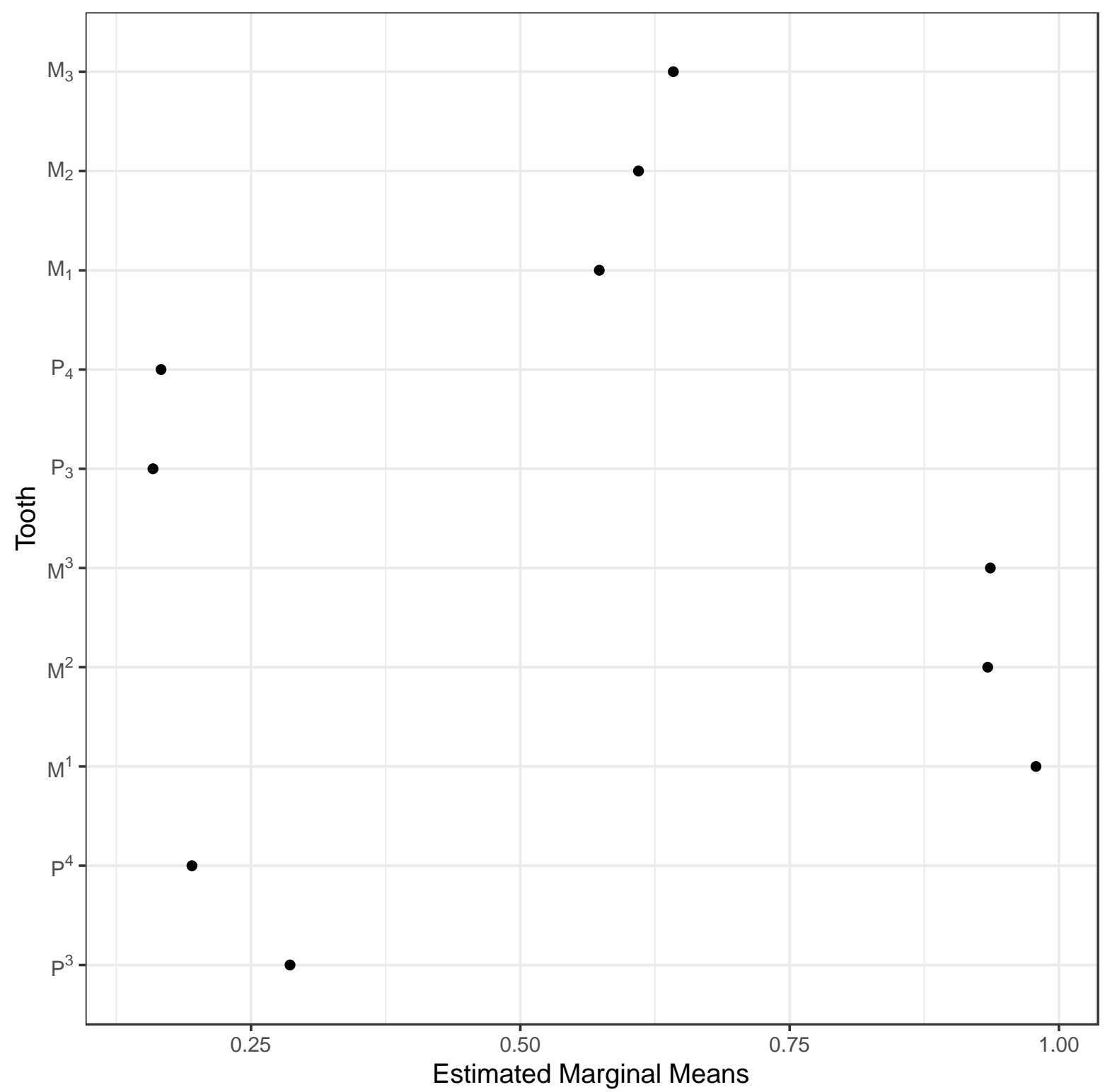

Figure 11: Estimated marginal means derived from Tukey pair-wise comparisons of canal to root number by tooth. Black dot= mean value; Blue bar = confidence intervals. The degree to which red comparison arrows overlap reflects the significance $(p=0.05)$ of the comparison of the two estimates. Full statistical output is presented in Supplementary Materials Table B.

We used PGLM to test the linear relationship of root to canal number by tooth across population groups (Table 6). To avoid emphasizing results against one geographical region or tooth we fitted the model without an intercept. 
bioRxiv preprint doi: https://doi.org/10.1101/2022.02.01.478656; this version posted February 3, 2022. The copyright holder for this preprint (which was not certified by peer review) is the author/funder, who has granted bioRxiv a license to display the preprint in perpetuity. It is made available under aCC-BY-NC-ND 4.0 International license.

471

472

Table 6: Regression parameters for the PGLM testing the association between canal and root number by tooth in geographic populations, ranked by odds ratio from greatest to least*.

\begin{tabular}{lccccc}
\hline \multicolumn{1}{c}{ Groups } & Estimate & Odds ratio & Std. error & Wald & $P$-value \\
\hline Canal number & 0.329 & 1.389 & 0.002 & 29139.9 & $<.0001$ \\
Sub-Saharan Africa & -0.211 & 0.810 & 0.007 & 816.8 & $<.0001$ \\
Sino-Americas & -0.235 & 0.790 & 0.006 & 1749.3 & $<.0001$ \\
Sunda-Pacific & -0.250 & 0.779 & 0.010 & 658.8 & $<.0001$ \\
West Eurasia & -0.238 & 0.789 & 0.007 & 1065.3 & $<.0001$ \\
Sahul-Pacific & -0.258 & 0.773 & 0.007 & 1206.2 & $<.0001$ \\
\hline
\end{tabular}

473

474

475

476

477

478

479

480

* Model fitted without intercept

Individual teeth of geographical groups are relatively similar in their odds ratios and prediction curves; and follow a similar pattern of divergence from a 1:1 canal-to-root ratio (Figure 12). Prediction curves for Sub-Saharan African populations are closest to the 1:1 canal-to-root ratio, while Sino-American populations are the furthest. While odds ratios of Sub-Saharan African and Sino-American populations are most similar, marginal effects quantify how both groups vary differently in their canal to root ratios (Figure 13).

- West Eurasia - Sahul-Pacific - Sino-Americas - Sub-Saharan Africa - Sunda-Pacific
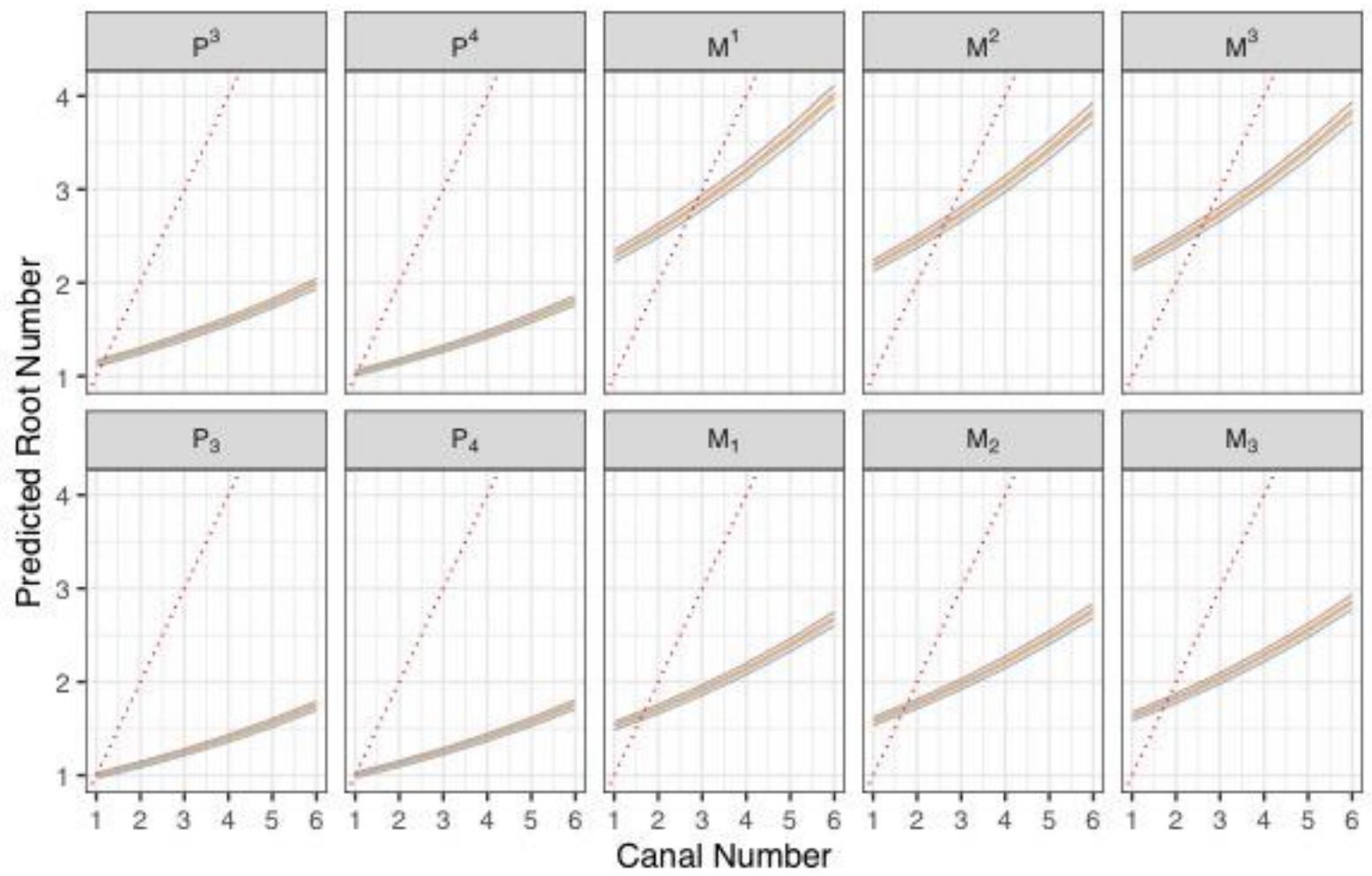
bioRxiv preprint doi: https://doi.org/10.1101/2022.02.01.478656; this version posted February 3, 2022. The copyright holder for this preprint (which was not certified by peer review) is the author/funder, who has granted bioRxiv a license to display the preprint in perpetuity. It is made available under aCC-BY-NC-ND 4.0 International license.

Figure 12: PGLM prediction curve for root to canal number by population. Dotted red line represents 1:1 root to canal relationship. Over prediction in the number of roots for single canaled $\mathrm{M}^{1} / \mathrm{M}_{1} \mathrm{~s}-\mathrm{M}^{3} / \mathrm{M}_{3} \mathrm{~s}$ is owing to very small sample of individuals with one root to one canal (see Table 3 for counts).

Marginal effects quantify how both groups vary differently in their canal to root ratios (Figure 13) when the explanatory variable (canals) changes by one unit. For all teeth, the Sino-American groups have the lowest percentage of change in root number as canal number increases, while Sub-Saharan Africans show a higher percentage of root number change as canal number increases.
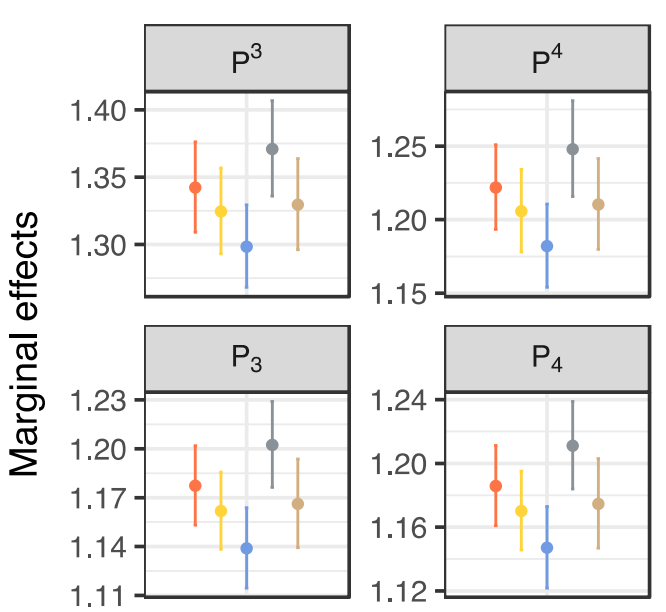

1.12

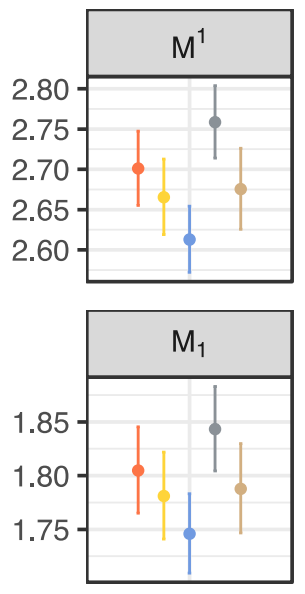

Region
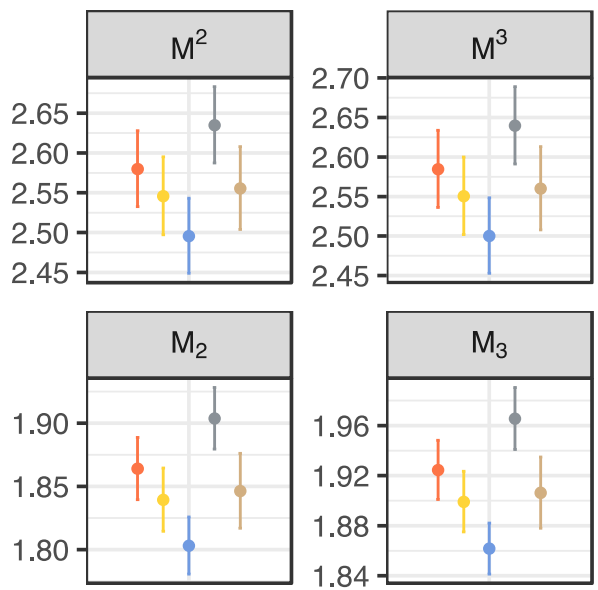

492

Figure 13: Marginal effects of canal to root count in individual teeth by geographical region.

Tukey pair-wise comparisons of PGLM of canal to root number by population show that patterns in prediction curves and marginal effects plotted in Figures 12 and 13 reflect significant differences between Sub-Saharan Africa and all other groups (Figure 14). Significant differences are also shown between Sahul-Pacific and Sino-Americans. Full statistical out is provided in Supplementary Materials Table C). 


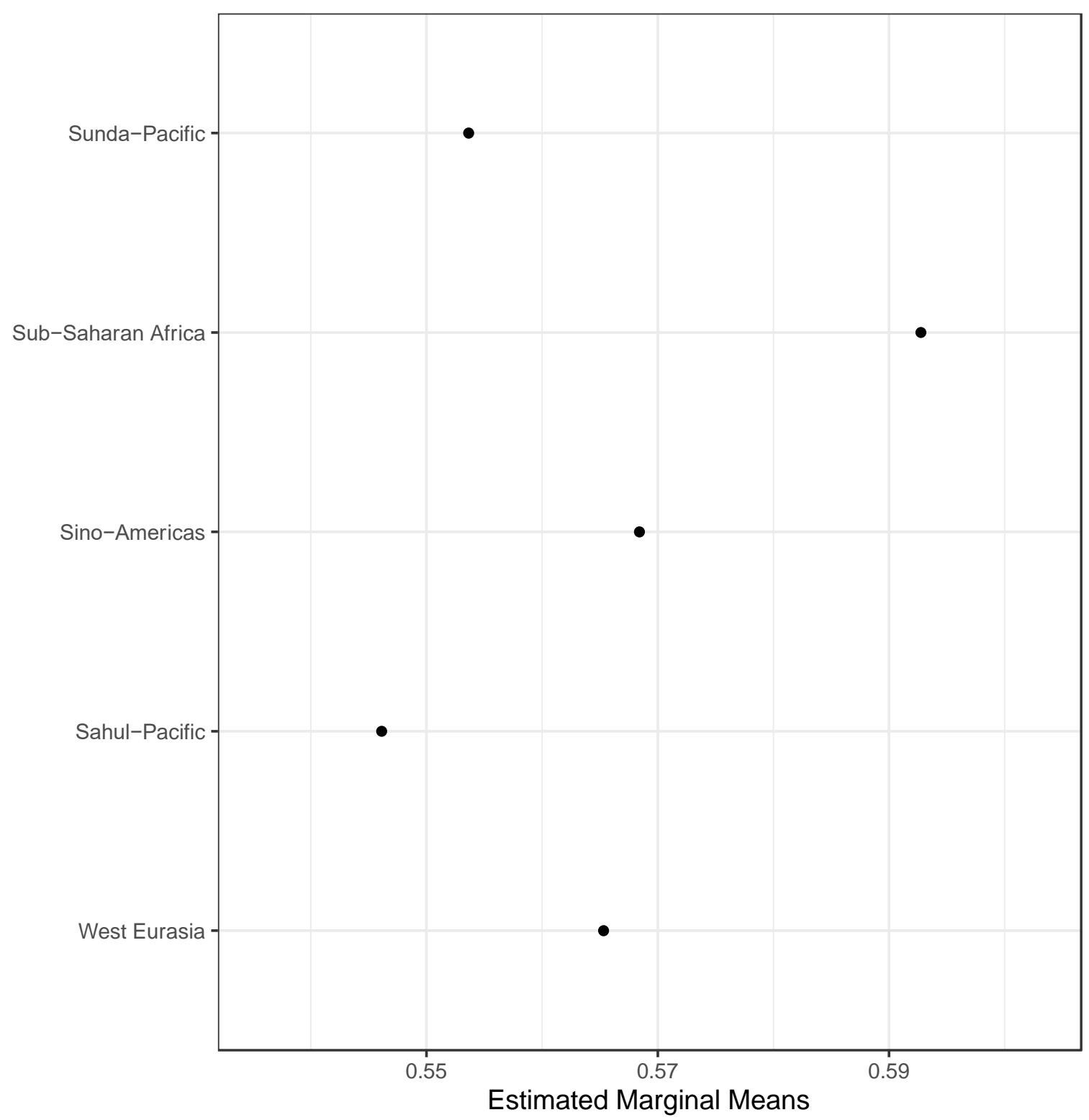

Estimated Marginal Means

Figure 14: Estimated marginal means derived from Tukey pair-wise comparisons of PGLM of canal to root number by geographical region. Black dot= mean value; Blue bar = confidence intervals. The degree to which red comparison arrows overlap reflects the significance $(p=0.05)$ of the comparison of the two estimates. Full statistical output is presented in Supplementary Materials Table C.

\section{Discussion}

In the analyses presented above we have been able to show that there is little to no

510 correlation between root and canal number in teeth (Figure 8). However, because

511 uncorrelated random variables are not always independent, we extended our PGLM with

512 GEE to develop a predictive model of the relationship between canal and root number,

513 globally and by region, and we show that this relationship is not perfectly linear. We have

514 found that canal number predicts root number, and that the greater the number of canals 
515

516

517

518

519

520

521

522

523

524

525

526

527

528

529

530

531

532

533

534

535

536

537

538

539

540

541

542

543

544

the more complex, and less predictable the number of roots. This relationship varies by maxillary and mandibular teeth and tooth row. These results raise a number of issues: what does the complexity of canal to root number relationships mean developmentally? Why does this complexity vary across particular tooth types? How does divergence in canal and root number vary between maxillary and mandibular teeth in total, by population, and individually?

\section{Differences in root and canal number}

Currently, there is no consensus as to why canals and roots should differ in number, given that canal formation precedes root formation. Clusters of blood vessels entering the dental papilla early in tooth formation coincide with the positions where roots will eventually form (Nanci, 2012). The HERS and expanding dental pulp form around these nerves and blood vessels before dentin formation. Thus, each root must contain at least one canal for the pulp, and the nerve and blood supply that precede the formation of the surrounding root structure. It is possible that number, size, and configuration of blood and nerve supplies is, in part, responsible for variation in canal number with the roots, and not variation in the number and orientation of the interradicular processes alone.

\section{Variance across teeth and between the maxilla and mandible}

Why canal and root number should vary both within and between teeth of the maxilla and mandible is also unknown. Prediction curves and proportions of canal to root numbers show that the relationship between canals and roots within tooth types are similar to one another, i.e., maxillary molars are alike, while being significantly different from other tooth types, i.e., such as premolars and mandibular molars. Similar estimates (Table 5) and PGLM curves of tooth types (Figure 9) seem to lend support to the morphogenetic field model in which teeth within a field are more similar to one another than to teeth of another field (Butler, 1937, 1963; Dahlberg, 1945); especially for molar fields in both jaws. These results suggest that the number of canals and roots within tooth types are relatively "fixed" with little intra-tooth type variation. We propose two possible explanations, the first functional, the second spatial. 

Abbott, 1983; Reed, 1997; Wood and Constantino, 2007); and heavy chewing requires large teeth. The majority of chewing actions occur on the broad occlusal surfaces of the postcanine teeth where, compared to anterior teeth, masticatory movements are complex combinations of antero-posterior, vertical and lateral movements (van Eijden, 1991; Ledogar et al., 2016). Chewing pressures on the maxillary teeth result from absorption of shearing and compressive forces generated by the active movement of the mandible (Ledogar et al., 2016). During mastication, maxillary molars are subjected to greater mediolateral directed loads than mandibular molars (Dempster et al., 1963; Spears and Macho, 1998). These medio-lateral forces are dissipated into the jaws via the tooth roots (Nikolai and Zwemer, 1985; Baragar and Osborn, 1987); and, in humans, are strongest at, and decrease posteriorly from $\mathrm{M}^{1} / \mathrm{M}_{1} \mathrm{~S}$ (Gordon, 1984; Macho and Spears, 1999). Consequently, as root surface area decreases in $\mathrm{M}^{2}$ and $\mathrm{M}^{3}$, so does root number ((Dempster et al., 1963); Table 3).

It is possible that where increased masticatory loadings are a selective pressure for larger teeth, an increased blood supply required for developing a larger tooth will result in an increase in canal number. This will, in turn, result in more roots. The increased mesiodistal and bucco-lingual dimensions of premolars tooth crowns belonging to megadontic "robust australopiths" (Paranthropus boisei, P. robustus, P. aethiopicus), support such as hypothesis. These "hyper-robust" hominins regularly had multi-rooted/canaled premolars (Robinson, 1954, 1956; Wood et al., 1988b; Brook et al., 2014; Moore et al., 2016; Kupczik et al., 2018), and the ancestral hominin phenotype has been proposed as three-root maxillary premolars, and two-root mandibular premolars In modern humans, molars withstand the heaviest masticatory loadings while premolars are subjected to the least (Demes and Creel, 1988; Ledogar et al., 2016). That masticatory stresses produce high strains in the alveolar margin of the anterior maxilla (Ledogar et al., 2016) may act to increase canal and root number in the maxillary premolars compared to mandibular premolars. Developmentally, Shields (2005) proposed that tooth germ size influenced the number and development of IRP's. However, multiple studies have noted that tooth crown

574 size (used as proxy for tooth germ size) does not always covary with root number and size in humans and hominoids (Abbot, 1984; Shields, 2005; Moore et al., 2013, 2016). 
Different masticatory forces resulting from dietary demands have been shown to

577 increase tooth root surface area, and thus size, in primates (Kovacs, 1971; Spencer, 2003;

578 Kupczik and Dean, 2008; Ledogar et al., 2016). A possible selective mechanism to increase

579 tooth root surface area would be to increase the number of roots, which would in turn

580 enlarge the cervical base area of the crown (Kupczik et al., 2005). A study of Gorilla gorilla,

581 Pan troglodytes, as well as of 26 fossil gracile and robust hominins from South Africa concluded that dietary adaptations produced mesio-distal expansion at the base of tooth roots in $\mathrm{M}^{1} \mathrm{~s}$ (Kupczik et al., 2018). The authors (ibid) concluded that it was increases in root splay that accommodated higher masticatory loadings, but that the mesio-distal expansion of the root bases in robust hominins might be an adaptive response to different jaw kinematics for chewing different food types - horizontally directed repetitive chewing in $P$. boisei (Demes and Creel, 1988; Wood and Constantino, 2007), versus multi- directional loading of $P$. robustus (Macho, 2015). However, the extant and fossil species from this study are already characterized by multi rooted molars and premolars (Sperber, 1973; Wood et al., 1988a; Kupczik et al., 2005; Shields, 2005); so it is difficult to discern if mesio-distal expansion of the roots is an adaptive response to biomechanical pressures, a bi-product of additional roots, or both. If root splay is in fact the primary adaptive response to increased masticatory loading, the selective pressures underlying what point single root surface area/size stops increasing and root differentiation begins have yet to be elucidated.

Alternatively, variation may arise from space required for growing teeth in the developing jaws. Consider that maxillary and mandibular 1st molars are the first adult teeth to erupt (at 6-7 years) followed by the anterior teeth (7-10 years), premolars (10-12 years), followed by 2 nd (12-13 years) and 3rd molars (17-21 years). In this spatial scenario maxillary and mandibular 1st molars have the greatest number of roots and canals, while late-forming and erupting premolars have the least as they are sandwiched between 1st molars and the already erupted anterior teeth. Constrained variation, especially in the premolars may be explained by limited space for growth and development, while maxillary and mandibular molars have spatial restrictions on their growth and development limited by dimensions of the palate and by the ascending ramus of the mandible. 
608

609

610

611

612

613

614

615

616

617

618

619

620

621

622

623

624

625

626

627

628

629

630

631

632

633

634

635

636

637

in early human evolutionary history. Premolar root number has been documented as more variable than in all other tooth types (Sperber, 1973; Wood et al., 1988a; Kupczik et al., 2005; Shields, 2005). Contrary to the molarization of the robust Paranthropines, the reduction of premolar root number is present in South-African gracile hominins. Robinson (1956) and Sperber (1974) report predominantly (84\%) double-rooted maxillary premolars in a sample of Australopithecus africanus, though single (8\%) and triple-rooted (8\%) variants do occur. A. africanus mandibular premolars are reported as having single C-shaped (also referred to as Tomes' root) and double-rooted mandibular molars (Robinson 1952, 1956; Sperber, 1974, Moore et al.,2016). Thus, this trend for reduction in premolar root number appears early in human evolutionary history (3.4 -2.4 Ma) and coincides with dietary shifts towards meat and/or softer cooked foods (Luca et al., 2010), and reduction of hominin tooth crowns, jaws and face. At $1.8 \mathrm{Ma}$ Homo erectus has fewer tooth roots, especially $\mathrm{M}_{3}{ }^{\prime}$, than earlier members of our genus, and $H$. erectus premolars are frequently single rooted (Antón, 2003). This trend in root number reduction continues through more recent members of Genus Homo including some specimens allocated to $H$. heidelbergensis and $H$. neanderthalensis (Benazzi et al., 2011; Martinón-Torres et al., 2012; Zanolli and Mazurier, 2013).

\section{Differences in geographical groups}

Sino-American and Sub-Saharan African populations are significantly different from one another (Figure 11, Supplementary Materials Table C), and these differences can be explained by reduction in root number in the former. Compared to all other groups, SinoAmericans have the greatest proportion of single rooted teeth across all populations while Sub-Saharan African populations have the smallest (Figure 10). This trend is present regardless of canal number. The exception to this is the presence of three-rooted mandibular molars (ento- and para-molaris root forms) in Sino-Americans (Carlsen and Alexandersen, 1990). This form represents a relatively rare polymorphism, and appears with frequencies around 30-50\% in East Asian, Inuit, and Aleut populations; 5-15\% in Southeast Asian and Pacific populations; compared to $1 \%$ in European and Sub-Saharan African populations (Scott et al., 2018). 
As with tooth types, there is no clear explanation for changes in canal to root number between populations. The reasons may be biomechanical in nature and relate to different diets between populations. However, this is unlikely as the Sino-American populations included in this study (primarily comprised of North American First peoples; see Figure 4 \& Supplementary Materials Table C), did not pursue uniform subsistence strategies. However, the effect of different diets on tooth root and canal morphologies is poorly understood, with only a few studies centred on non-human primates, and gracile and robust Australopiths (see Kupczik et al., 2018 for an overview).

The study of dental traits have an extensive history and utility for characterizing and assessing the biological relationships within and populations (see Scott et al., 2018 for a comprhensive review). Dental morphology has been shown to be under strong genetic control and minimally affected by environmental factors (Corruccini et al., 1986; Dempsey and Townsend, 2001). The evolutionary trend of teeth has also been described as towards reduction in size and simplification in morphology (Scott and Turner II, 1988). While the authors of these studies were describing tooth crowns, tooth roots are presumably operating under the same genetic and environmental constraints, and evolutionary trends. simplification in terms of reduction. Sub-Saharan Africans and Sino-Americans are furthest in distance from one another in time and space, and the former group shows the greatest variation in root and canal number, while the latter shows a reduction. For example, SinoAmericans have a higher proportion of single rooted, double-canaled $M_{2}$ 's and $M_{3}$ 's than all other groups. Additionally, congenitally absent $\mathrm{M}_{3}$ 's are common (>25\%) in Sino-American populations (Turner II et al., 1991; Daito et al., 1992; Rakhshan, 2015; Scott et al., 2018). Compared to Sub-Saharan African populations, Western Eurasia, Sahul- and Sunda-Pacific groups have reduced variability, though not as much as Sino-Americans. These three groups share similar linear relationships (Figure 8) and canal to root proportions (Figure 10), though marginal means of West Eurasian and Sunda-Pacific populations reveal their canal to root relationships are more similar to Sub-Sharan Africa, while Sahul-Pacific is closer to SinoAmericas. 
670

671

672

673

674

675

676

677

678

679

680

681

682

683

684

685

686

687

688

689

690

691

692

693

694

695

696

697

698

699

700

anatomically modern humans. Reduced intra-population diversity has been ascribed to an "Out of Africa" migration, and sequence of founder events due to rapid expansions and colonization of the world (Prugnolle et al., 2005; Liu et al., 2006; Li et al., 2008). This reduction in diversity has been recorded in human dental (Hanihara and Ishida, 2005; Hanihara, 2008), craniofacial (Hanihara and Ishida, 2009; Betti et al., 2012), and morphometric traits (Manica et al., 2007), further supporting genetic hypotheses of this single, African origin and subsequent expansions. However, some exceptions to this exist. For example, three rooted $\mathrm{M}_{1}$ 's, sometime referred to as Radix entomolaris (see Calberson, De Moor and Deroose, 2007 for a review), increase in Sino-American populations while appearing in low frequency in other populations; especially Sub-Saharan Africa (Scott et al., 2018). This trait has been most commonly attributed to genetic drift (Scott et al., 2018), though a recent study has suggested archaic introgression (Bailey et al., 2019); however, see Richard Scott, Irish and Martinón-Torres (2020) for a rebuttal.

\section{Conclusion}

This paper presents a novel investigation into the relationship between canal and root number in human post-canine teeth. In all cases, canal number is either equal to or exceeds root number, supporting our hypothesis that canal number precedes and is, in part, responsible for root number in all post-canine teeth. These canal to root relationships are significantly different between tooth types (i.e., molars and premolars), within and between the maxilla and mandible. Results indicate that Sub-Sharan African and Sino-American populations are significantly different in their canal to root numbers, and this difference represents an overall reduction in root number with distance from Africa, but not necessarily canal number. Canal to root relationships differ across all populations studied, however the reasons for these differences are not ultimately clear. To test population affinities and differences, future studies should include morphological distance-based analysis to test divergence, as well as consider additional biological, historical, linguistic and cultural data. Results also show that tooth types within and between the jaws have different linear relationships and that these relationships are significantly different. These results support biomechanical and spatial hypotheses related to tooth crown size in hominin evolution, and future studies should include root and canal count in their analysis. 
701

702

703

704

705

706

707

708

709

710

711

712

713

714

715

716

717

718

719

720

721

722

723

724

725

726

727

728

729

730

\section{Acknowledgements}

We would like to thank Professor Marta Miraźon-Lahr and Dr. Frances Rivera for permitting use of their CT scans from the Duckworth Collection at the Leverhulme Centre for Human Evolutionary Studies, University of Cambridge; and Dr. Lynn Copes for permitting use of her CT scans, collected for her PhD dissertation, from the Smithsonian National Museum of Natural History and American Museum of Natural History, and the editors and reviewers for their feedback. We thank the Duckworth Laboratory, University of Cambridge, for permission to study material within its collections. We would also like to thank $\mathrm{Dr}$. Christopher N. Foley for assistance and feedback on our statistical analyses; and Friederike Jürcke for assistance with Figures $2 \& 5$.

\section{Author contributions}

Concept and design by Jason Gellis and Robert Foley. Acquisition of data and data analysis by Jason Gellis. Drafting of the manuscript by Jason Gellis and Robert Foley. Revision of the manuscript by Jason Gellis.

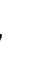

(1)


731

732

733

734

735

736

737

738

739

740

741

742

743

744

745

746

747

748

749

750

751

752

753

754

755

756

757

758

759

760

761

\section{References}

Ackerman, J.L., Ackerman, A.L., Ackerman, A.B., 1973. Taurodont, pyramidal and fused molar roots associated with other anomalies in a kindred. American Journal of Physical Anthropology. 38, 681-694.

Agresti, A., 2002. Categorical Data Analysis. Somerset: John Wiley \& Sons, Incorporated, Somerset.

Ahmed, H.M.A., Versiani, M.A., De-Deus, G., Dummer, P.M.H.H., 2017. A new system for classifying root and root canal morphology. International Endodontic Journal. 50, 761770.

Akoglu, H., 2018. User's guide to correlation coefficients. Turkish Journal of Emergency Medicine.

Antón, S.C., 2003. Natural History of Homo erectus. American Journal of Physical Anthropology. 122, 126-170.

Bailey, S.E., Hublin, J.J., Antón, S.C., 2019. Rare dental trait provides morphological evidence of archaic introgression in Asian fossil record. Proceedings of the National Academy of Sciences of the United States of America. 116, 14806-14807.

Baragar, F.A., Osborn, J.W., 1987. Efficiency as a predictor of human jaw design in the sagittal plane. Journal of Biomechanics. 20, 447-457.

Benazzi, S., Viola, B., Kullmer, O., Fiorenza, L., Harvati, K., Paul, T., Gruppioni, G., Weber, G.W., Mallegni, F., 2011. A reassessment of the Neanderthal teeth from Taddeo cave (southern Italy). Journal of Human Evolution. 61, 377-387.

Betti, L., Balloux, F., Amos, W., Hanihara, T., Manica, A., 2012. Distance from Africa, not climate, explains within-population phenotypic diversity in humans. Proceedings of the Royal Society B: Biological Sciences. 276, 809-814.

Blattner, T.C., George, N., Lee, C.C., Kumar, V., Yelton, C.D.J., 2010. Efficacy of Cone-Beam Computed Tomography as a Modality to Accurately Identify the Presence of Second Mesiobuccal Canals in Maxillary First and Second Molars: A Pilot Study. Journal of Endodontics. 36, 867-870.

Brook, A.H., Jernvall, J., Smith, R.N., Hughes, T.E., Townsend, G.C., 2014. The dentition: The outcomes of morphogenesis leading to variations of tooth number, size and shape. Australian Dental Journal. 59, 131-142. 
762

763

764

765

766

767

768

769

770

771

772

773

774

775

776

777

778

779

780

781

782

783

784

785

786

787

788

789

790

791

792

793

Butler, P.M., 1937. Studies of the Mammalian Dentition. I. The Teeth of Centetes ecaudatus and its Allies. Proceedings of the Zoological Society of London. 107 B, 103-132.

Butler, P.M., 1963. Tooth morphology and primate evolution. In: Brothwell, D.R. (Ed.), Dental Anthropology. Pergamon Press, New York, pp. 1-13.

Calberson, F.L., De Moor, R.J., Deroose, C.A., 2007. The Radix Entomolaris and Paramolaris: Clinical Approach in Endodontics. Journal of Endodontics. 33, 58-63.

Carlsen, O., Alexandersen, V., 1990. Radix entomolaris: identification and morphology. Scandinavian Journal of Dental Research. 98, 363-73.

Cavalli-Sforza, L.L., 1994. The History and Geography of Human Genes. Princeton : Princeton University Press, 1994., Princeton.

Corruccini, R.S., Sharma, K., Potter, R.H.Y., 1986. Comparative genetic variance and heritability of dental occlusal variables in U.S. and Northwest Indian twins. American Journal of Physical Anthropology. 70, 293-299.

Dahlberg, A.A., 1945. The Changing Dentition of Man. The Journal of the American Dental Association. 32, 676-690.

Daito, M., Tanaka, T., Hieda, T., 1992. Clinical observations on the development of third molars. Journal of Osaka Dental University. 26, 91-104.

De Pablo, Ó.V., Estevez, R., Péix Sánchez, M., Heilborn, C., Cohenca, N., 2010. Root anatomy and canal configuration of the permanent mandibular first molar: A systematic review. Journal of Endodontics.

Demes, B., Creel, N., 1988. Bite force, diet, and cranial morphology of fossil hominids. Journal of Human Evolution. 17, 657-670.

Dempsey, P.J., Townsend, G.C., 2001. Genetic and environmental contributions to variation in human tooth size. Heredity. 86, 685-693.

Dempster, W.T., Adams, W.J., Duddles, R.A., 1963. Arrangement in the jaws of the roots of the teeth. Journal of the American Dental Association. 67, 779-797.

Diggle, P., Heagerty, P., Liang, K.-Y., Zeger, S., 2002. Analysis of Longitudinal Data. Oxford: Oxford University Press, Incorporated, Oxford.

Domark, J.D., Hatton, J.F., Benison, R.P., Hildebolt, C.F., 2013. An ex vivo comparison of digital radiography and cone-beam and micro computed tomography in the detection of the number of canals in the mesiobuccal roots of maxillary molars. Journal of Endodontics. 39, 901-905. 
Emonet, E.G., Tafforeau, P., Chaimanee, Y., Guy, F., de Bonis, L., Koufos, G., Jaeger, J.J., 2012. Three-dimensional analysis of mandibular dental root morphology in hominoids. Journal of Human Evolution. 62, 146-154.

Fischischweiger, W., Clausnitzer, E., 1988. Root formation in molar teeth of the CD-1 mouse. Journal of Endodontics. 14, 163-168.

Fu, Q., Posth, C., Hajdinjak, M., Petr, M., Mallick, S., Fernandes, D., Furtwängler, A., Haak, W., Meyer, M., Mittnik, A., Nickel, B., Peltzer, A., Rohland, N., Slon, V., Talamo, S., Lazaridis, I., Lipson, M., Mathieson, I., Schiffels, S., Skoglund, P., Derevianko, A.P., Drozdov, N., Slavinsky, V., Tsybankov, A., Cremonesi, R.G., Mallegni, F., Gély, B., Vacca, E., Morales, M.R.G., Straus, L.G., Neugebauer-Maresch, C., Teschler-Nicola, M., Constantin, S., Moldovan, O.T., Benazzi, S., Peresani, M., Coppola, D., Lari, M., Ricci, S., Ronchitelli, A., Valentin, F., Thevenet, C., Wehrberger, K., Grigorescu, D., Rougier, H., Crevecoeur, I., Flas, D., Semal, P., Mannino, M.A., Cupillard, C., Bocherens, H., Conard, N.J., Harvati, K., Moiseyev, V., Drucker, D.G., Svoboda, J., Richards, M.P., Caramelli, D., Pinhasi, R., Kelso, J., Patterson, N., Krause, J., Pääbo, S., Reich, D., 2016. The genetic history of Ice Age Europe. Nature. 534, 200-205.

Garson, G.D., 2015. Missing values analysis and data imputation, Statistical Associates Publishers.

Gellis, J.J., Foley, R.A., 2021. A novel system for classifying tooth root phenotypes. PLOS ONE. 16, e0251953.

Gordon, K.R., 1984. Microfracture patterns of abrasive wear striations on teeth indicate directionality. American Journal of Physical Anthropology. 63, 315-322.

Halekoh, U., Højsgaard, S., Yan, J., 2006. The R package geepack for generalized estimating equations. Journal of Statistical Software. 15, 1-11.

Handley, L.J.L., Manica, A., Goudet, J., Balloux, F., 2007. Going the distance: human population genetics in a clinal world. Trends in Genetics. 23, 432-439.

Hanihara, T., 2008. Morphological variation of major human populations based on nonmetric dental traits. American Journal of Physical Anthropology. 136, 169-182.

Hanihara, T., 2013. Geographic structure of dental variation in the major human populations of the world. In: Anthropological Perspectives on Tooth Morphology. Cambridge University Press, pp. 479-509.

Hanihara, T., Ishida, H., 2005. Metric dental variation of major human populations. 
Hanihara, T., Ishida, H., 2009. Regional differences in craniofacial diversity and the population history of Jomon Japan. American Journal of Physical Anthropology. 139, $311-322$.

830

Hoffmann, J.P., 2004. Generalized linear models : an applied approach, Generalized linear models : an applied approach. Pearson A and B, Boston ; London.

Hsu, Y.Y., Kim, S., 1997. The resected root surface. The issue of canal isthmuses. Dental clinics of North America. 41, 529-540.

https://www.horosproject.org, 2016. Horos Dicom Viewer.

Irish, J.D., 1998. Ancestral dental traits in recent Sub-Saharan Africans and the origins of modern humans. Journal of Human Evolution. 34, 81-98.

Jernvall, J., Thesleff, I., 2000. Reiterative signaling and patterning during mammalian tooth morphogenesis. Mechanisms of Development. 92, 19-29.

Josse, J., Husson, F., 2016. missMDA: A package for handling missing values in multivariate data analysis. Journal of Statistical Software. 70.

Kovacs, I., 1971. A Systematic Description of Dental Roots. In: Dental Morphology and Evolution. pp. 211-256.

Kupczik, K., Dean, M.C., 2008. Comparative observations on the tooth root morphology of Gigantopithecus blacki. Journal of Human Evolution. 54, 196-204.

Kupczik, K., Hublin, J.J., 2010. Mandibular molar root morphology in Neanderthals and Late Pleistocene and recent Homo sapiens. Journal of Human Evolution. 59, 525-541.

Kupczik, K., Olejniczak, A.J., Skinner, M.M., Hublin, J.J., 2009. Molar crown and root size relationship in anthropoid primates. In: Frontiers of Oral Biology. pp. 16-22.

Kupczik, K., Spoor, F., Pommert, A., Dean, M., 2005. Premolar root number variation in hominoids: genetic polymorphism vs. functional significance. In: Current Trends in Dental Morphology Research. pp. 257-268.

Kupczik, K., Toro-Ibacache, V., Macho, G.A., 2018. On the relationship between maxillary molar root shape and jaw kinematics in Australopithecus africanus and Paranthropus robustus. Royal Society Open Science. 5.

Larsen, H.E., Rainey, F.G., 1948. Ipiutak and the Arctic whale hunting culture.

857 Le Cabec, A., Gunz, P., Kupczik, K., Braga, J., Hublin, J.J., 2013. Anterior tooth root 
morphology and size in Neanderthals: Taxonomic and functional implications. Journal of Human Evolution. 64, 169-193.

Ledogar, J.A., Dechow, P.C., Wang, Q., Gharpure, P.H., Gordon, A.D., Baab, K.L., Smith, A.L., Weber, G.W., Grosse, I.R., Ross, C.F., Richmond, B.G., Wright, B.W., Byron, C., Wroe, S., Strait, D.S., 2016. Human feeding biomechanics: Performance, variation, and functional constraints. PeerJ. 2016.

Li, J., Parada, C., Chai, Y., 2017. Cellular and molecular mechanisms of tooth root development. Development (Cambridge). 144, 374-384.

Li, J.Z., Absher, D.M., Tang, H., Southwick, A.M., Casto, A.M., Ramachandran, S., Cann, H.M., Barsh, G.S., Feldman, M., Cavalli-Sforza, L.L., Myers, R.M., 2008. Worldwide human relationships inferred from genome-wide patterns of variation. Science. 319, 11001104.

Liu, H., Prugnolle, F., Manica, A., Balloux, F., 2006. A geographically explicit genetic model of worldwide human-settlement history. American Journal of Human Genetics. 79, 230237.

Luca, F., Perry, G.H., Di Rienzo, A., 2010. Evolutionary Adaptations to Dietary Changes. Annual Review of Nutrition. 30, 291-314.

Luder, H.U., 2015. Malformations of the tooth root in humans. Frontiers in Physiology. 6, 307.

Macho, G.A., 2015. Trends in Biological Anthropology, 1st ed. Oxbow, Oxford.

Macho, G.A., Spears, I.R., 1999. Effects of loading on the biochemical behavior of molars of Homo, Pan, and Pongo. American Journal of Physical Anthropology. 109, 211-227.

Manica, A., Amos, W., Balloux, F., Hanihara, T., 2007. The effect of ancient population bottlenecks on human phenotypic variation. Nature. 448, 346-348.

Manning, S.A., 1990. Root canal anatomy of mandibular second molars: Part II C-shaped canals. International Endodontic Journal. 23, 40-45.

Maret, D., Peters, O.A., Galibourg, A., Dumoncel, J., Esclassan, R., Kahn, J.L., Sixou, M., Telmon, N., 2014. Comparison of the accuracy of 3-dimensional cone-beam computed tomography and micro-computed tomography reconstructions by using different voxel sizes. Journal of endodontics. 40, 1321-1326. 

anatomy. In: The Root Canal Anatomy in Permanent Dentition. Springer International Publishing, pp. 89-180.

Michetti, J., Maret, D., Mallet, J.P., Diemer, F., 2010. Validation of cone beam computed tomography as a tool to explore root canal anatomy. Journal of Endodontics. 36, 11871190.

Mirazón-Lahr, M., 2011. A Brief History of the Duckworth Collections [WWW Document]. URL https://www.human-evol.cam.ac.uk/history.html (accessed 12.20.21).

Moore, C.N., Hublin, J.J., Skinner, M.M., 2015. Premolar root and canal variation in extant non-human hominoidea. American Journal of Physical Anthropology. 158, 209-226.

Moore, C.N., Skinner, M.M., Hublin, J.J., 2013. Premolar root morphology and metric variation in Pan troglodytes verus. American Journal of Physical Anthropology. 150, $632-646$.

Moore, C.N., Thackeray, J.F., Hublin, J.J., Skinner, M.M., 2016. Premolar root and canal variation in South African Plio-Pleistocene specimens attributed to Australopithecus africanus and Paranthropus robustus. Journal of Human Evolution. 93, 46-62. cross-societal study. The Journal of Developmental Processes. 5969. measurement error in a clustered cross-sectional survey. RMS: Research in Mathematics \& Statistics. 8.

Nanci, A., 2012. Ten Cate's oral histology, 8th edition, BDJ.

Nelson, S.J., Ash, M.M., 2010. Wheeler's dental anatomy, physiology, and occlusion. Saunders/Elsevier.

Nichol, C.R., Turner II, C.G., Dahlberg, A.A., 1984. Variation in the convexity of the human maxillary incisor labial surface. American Journal of Physical Anthropology. 63, 361370.

Nikolai, R.J., Zwemer, T., 1985. Bioengineering analysis of orthodontic mechanics. American Journal of Orthodontics. 88. 
922

923

924

925

926

927

928

929

930

931

932

933

934

935

936

937

938

939

940

941

942

943

944

945

946

947

948

949

950

951

952

953

Orban, B.J., Bhaskar, S.N., 1980. Orban's Oral histology and embryology, 9th ed. ed. Mosby, St. Louis.

Pécora, J.D., Estrela, C., Bueno, M.R., Porto, O.C., Alencar, A.H.G., Sousa-Neto, M.D., de Araújo, C.R.E., 2013. Detection of root canal isthmuses in molars by map-reading dynamic using CBCT images. Brazilian Dental Journal. 24, 569-574.

Pickrell, J.K., Reich, D., 2014. Toward a new history and geography of human genes informed by ancient DNA. Trends in Genetics.

Plavcan, J.M., Daegling, D.J., 2006. Interspecific and intraspecific relationships between tooth size and jaw size in primates. Journal of Human Evolution. 51, 171-184.

Posth, C., Nakatsuka, N., Lazaridis, I., Skoglund, P., Mallick, S., Lamnidis, T.C., Rohland, N., Nägele, K., Adamski, N., Bertolini, E., Broomandkhoshbacht, N., Cooper, A., Culleton, B.J., Ferraz, T., Ferry, M., Furtwängler, A., Haak, W., Harkins, K., Harper, T.K., Hünemeier, T., Lawson, A.M., Llamas, B., Michel, M., Nelson, E., Oppenheimer, J., Patterson, N., Schiffels, S., Sedig, J., Stewardson, K., Talamo, S., Wang, C.C., Hublin, J.J., Hubbe, M., Harvati, K., Nuevo Delaunay, A., Beier, J., Francken, M., Kaulicke, P., ReyesCenteno, H., Rademaker, K., Trask, W.R., Robinson, M., Gutierrez, S.M., Prufer, K.M., Salazar-García, D.C., Chim, E.N., Müller Plumm Gomes, L., Alves, M.L., Liryo, A., Inglez, M., Oliveira, R.E., Bernardo, D. V., Barioni, A., Wesolowski, V., Scheifler, N.A., Rivera, M.A., Plens, C.R., Messineo, P.G., Figuti, L., Corach, D., Scabuzzo, C., Eggers, S., DeBlasis, P., Reindel, M., Méndez, C., Politis, G., Tomasto-Cagigao, E., Kennett, D.J., Strauss, A., Fehren-Schmitz, L., Krause, J., Reich, D., 2018. Reconstructing the Deep Population History of Central and South America. Cell. 175, 1185-1197.e22.

Prugnolle, F., Manica, A., Balloux, F., 2005. Geography predicts neutral genetic diversity of human populations [1]. Current Biology. 15, 159.

Rainey, F., 1941. The Ipiutak Culture at Point Hope, Alaska. American Anthropologist. 43, 364-375.

Rainey, F.G., 1947. The whale hunters of Tigara. Anthropological papers of the AMNH ; v. 41, pt. 2.

Rainey, F.G., 1971. The Ipiutak Culture: Excavations at Point Hope, Alaska. An AddisonWesley Module of Anthropology. 8, 1-32.

Rakhshan, V., 2015. Congenitally missing teeth (hypodontia): A review of the literature concerning the etiology, prevalence, risk factors, patterns and treatment. Dental 
Research Journal. 12, 1-13.

955

956

957

958

959

960

961

962

963

964

965

966

967

968

969

970

971

972

973

974

975

976

977

978

979

980

981

982

983

984

985

Rathmann, H., Reyes-Centeno, H., 2020. Testing the utility of dental morphological trait combinations for inferring human neutral genetic variation. Proceedings of the National Academy of Sciences of the United States of America. 117, 10769-10777.

Rathmann, H., Reyes-Centeno, H., Ghirotto, S., Creanza, N., Hanihara, T., Harvati, K., 2017. Reconstructing human population history from dental phenotypes. Scientific Reports. 7, 1-9.

Reed, K.E., 1997. Early hominid evolution and ecological change through the African PlioPleistocene. Journal of Human Evolution. 32, 289-322.

Reich, D., 2018. Who we are and how we got here : ancient DNA and the new science of the human past. Oxfor University Press: Oxford.

Richard Scott, G., Irish, J.D., Martinón-Torres, M.M., Scott, G.R., Irish, J.D., Martinón, M., Martinón-Torres, M.M., 2020. A more comprehensive view of the Denisovan 3-rooted lower second molar from Xiahe. Proceedings of the National Academy of Sciences of the United States of America. 117, 37-38.

Rivera, F., Mirazón-Lahr, M., 2017. New evidence suggesting a dissociated etiology for cribra orbitalia and porotic hyperostosis. American Journal of Physical Anthropology. 164, 7696.

Robinson, J.T., 1954. Prehominid dentition and dental evolution. Evolution. 8, 324-334.

Robinson, J.T., 1956. The dentition of the Australopithecinae: Australopithecines and hominid phylogenesis. Transvaal Museum Memoirs. 9, 158-175.

Scott, G., 1988. Dental Anthropology. Annual Review of Anthropology. 17, 99-126.

Scott, G.R., Hemphill, B.E., 2012. Officers of the Dental Anthropology Association. 25.

Scott, G.R., Turner II, C.G., 1988. Dental Anthropology. Annual Review of Anthropology. 17, 99-126.

Scott, G.R., Turner II, C.G., Townsend, G.C., Martinón-Torres, M., 2018. The anthropology of modern human teeth: Dental morphology and its variation in recent and fossil homo sapiens: Second edition, The Anthropology of Modern Human Teeth: Dental Morphology and its Variation in Recent and Fossil Homo Sapien.

Shields, E.D., 2005. Mandibular premolar and second molar root morphological variation in modern humans: What root number can tell us about tooth morphogenesis. American Journal of Physical Anthropology. 128, 299-311. 
Skoglund, P., Posth, C., Sirak, K., Spriggs, M., Valentin, F., Bedford, S., Clark, G.R., Reepmeyer, C., Petchey, F., Fernandes, D., Fu, Q., Harney, E., Lipson, M., Mallick, S., Novak, M., Rohland, N., Stewardson, K., Abdullah, S., Cox, M.P., Friedlaender, F.R., Friedlaender, J.S., Kivisild, T., Koki, G., Kusuma, P., Merriwether, D.A., Ricaut, F.X., Wee, J.T.S., Patterson, N., Krause, J., Pinhasi, R., Reich, D., 2016. Genomic insights into the peopling of the Southwest Pacific. Nature. 538, 510-513.

Spears, I.R., Macho, G.A., 1998. Biomechanical behaviour of modern human molars: Implications for interpreting the fossil record. American Journal of Physical Anthropology. 106, 467-482.

Spencer, M.A., 2003. Tooth-Root Form and Function in Platyrrhine Seed-Eaters. American Journal of Physical Anthropology. 122, 325-335.

Sperber, G.H., 1973. Morphology of the Cheek Teeth of Early South African Hominids. Witwatersrand University: Johannesburg.

Sterne, J.A.C., White, I.R., Carlin, J.B., Spratt, M., Royston, P., Kenward, M.G., Wood, A.M., Carpenter, J.R., 2009. Multiple imputation for missing data in epidemiological and clinical research: Potential and pitfalls. BMJ (Online). 339, 157-160.

Stringer, C.B., Humphrey, L.T., Compton, T., 1997. Cladistic analysis of dental traits in recent humans using a fossil outgroup. Journal of Human Evolution. 32, 389-402.

Turner II, C.G., 1986. Dentochronological separation estimates for pacific rim populations. Science. 232, 1140-1142.

Turner II, C.G., 1987. Late Pleistocene and Holocene population history of east Asia based on dental variation. American Journal of Physical Anthropology. 73, 305-321.

Turner II, C.G., 1989. Teeth and prehistory in Asia. Scientific American.

Turner II, C.G., Nichol, C.R., Scott, G.R., 1991. Scoring procedures for key morphological traits of the permanent dentition : the Arizona State University dental anthropology system. Advances in Dental Anthropology. 13-31.

van Eijden, T.M.G.J., 1991. Three-dimensional analyses of human bite-force magnitude and moment. Archives of Oral Biology. 36, 535-539.

Vertucci, F.J., Gegauff, A., 1979. Root canal morphology of the maxillary first premolar. Journal of the American Dental Association. 99, 194-198.

White, T.D., Black, M.T., Folkens, P.A., White, T.D., Black, M.T., Folkens, P.A., 2012. Teeth. In: Human Osteology. Academic Press, pp. 101-128. 
1018

1019

1020

1021

1022

1023

1024

1025

1026

1027

1028

1029

1030

1031

1032

1033

1034

1035

1036

1037

1038

1039

1040

1041

1042

1043

1044

1045

1046

1047

1048

1049

Wood, B.A., Abbott, S.A., 1983. Analysis of the dental morphology of Plio-pleistocene hominids. I. Mandibular molars: crown area measurements and morphological traits. Journal of anatomy. 136, 197-219.

Wood, B.A., Abbott, S.A., Uytterschaut, H., 1988a. Analysis of the dental morphology of PlioPleistocene hominids. IV. Mandibular postcanine root morphology. Journal of anatomy. 156, 107-39.

Wood, B.A., Abbott, S.A., Uytterschaut, H., 1988b. Analysis of the dental morphology of PlioPleistocene hominids. IV. Mandibular postcanine root morphology. Journal of anatomy. 156, 107-39.

Wood, B.A., Constantino, P., 2007. Paranthropus boisei: Fifty years of evidence and analysis. Yearbook of Physical Anthropology. 50, 106-132.

Wright, T., 2007. The molecular control of and clinical variations in root formation. Cells Tissues Organs. 186, 86-93.

Zanolli, C., Mazurier, A., 2013. Endostructural characterization of the H.heidelbergensis dental remains from the early middle pleistocene site of Tighenif, Algeria. Comptes Rendus - Palevol. 12, 293-304.

Zeger, S.L., Liang, K.-Y., 1986. Longitudinal Data Analysis for Discrete and Continuous Outcomes. Biometrics. 42, 121.

Zeileis, A., Kleiber, C., Jackman, S., 2008. Regression models for count data in R. Journal of Statistical Software. 27, 1-25.

Zhang, Yuqing, Alyass, A., Vanniyasingam, T., Sadeghirad, B., Flórez, I.D., Pichika, S.C., Kennedy, S.A., Abdulkarimova, U., Zhang, Yuan, Iljon, T., Morgano, G.P., Colunga Lozano, L.E., Aloweni, F.A.B., Lopes, L.C., Yepes-Nuñez, J.J., Fei, Y., Wang, L., Kahale, L.A., Meyre, D., Akl, E.A., Thabane, L., Guyatt, G.H., 2017. A systematic survey of the methods literature on the reporting quality and optimal methods of handling participants with missing outcome data for continuous outcomes in randomized controlled trials. Journal of Clinical Epidemiology. 88, 67-80.

Zorbaa, E., Vannab, V., Moraitis, K., 2014. Sexual dimorphism of root length on a Greek population sample. HOMO- Journal of Comparative Human Biology. 65, 143-154.

Zuur, A.F., leno, E.N., Walker, N., Saveliev, A.A., Smith, G.M., 2009. Mixed effects models and extensions in ecology with R, Statistics for Biology and Health. Springer New York, New York, NY. 
bioRxiv preprint doi: https://doi.org/10.1101/2022.02.01.478656; this version posted February 3, 2022. The copyright holder for this preprint (which was not certified by peer review) is the author/funder, who has granted bioRxiv a license to display the preprint in perpetuity. It is made available under aCC-BY-NC-ND 4.0 International license.

\section{Supplementary Material}

1053 Table A: Collection information for individuals used in this study

\begin{tabular}{|c|c|c|c|c|c|c|c|c|}
\hline ID & Collection & Sex & $\begin{array}{c}\text { Years } \\
\text { BP* }\end{array}$ & $\mathrm{G}^{+}$ & G2 & G3 & G4 & G5 \\
\hline 99_1_102 & AMNH & $\mathrm{F}$ & $\sim 1600$ & Sino-Americas & North America & $\begin{array}{c}\text { American } \\
\text { Arctic }\end{array}$ & Alaska & Ipiutak \\
\hline 99_1_103 & AMNH & M & $\sim 1600$ & Sino-Americas & North America & $\begin{array}{c}\text { American } \\
\text { Arctic }\end{array}$ & Alaska & Ipiutak \\
\hline 99_1_105 & AMNH & M & $\sim 1600$ & Sino-Americas & North America & $\begin{array}{l}\text { American } \\
\text { Arctic }\end{array}$ & Alaska & Ipiutak \\
\hline 99_1_161 & AMNH & $\mathrm{F}$ & $\sim 1600$ & Sino-Americas & North America & $\begin{array}{c}\text { American } \\
\text { Arctic }\end{array}$ & Alaska & Ipiutak \\
\hline 99_1_163 & AMNH & $\mathrm{F}$ & $\sim 1600$ & Sino-Americas & North America & $\begin{array}{c}\text { American } \\
\text { Arctic }\end{array}$ & Alaska & Ipiutak \\
\hline 99_1_165 & AMNH & M & $\sim 1600$ & Sino-Americas & North America & $\begin{array}{l}\text { American } \\
\text { Arctic }\end{array}$ & Alaska & Ipiutak \\
\hline 99_1_166 & AMNH & M & $\sim 1600$ & Sino-Americas & North America & $\begin{array}{c}\text { American } \\
\text { Arctic }\end{array}$ & Alaska & Ipiutak \\
\hline 99_1_168 & AMNH & $\mathrm{F}$ & $\sim 1600$ & Sino-Americas & North America & $\begin{array}{c}\text { American } \\
\text { Arctic }\end{array}$ & Alaska & Ipiutak \\
\hline 99_1_181 & $\mathrm{AMNH}$ & M & $\sim 1600$ & Sino-Americas & North America & $\begin{array}{c}\text { American } \\
\text { Arctic }\end{array}$ & Alaska & Ipiutak \\
\hline 99_1_192 & AMNH & M & $\sim 1600$ & Sino-Americas & North America & $\begin{array}{c}\text { American } \\
\text { Arctic }\end{array}$ & Alaska & Ipiutak \\
\hline 99_1_194 & $\mathrm{AMNH}$ & M & $\sim 1600$ & Sino-Americas & North America & $\begin{array}{l}\text { American } \\
\text { Arctic }\end{array}$ & Alaska & Ipiutak \\
\hline 99_1_196 & AMNH & M & $\sim 1600$ & Sino-Americas & North America & $\begin{array}{c}\text { American } \\
\text { Arctic }\end{array}$ & Alaska & Ipiutak \\
\hline 99_1_197 & AMNH & $\mathrm{F}$ & $\sim 1600$ & Sino-Americas & North America & $\begin{array}{c}\text { American } \\
\text { Arctic }\end{array}$ & Alaska & Ipiutak \\
\hline 99_1_198 & $\mathrm{AMNH}$ & NA & $\sim 1600$ & Sino-Americas & North America & $\begin{array}{c}\text { American } \\
\text { Arctic }\end{array}$ & Alaska & Ipiutak \\
\hline 99_1_201 & $\mathrm{AMNH}$ & $\mathrm{F}$ & $\sim 1600$ & Sino-Americas & North America & $\begin{array}{c}\text { American } \\
\text { Arctic }\end{array}$ & Alaska & Ipiutak \\
\hline 99_1_252 & $\mathrm{AMNH}$ & M & $\sim 1600$ & Sino-Americas & North America & $\begin{array}{c}\text { American } \\
\text { Arctic }\end{array}$ & Alaska & Ipiutak \\
\hline 99_1_684 & $\mathrm{AMNH}$ & $\mathrm{F}$ & $\sim 1600$ & Sino-Americas & North America & $\begin{array}{c}\text { American } \\
\text { Arctic }\end{array}$ & Alaska & Ipiutak \\
\hline 99_1_72 & $\mathrm{AMNH}$ & M & $\sim 1600$ & Sino-Americas & North America & $\begin{array}{c}\text { American } \\
\text { Arctic }\end{array}$ & Alaska & Ipiutak \\
\hline 99_1_80 & $\mathrm{AMNH}$ & M & $\sim 1600$ & Sino-Americas & North America & $\begin{array}{c}\text { American } \\
\text { Arctic }\end{array}$ & Alaska & Ipiutak \\
\hline 99_1_90 & $\mathrm{AMNH}$ & $\mathrm{F}$ & $\sim 1600$ & Sino-Americas & North America & $\begin{array}{l}\text { American } \\
\text { Arctic }\end{array}$ & Alaska & Ipiutak \\
\hline 99_1_92 & $\mathrm{AMNH}$ & $M$ & $\sim 1600$ & Sino-Americas & North America & $\begin{array}{c}\text { American } \\
\text { Arctic }\end{array}$ & Alaska & Ipiutak \\
\hline 99_1_93 & $\mathrm{AMNH}$ & M & $\sim 1600$ & Sino-Americas & North America & $\begin{array}{c}\text { American } \\
\text { Arctic }\end{array}$ & Alaska & Ipiutak \\
\hline 99_1_94 & AMNH & M & $\sim 1600$ & Sino-Americas & North America & $\begin{array}{c}\text { American } \\
\text { Arctic }\end{array}$ & Alaska & Ipiutak \\
\hline 99_1_95 & $\mathrm{AMNH}$ & NA & $\sim 1600$ & Sino-Americas & North America & $\begin{array}{l}\text { American } \\
\text { Arctic }\end{array}$ & Alaska & Ipiutak \\
\hline 99_1_256 & AMNH & M & Unkw & Sino-Americas & North America & $\begin{array}{c}\text { American } \\
\text { Arctic }\end{array}$ & Alaska & NA \\
\hline 99_1_569 & AMNH & $\mathrm{F}$ & Unkw & Sino-Americas & North America & $\begin{array}{l}\text { American } \\
\text { Arctic }\end{array}$ & Alaska & NA \\
\hline 99_1_575 & AMNH & $\mathrm{F}$ & Unkw & Sino-Americas & North America & $\begin{array}{c}\text { American } \\
\text { Arctic }\end{array}$ & Alaska & NA \\
\hline 99_1_586 & $\mathrm{AMNH}$ & $\mathrm{F}$ & Unkw & Sino-Americas & North America & $\begin{array}{c}\text { American } \\
\text { Arctic }\end{array}$ & Alaska & NA \\
\hline 99_1_592 & AMNH & $\mathrm{F}$ & Unkw & Sino-Americas & North America & $\begin{array}{c}\text { American } \\
\text { Arctic }\end{array}$ & Alaska & NA \\
\hline 99_1_606 & $\mathrm{AMNH}$ & $\mathrm{F}$ & Unkw & Sino-Americas & North America & $\begin{array}{c}\text { American } \\
\text { Arctic }\end{array}$ & Alaska & NA \\
\hline 99_1_607 & AMNH & M & Unkw & Sino-Americas & North America & $\begin{array}{c}\text { American } \\
\text { Arctic }\end{array}$ & Alaska & NA \\
\hline 99_1_608 & AMNH & $\mathrm{F}$ & Unkw & Sino-Americas & North America & $\begin{array}{c}\text { American } \\
\text { Arctic }\end{array}$ & Alaska & NA \\
\hline
\end{tabular}


bioRxiv preprint doi: https://doi.org/10.1101/2022.02.01.478656; this version posted February 3, 2022. The copyright holder for this preprint (which was not certified by peer review) is the author/funder, who has granted bioRxiv a license to display the preprint in perpetuity. It is made available under aCC-BY-NC-ND 4.0 International license.

\begin{tabular}{|c|c|c|c|c|c|c|c|c|}
\hline 99_1_61 & AMNH & M & Unkw & Sino-Americas & North America & $\begin{array}{c}\text { American } \\
\text { Arctic }\end{array}$ & Alaska & NA \\
\hline 99_1_619 & AMNH & M & Unkw & Sino-Americas & North America & $\begin{array}{c}\text { American } \\
\text { Arctic }\end{array}$ & Alaska & NA \\
\hline 99_1_671 & AMNH & $\mathrm{F}$ & $\sim 800$ & Sino-Americas & North America & $\begin{array}{c}\text { American } \\
\text { Arctic }\end{array}$ & Alaska & Tigara \\
\hline 99_1_672 & AMNH & $\mathrm{F}$ & $\sim 800$ & Sino-Americas & North America & $\begin{array}{c}\text { American } \\
\text { Arctic }\end{array}$ & Alaska & Tigara \\
\hline 99_1_88 & AMNH & $\mathrm{F}$ & $\sim 800$ & Sino-Americas & North America & $\begin{array}{c}\text { American } \\
\text { Arctic }\end{array}$ & Alaska & Tigara \\
\hline 99_1_96A & AMNH & M & $\sim 800$ & Sino-Americas & North America & $\begin{array}{c}\text { American } \\
\text { Arctic }\end{array}$ & Alaska & Tigara \\
\hline 99_1_224 & AMNH & $M$ & $\sim 800$ & Sino-Americas & North America & $\begin{array}{c}\text { American } \\
\text { Arctic }\end{array}$ & Alaska & Tigara \\
\hline 99_1_225 & AMNH & M & $\sim 800$ & Sino-Americas & North America & $\begin{array}{c}\text { American } \\
\text { Arctic }\end{array}$ & Alaska & Tigara \\
\hline 99_1_228 & AMNH & M & $\sim 800$ & Sino-Americas & North America & $\begin{array}{c}\text { American } \\
\text { Arctic }\end{array}$ & Alaska & Tigara \\
\hline 99_1_233 & AMNH & $M$ & $\sim 800$ & Sino-Americas & North America & $\begin{array}{c}\text { American } \\
\text { Arctic }\end{array}$ & Alaska & Tigara \\
\hline 99_1_234 & AMNH & $\mathrm{F}$ & $\sim 800$ & Sino-Americas & North America & $\begin{array}{c}\text { American } \\
\text { Arctic }\end{array}$ & Alaska & Tigara \\
\hline 99_1_235 & AMNH & M & $\sim 800$ & Sino-Americas & North America & $\begin{array}{c}\text { American } \\
\text { Arctic }\end{array}$ & Alaska & Tigara \\
\hline 99_1_237 & AMNH & M & $\sim 800$ & Sino-Americas & North America & $\begin{array}{c}\text { American } \\
\text { Arctic }\end{array}$ & Alaska & Tigara \\
\hline 99_1_240 & AMNH & $\mathrm{F}$ & $\sim 800$ & Sino-Americas & North America & $\begin{array}{c}\text { American } \\
\text { Arctic }\end{array}$ & Alaska & Tigara \\
\hline 99_1_242 & AMNH & M & $\sim 800$ & Sino-Americas & North America & $\begin{array}{c}\text { American } \\
\text { Arctic }\end{array}$ & Alaska & Tigara \\
\hline 99_1_246 & AMNH & $\mathrm{F}$ & $\sim 800$ & Sino-Americas & North America & $\begin{array}{c}\text { American } \\
\text { Arctic }\end{array}$ & Alaska & Tigara \\
\hline 99_1_248 & AMNH & $\mathrm{F}$ & $\sim 800$ & Sino-Americas & North America & $\begin{array}{c}\text { American } \\
\text { Arctic }\end{array}$ & Alaska & Tigara \\
\hline 99_1_265 & AMNH & M & $\sim 800$ & Sino-Americas & North America & $\begin{array}{c}\text { American } \\
\text { Arctic }\end{array}$ & Alaska & Tigara \\
\hline 99_1_268 & AMNH & $\mathrm{F}$ & $\sim 800$ & Sino-Americas & North America & $\begin{array}{c}\text { American } \\
\text { Arctic }\end{array}$ & Alaska & Tigara \\
\hline 99_1_272 & AMNH & M & $\sim 800$ & Sino-Americas & North America & $\begin{array}{c}\text { American } \\
\text { Arctic }\end{array}$ & Alaska & Tigara \\
\hline 99_1_276 & AMNH & $\mathrm{F}$ & $\sim 800$ & Sino-Americas & North America & $\begin{array}{c}\text { American } \\
\text { Arctic }\end{array}$ & Alaska & Tigara \\
\hline 99_1_277 & AMNH & M & $\sim 800$ & Sino-Americas & North America & $\begin{array}{c}\text { American } \\
\text { Arctic }\end{array}$ & Alaska & Tigara \\
\hline 99_1_278 & AMNH & M & $\sim 800$ & Sino-Americas & North America & $\begin{array}{c}\text { American } \\
\text { Arctic }\end{array}$ & Alaska & Tigara \\
\hline 99_1_282 & AMNH & $\mathrm{F}$ & $\sim 800$ & Sino-Americas & North America & $\begin{array}{c}\text { American } \\
\text { Arctic }\end{array}$ & Alaska & Tigara \\
\hline 99_1_393 & AMNH & M & $\sim 800$ & Sino-Americas & North America & $\begin{array}{c}\text { American } \\
\text { Arctic }\end{array}$ & Alaska & Tigara \\
\hline 99_1_394 & AMNH & $F$ & $\sim 800$ & Sino-Americas & North America & $\begin{array}{c}\text { American } \\
\text { Arctic }\end{array}$ & Alaska & Tigara \\
\hline 99_1_395 & AMNH & M & $\sim 800$ & Sino-Americas & North America & $\begin{array}{c}\text { American } \\
\text { Arctic }\end{array}$ & Alaska & Tigara \\
\hline 99_1_396 & AMNH & M & $\sim 800$ & Sino-Americas & North America & $\begin{array}{c}\text { American } \\
\text { Arctic }\end{array}$ & Alaska & Tigara \\
\hline 99_1_397 & AMNH & M & $\sim 800$ & Sino-Americas & North America & $\begin{array}{c}\text { American } \\
\text { Arctic }\end{array}$ & Alaska & Tigara \\
\hline 99_1_401 & AMNH & $\mathrm{F}$ & $\sim 800$ & Sino-Americas & North America & $\begin{array}{c}\text { American } \\
\text { Arctic }\end{array}$ & Alaska & Tigara \\
\hline 99_1_406 & AMNH & NA & $\sim 800$ & Sino-Americas & North America & $\begin{array}{c}\text { American } \\
\text { Arctic }\end{array}$ & Alaska & Tigara \\
\hline 99_1_407 & AMNH & $M$ & $\sim 800$ & Sino-Americas & North America & $\begin{array}{c}\text { American } \\
\text { Arctic }\end{array}$ & Alaska & Tigara \\
\hline 99_1_408 & AMNH & $M$ & $\sim 800$ & Sino-Americas & North America & $\begin{array}{c}\text { American } \\
\text { Arctic }\end{array}$ & Alaska & Tigara \\
\hline 99_1_409 & AMNH & $\mathrm{F}$ & $\sim 800$ & Sino-Americas & North America & $\begin{array}{c}\text { American } \\
\text { Arctic }\end{array}$ & Alaska & Tigara \\
\hline 99_1_410 & AMNH & M & $\sim 800$ & Sino-Americas & North America & $\begin{array}{c}\text { American } \\
\text { Arctic }\end{array}$ & Alaska & Tigara \\
\hline 99_1_412 & AMNH & $\mathrm{F}$ & $\sim 800$ & Sino-Americas & North America & $\begin{array}{c}\text { American } \\
\text { Arctic }\end{array}$ & Alaska & Tigara \\
\hline 99_1_414 & AMNH & $\mathrm{F}$ & $\sim 800$ & Sino-Americas & North America & $\begin{array}{c}\text { American } \\
\text { Arctic }\end{array}$ & Alaska & Tigara \\
\hline 99_1_417 & $\mathrm{AMNH}$ & $\mathrm{F}$ & $\sim 800$ & Sino-Americas & North America & $\begin{array}{c}\text { American } \\
\text { Arctic }\end{array}$ & Alaska & Tigara \\
\hline
\end{tabular}


bioRxiv preprint doi: https://doi.org/10.1101/2022.02.01.478656; this version posted February 3, 2022. The copyright holder for this preprint (which was not certified by peer review) is the author/funder, who has granted bioRxiv a license to display the preprint in perpetuity. It is made available under aCC-BY-NC-ND 4.0 International license.

\begin{tabular}{|c|c|c|c|c|c|c|c|c|}
\hline 99_1_421 & AMNH & $F$ & $\sim 800$ & Sino-Americas & North America & $\begin{array}{c}\text { American } \\
\text { Arctic }\end{array}$ & Alaska & Tigara \\
\hline 99_1_422 & AMNH & $\mathrm{F}$ & $\sim 800$ & Sino-Americas & North America & $\begin{array}{c}\text { American } \\
\text { Arctic }\end{array}$ & Alaska & Tigara \\
\hline 99_1_423 & AMNH & M & $\sim 800$ & Sino-Americas & North America & $\begin{array}{c}\text { American } \\
\text { Arctic }\end{array}$ & Alaska & Tigara \\
\hline 99_1_424 & AMNH & $\mathrm{F}$ & $\sim 800$ & Sino-Americas & North America & $\begin{array}{c}\text { American } \\
\text { Arctic }\end{array}$ & Alaska & Tigara \\
\hline 99_1_425 & AMNH & $\mathrm{F}$ & $\sim 800$ & Sino-Americas & North America & $\begin{array}{c}\text { American } \\
\text { Arctic }\end{array}$ & Alaska & Tigara \\
\hline 99_1_426 & AMNH & $M$ & $\sim 800$ & Sino-Americas & North America & $\begin{array}{c}\text { American } \\
\text { Arctic }\end{array}$ & Alaska & Tigara \\
\hline 99_1_428 & AMNH & $M$ & $\sim 800$ & Sino-Americas & North America & $\begin{array}{c}\text { American } \\
\text { Arctic }\end{array}$ & Alaska & Tigara \\
\hline 99_1_429 & AMNH & $\mathrm{F}$ & $\sim 800$ & Sino-Americas & North America & $\begin{array}{c}\text { American } \\
\text { Arctic }\end{array}$ & Alaska & Tigara \\
\hline 99_1_431 & AMNH & M & $\sim 800$ & Sino-Americas & North America & $\begin{array}{c}\text { American } \\
\text { Arctic }\end{array}$ & Alaska & Tigara \\
\hline 99_1_432 & AMNH & $M$ & $\sim 800$ & Sino-Americas & North America & $\begin{array}{c}\text { American } \\
\text { Arctic }\end{array}$ & Alaska & Tigara \\
\hline 99_1_434 & AMNH & $M$ & $\sim 800$ & Sino-Americas & North America & $\begin{array}{c}\text { American } \\
\text { Arctic }\end{array}$ & Alaska & Tigara \\
\hline 99_1_438 & AMNH & $\mathrm{F}$ & $\sim 800$ & Sino-Americas & North America & $\begin{array}{c}\text { American } \\
\text { Arctic }\end{array}$ & Alaska & Tigara \\
\hline 99_1_439 & AMNH & M & $\sim 800$ & Sino-Americas & North America & $\begin{array}{c}\text { American } \\
\text { Arctic }\end{array}$ & Alaska & Tigara \\
\hline 99_1_441 & AMNH & $M$ & $\sim 800$ & Sino-Americas & North America & $\begin{array}{c}\text { American } \\
\text { Arctic }\end{array}$ & Alaska & Tigara \\
\hline 99_1_442 & AMNH & $F$ & $\sim 800$ & Sino-Americas & North America & $\begin{array}{c}\text { American } \\
\text { Arctic }\end{array}$ & Alaska & Tigara \\
\hline 99_1_444 & AMNH & $\mathrm{F}$ & $\sim 800$ & Sino-Americas & North America & $\begin{array}{c}\text { American } \\
\text { Arctic }\end{array}$ & Alaska & Tigara \\
\hline 99_1_445 & AMNH & $M$ & $\sim 800$ & Sino-Americas & North America & $\begin{array}{c}\text { American } \\
\text { Arctic }\end{array}$ & Alaska & Tigara \\
\hline 99_1_446 & AMNH & M & $\sim 800$ & Sino-Americas & North America & $\begin{array}{c}\text { American } \\
\text { Arctic }\end{array}$ & Alaska & Tigara \\
\hline 99_1_447 & AMNH & M & $\sim 800$ & Sino-Americas & North America & $\begin{array}{c}\text { American } \\
\text { Arctic }\end{array}$ & Alaska & Tigara \\
\hline 99_1_449 & AMNH & $\mathrm{F}$ & $\sim 800$ & Sino-Americas & North America & $\begin{array}{c}\text { American } \\
\text { Arctic }\end{array}$ & Alaska & Tigara \\
\hline 99_1_450 & AMNH & M & $\sim 800$ & Sino-Americas & North America & $\begin{array}{c}\text { American } \\
\text { Arctic }\end{array}$ & Alaska & Tigara \\
\hline 99_1_452 & AMNH & M & $\sim 800$ & Sino-Americas & North America & $\begin{array}{c}\text { American } \\
\text { Arctic }\end{array}$ & Alaska & Tigara \\
\hline 99_1_453 & AMNH & M & $\sim 800$ & Sino-Americas & North America & $\begin{array}{c}\text { American } \\
\text { Arctic }\end{array}$ & Alaska & Tigara \\
\hline 99_1_454 & AMNH & $\mathrm{F}$ & $\sim 800$ & Sino-Americas & North America & $\begin{array}{c}\text { American } \\
\text { Arctic }\end{array}$ & Alaska & Tigara \\
\hline 99_1_458 & AMNH & $\mathrm{F}$ & $\sim 800$ & Sino-Americas & North America & $\begin{array}{c}\text { American } \\
\text { Arctic }\end{array}$ & Alaska & Tigara \\
\hline 99_1_459 & AMNH & $F$ & $\sim 800$ & Sino-Americas & North America & $\begin{array}{c}\text { American } \\
\text { Arctic }\end{array}$ & Alaska & Tigara \\
\hline 99_1_460 & AMNH & $M$ & $\sim 800$ & Sino-Americas & North America & $\begin{array}{c}\text { American } \\
\text { Arctic }\end{array}$ & Alaska & Tigara \\
\hline 99_1_463 & AMNH & $\mathrm{F}$ & $\sim 800$ & Sino-Americas & North America & $\begin{array}{c}\text { American } \\
\text { Arctic }\end{array}$ & Alaska & Tigara \\
\hline 99_1_464 & AMNH & $\mathrm{F}$ & $\sim 800$ & Sino-Americas & North America & $\begin{array}{c}\text { American } \\
\text { Arctic }\end{array}$ & Alaska & Tigara \\
\hline 99_1_465 & AMNH & $\mathrm{F}$ & $\sim 800$ & Sino-Americas & North America & $\begin{array}{c}\text { American } \\
\text { Arctic }\end{array}$ & Alaska & Tigara \\
\hline 99_1_466 & AMNH & $\mathrm{F}$ & $\sim 800$ & Sino-Americas & North America & $\begin{array}{c}\text { American } \\
\text { Arctic }\end{array}$ & Alaska & Tigara \\
\hline 99_1_468 & AMNH & M & $\sim 800$ & Sino-Americas & North America & $\begin{array}{c}\text { American } \\
\text { Arctic }\end{array}$ & Alaska & Tigara \\
\hline 99_1_472 & AMNH & M & $\sim 800$ & Sino-Americas & North America & $\begin{array}{c}\text { American } \\
\text { Arctic }\end{array}$ & Alaska & Tigara \\
\hline 99_1_473 & AMNH & $\mathrm{F}$ & $\sim 800$ & Sino-Americas & North America & $\begin{array}{c}\text { American } \\
\text { Arctic }\end{array}$ & Alaska & Tigara \\
\hline 99_1_474 & AMNH & M & $\sim 800$ & Sino-Americas & North America & $\begin{array}{c}\text { American } \\
\text { Arctic }\end{array}$ & Alaska & Tigara \\
\hline 99_1_475 & AMNH & M & $\sim 800$ & Sino-Americas & North America & $\begin{array}{c}\text { American } \\
\text { Arctic }\end{array}$ & Alaska & Tigara \\
\hline 99_1_476 & AMNH & M & $\sim 800$ & Sino-Americas & North America & $\begin{array}{c}\text { American } \\
\text { Arctic }\end{array}$ & Alaska & Tigara \\
\hline 99_1_478 & AMNH & M & $\sim 800$ & Sino-Americas & North America & $\begin{array}{c}\text { American } \\
\text { Arctic }\end{array}$ & Alaska & Tigara \\
\hline
\end{tabular}


bioRxiv preprint doi: https://doi.org/10.1101/2022.02.01.478656; this version posted February 3, 2022. The copyright holder for this preprint (which was not certified by peer review) is the author/funder, who has granted bioRxiv a license to display the preprint in perpetuity. It is made available under aCC-BY-NC-ND 4.0 International license.

\begin{tabular}{|c|c|c|c|c|c|c|c|c|}
\hline 99_1_480 & AMNH & $F$ & $\sim 800$ & Sino-Americas & North America & $\begin{array}{c}\text { American } \\
\text { Arctic }\end{array}$ & Alaska & Tigara \\
\hline 99_1_481 & AMNH & M & $\sim 800$ & Sino-Americas & North America & $\begin{array}{c}\text { American } \\
\text { Arctic }\end{array}$ & Alaska & Tigara \\
\hline 99_1_482 & AMNH & $\mathrm{F}$ & $\sim 800$ & Sino-Americas & North America & $\begin{array}{c}\text { American } \\
\text { Arctic }\end{array}$ & Alaska & Tigara \\
\hline 99_1_485 & AMNH & $\mathrm{F}$ & $\sim 800$ & Sino-Americas & North America & $\begin{array}{c}\text { American } \\
\text { Arctic }\end{array}$ & Alaska & Tigara \\
\hline 99_1_488 & AMNH & $M$ & $\sim 800$ & Sino-Americas & North America & $\begin{array}{c}\text { American } \\
\text { Arctic }\end{array}$ & Alaska & Tigara \\
\hline 99_1_489 & AMNH & $\mathrm{F}$ & $\sim 800$ & Sino-Americas & North America & $\begin{array}{c}\text { American } \\
\text { Arctic }\end{array}$ & Alaska & Tigara \\
\hline 99_1_490 & AMNH & $M$ & $\sim 800$ & Sino-Americas & North America & $\begin{array}{c}\text { American } \\
\text { Arctic }\end{array}$ & Alaska & Tigara \\
\hline 99_1_492 & AMNH & $M$ & $\sim 800$ & Sino-Americas & North America & $\begin{array}{c}\text { American } \\
\text { Arctic }\end{array}$ & Alaska & Tigara \\
\hline 99_1_493 & AMNH & M & $\sim 800$ & Sino-Americas & North America & $\begin{array}{c}\text { American } \\
\text { Arctic }\end{array}$ & Alaska & Tigara \\
\hline 99_1_494 & AMNH & $\mathrm{F}$ & $\sim 800$ & Sino-Americas & North America & $\begin{array}{c}\text { American } \\
\text { Arctic }\end{array}$ & Alaska & Tigara \\
\hline 99_1_495 & AMNH & $M$ & $\sim 800$ & Sino-Americas & North America & $\begin{array}{c}\text { American } \\
\text { Arctic }\end{array}$ & Alaska & Tigara \\
\hline 99_1_496 & AMNH & $\mathrm{F}$ & $\sim 800$ & Sino-Americas & North America & $\begin{array}{c}\text { American } \\
\text { Arctic }\end{array}$ & Alaska & Tigara \\
\hline 99_1_497 & AMNH & M & $\sim 800$ & Sino-Americas & North America & $\begin{array}{c}\text { American } \\
\text { Arctic }\end{array}$ & Alaska & Tigara \\
\hline 99_1_498 & AMNH & $M$ & $\sim 800$ & Sino-Americas & North America & $\begin{array}{c}\text { American } \\
\text { Arctic }\end{array}$ & Alaska & Tigara \\
\hline 99_1_499 & AMNH & M & $\sim 800$ & Sino-Americas & North America & $\begin{array}{c}\text { American } \\
\text { Arctic }\end{array}$ & Alaska & Tigara \\
\hline 99_1_500 & AMNH & $\mathrm{F}$ & $\sim 800$ & Sino-Americas & North America & $\begin{array}{c}\text { American } \\
\text { Arctic }\end{array}$ & Alaska & Tigara \\
\hline 99_1_502 & AMNH & $\mathrm{F}$ & $\sim 800$ & Sino-Americas & North America & $\begin{array}{c}\text { American } \\
\text { Arctic }\end{array}$ & Alaska & Tigara \\
\hline 99_1_504 & AMNH & $M$ & $\sim 800$ & Sino-Americas & North America & $\begin{array}{c}\text { American } \\
\text { Arctic }\end{array}$ & Alaska & Tigara \\
\hline 99_1_506 & AMNH & M & $\sim 800$ & Sino-Americas & North America & $\begin{array}{c}\text { American } \\
\text { Arctic }\end{array}$ & Alaska & Tigara \\
\hline 99_1_507 & AMNH & $\mathrm{F}$ & $\sim 800$ & Sino-Americas & North America & $\begin{array}{c}\text { American } \\
\text { Arctic }\end{array}$ & Alaska & Tigara \\
\hline 99_1_508 & AMNH & M & $\sim 800$ & Sino-Americas & North America & $\begin{array}{c}\text { American } \\
\text { Arctic }\end{array}$ & Alaska & Tigara \\
\hline 99_1_509 & AMNH & M & $\sim 800$ & Sino-Americas & North America & $\begin{array}{c}\text { American } \\
\text { Arctic }\end{array}$ & Alaska & Tigara \\
\hline 99_1_510 & AMNH & $\mathrm{F}$ & $\sim 800$ & Sino-Americas & North America & $\begin{array}{c}\text { American } \\
\text { Arctic }\end{array}$ & Alaska & Tigara \\
\hline 99_1_511 & AMNH & M & $\sim 800$ & Sino-Americas & North America & $\begin{array}{c}\text { American } \\
\text { Arctic }\end{array}$ & Alaska & Tigara \\
\hline 99_1_513 & AMNH & $\mathrm{F}$ & $\sim 800$ & Sino-Americas & North America & $\begin{array}{c}\text { American } \\
\text { Arctic }\end{array}$ & Alaska & Tigara \\
\hline 99_1_514 & AMNH & $F$ & $\sim 800$ & Sino-Americas & North America & $\begin{array}{c}\text { American } \\
\text { Arctic }\end{array}$ & Alaska & Tigara \\
\hline 99_1_515 & AMNH & $F$ & $\sim 800$ & Sino-Americas & North America & $\begin{array}{c}\text { American } \\
\text { Arctic }\end{array}$ & Alaska & Tigara \\
\hline 99_1_517 & AMNH & $\mathrm{F}$ & $\sim 800$ & Sino-Americas & North America & $\begin{array}{c}\text { American } \\
\text { Arctic }\end{array}$ & Alaska & Tigara \\
\hline 99_1_520 & AMNH & M & $\sim 800$ & Sino-Americas & North America & $\begin{array}{c}\text { American } \\
\text { Arctic }\end{array}$ & Alaska & Tigara \\
\hline 99_1_521 & AMNH & M & $\sim 800$ & Sino-Americas & North America & $\begin{array}{c}\text { American } \\
\text { Arctic }\end{array}$ & Alaska & Tigara \\
\hline 99_1_522 & AMNH & $\mathrm{F}$ & $\sim 800$ & Sino-Americas & North America & $\begin{array}{c}\text { American } \\
\text { Arctic }\end{array}$ & Alaska & Tigara \\
\hline 99_1_523 & AMNH & $\mathrm{F}$ & $\sim 800$ & Sino-Americas & North America & $\begin{array}{c}\text { American } \\
\text { Arctic }\end{array}$ & Alaska & Tigara \\
\hline 99_1_524 & AMNH & $F$ & $\sim 800$ & Sino-Americas & North America & $\begin{array}{c}\text { American } \\
\text { Arctic }\end{array}$ & Alaska & Tigara \\
\hline 99_1_525 & AMNH & M & $\sim 800$ & Sino-Americas & North America & $\begin{array}{c}\text { American } \\
\text { Arctic }\end{array}$ & Alaska & Tigara \\
\hline 99_1_526 & AMNH & $\mathrm{F}$ & $\sim 800$ & Sino-Americas & North America & $\begin{array}{c}\text { American } \\
\text { Arctic }\end{array}$ & Alaska & Tigara \\
\hline 99_1_527 & AMNH & M & $\sim 800$ & Sino-Americas & North America & $\begin{array}{c}\text { American } \\
\text { Arctic }\end{array}$ & Alaska & Tigara \\
\hline 99_1_532 & AMNH & $\mathrm{F}$ & $\sim 800$ & Sino-Americas & North America & $\begin{array}{c}\text { American } \\
\text { Arctic }\end{array}$ & Alaska & Tigara \\
\hline 99_1_535 & AMNH & M & $\sim 800$ & Sino-Americas & North America & $\begin{array}{c}\text { American } \\
\text { Arctic }\end{array}$ & Alaska & Tigara \\
\hline
\end{tabular}


bioRxiv preprint doi: https://doi.org/10.1101/2022.02.01.478656; this version posted February 3, 2022. The copyright holder for this preprint (which was not certified by peer review) is the author/funder, who has granted bioRxiv a license to display the preprint in perpetuity. It is made available under aCC-BY-NC-ND 4.0 International license.

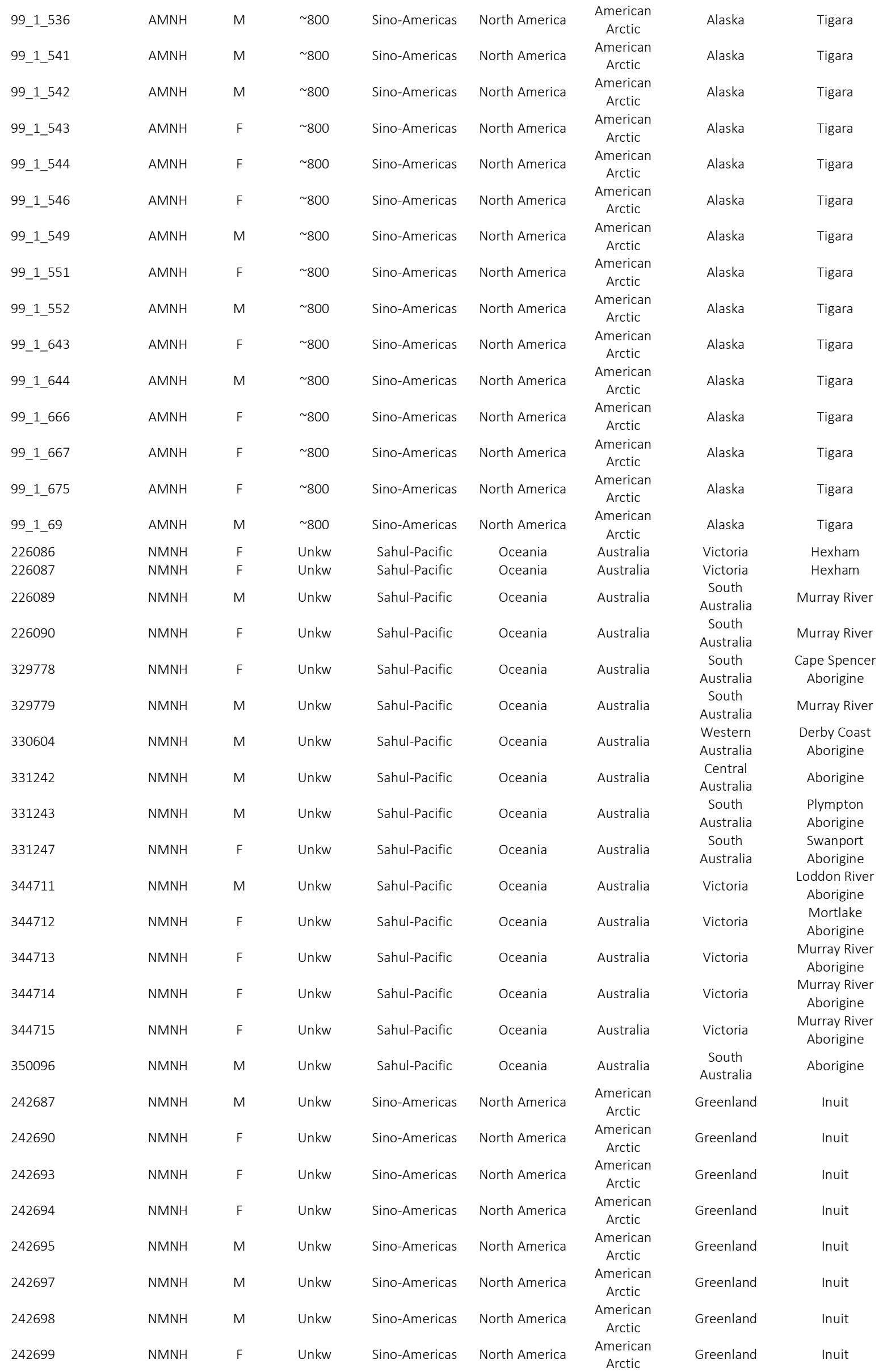


bioRxiv preprint doi: https://doi.org/10.1101/2022.02.01.478656; this version posted February 3, 2022. The copyright holder for this preprint (which was not certified by peer review) is the author/funder, who has granted bioRxiv a license to display the preprint in perpetuity. It is made available under aCC-BY-NC-ND 4.0 International license.

\begin{tabular}{|c|c|c|c|c|c|c|c|c|}
\hline 242702 & $\mathrm{NMNH}$ & $F$ & Unkw & Sino-Americas & North America & $\begin{array}{c}\text { American } \\
\text { Arctic }\end{array}$ & Greenland & Inuit \\
\hline 242704 & $\mathrm{NMNH}$ & $\mathrm{F}$ & Unkw & Sino-Americas & North America & $\begin{array}{c}\text { American } \\
\text { Arctic }\end{array}$ & Greenland & Inuit \\
\hline 242706 & $\mathrm{NMNH}$ & M & Unkw & Sino-Americas & North America & $\begin{array}{c}\text { American } \\
\text { Arctic }\end{array}$ & Greenland & Inuit \\
\hline 242707 & NMNH & $M$ & Unkw & Sino-Americas & North America & $\begin{array}{c}\text { American } \\
\text { Arctic }\end{array}$ & Greenland & Inuit \\
\hline 242708 & NMNH & $\mathrm{F}$ & Unkw & Sino-Americas & North America & $\begin{array}{c}\text { American } \\
\text { Arctic }\end{array}$ & Greenland & Inuit \\
\hline 242709 & $\mathrm{NMNH}$ & M & Unkw & Sino-Americas & North America & $\begin{array}{c}\text { American } \\
\text { Arctic }\end{array}$ & Greenland & Inuit \\
\hline 242710 & NMNH & $\mathrm{F}$ & Unkw & Sino-Americas & North America & $\begin{array}{c}\text { American } \\
\text { Arctic }\end{array}$ & Greenland & Inuit \\
\hline 242711 & NMNH & $\mathrm{F}$ & Unkw & Sino-Americas & North America & $\begin{array}{c}\text { American } \\
\text { Arctic }\end{array}$ & Greenland & Inuit \\
\hline 242712 & $\mathrm{NMNH}$ & $\mathrm{F}$ & Unkw & Sino-Americas & North America & $\begin{array}{c}\text { American } \\
\text { Arctic }\end{array}$ & Greenland & Inuit \\
\hline 242714 & $\mathrm{NMNH}$ & $\mathrm{F}$ & Unkw & Sino-Americas & North America & $\begin{array}{c}\text { American } \\
\text { Arctic }\end{array}$ & Greenland & Inuit \\
\hline 242716 & NMNH & $M$ & Unkw & Sino-Americas & North America & $\begin{array}{c}\text { American } \\
\text { Arctic }\end{array}$ & Greenland & Inuit \\
\hline 242717 & $\mathrm{NMNH}$ & $\mathrm{F}$ & Unkw & Sino-Americas & North America & $\begin{array}{c}\text { American } \\
\text { Arctic }\end{array}$ & Greenland & Inuit \\
\hline 242718 & $\mathrm{NMNH}$ & $F$ & Unkw & Sino-Americas & North America & $\begin{array}{c}\text { American } \\
\text { Arctic }\end{array}$ & Greenland & Inuit \\
\hline 242719 & NMNH & $\mathrm{F}$ & Unkw & Sino-Americas & North America & $\begin{array}{c}\text { American } \\
\text { Arctic }\end{array}$ & Greenland & Inuit \\
\hline 242720 & $\mathrm{NMNH}$ & $F$ & Unkw & Sino-Americas & North America & $\begin{array}{c}\text { American } \\
\text { Arctic }\end{array}$ & Greenland & Inuit \\
\hline 242721 & $\mathrm{NMNH}$ & M & Unkw & Sino-Americas & North America & $\begin{array}{c}\text { American } \\
\text { Arctic }\end{array}$ & Greenland & Inuit \\
\hline 242724 & $\mathrm{NMNH}$ & $\mathrm{F}$ & Unkw & Sino-Americas & North America & $\begin{array}{c}\text { American } \\
\text { Arctic }\end{array}$ & Greenland & Inuit \\
\hline 242725 & $\mathrm{NMNH}$ & $\mathrm{F}$ & Unkw & Sino-Americas & North America & $\begin{array}{c}\text { American } \\
\text { Arctic }\end{array}$ & Greenland & Inuit \\
\hline 242726 & $\mathrm{NMNH}$ & M & Unkw & Sino-Americas & North America & $\begin{array}{c}\text { American } \\
\text { Arctic }\end{array}$ & Greenland & Inuit \\
\hline 242729 & $\mathrm{NMNH}$ & M & Unkw & Sino-Americas & North America & $\begin{array}{c}\text { American } \\
\text { Arctic }\end{array}$ & Greenland & Inuit \\
\hline 242730 & $\mathrm{NMNH}$ & M & Unkw & Sino-Americas & North America & $\begin{array}{c}\text { American } \\
\text { Arctic }\end{array}$ & Greenland & Inuit \\
\hline 242731 & $\mathrm{NMNH}$ & $F$ & Unkw & Sino-Americas & North America & $\begin{array}{c}\text { American } \\
\text { Arctic }\end{array}$ & Greenland & Inuit \\
\hline 242732 & $\mathrm{NMNH}$ & M & Unkw & Sino-Americas & North America & $\begin{array}{c}\text { American } \\
\text { Arctic }\end{array}$ & Greenland & Inuit \\
\hline 242733 & $\mathrm{NMNH}$ & M & Unkw & Sino-Americas & North America & $\begin{array}{c}\text { American } \\
\text { Arctic }\end{array}$ & Greenland & Inuit \\
\hline 242734 & $\mathrm{NMNH}$ & M & Unkw & Sino-Americas & North America & $\begin{array}{c}\text { American } \\
\text { Arctic }\end{array}$ & Greenland & Inuit \\
\hline 242735 & $\mathrm{NMNH}$ & $F$ & Unkw & Sino-Americas & North America & $\begin{array}{c}\text { American } \\
\text { Arctic }\end{array}$ & Greenland & Inuit \\
\hline 242736 & $\mathrm{NMNH}$ & $F$ & Unkw & Sino-Americas & North America & $\begin{array}{c}\text { American } \\
\text { Arctic }\end{array}$ & Greenland & Inuit \\
\hline 242738 & $\mathrm{NMNH}$ & $\mathrm{F}$ & Unkw & Sino-Americas & North America & $\begin{array}{c}\text { American } \\
\text { Arctic }\end{array}$ & Greenland & Inuit \\
\hline 242741 & $\mathrm{NMNH}$ & $\mathrm{F}$ & Unkw & Sino-Americas & North America & $\begin{array}{c}\text { American } \\
\text { Arctic }\end{array}$ & Greenland & Inuit \\
\hline 242742 & $\mathrm{NMNH}$ & $\mathrm{F}$ & Unkw & Sino-Americas & North America & $\begin{array}{c}\text { American } \\
\text { Arctic }\end{array}$ & Greenland & Inuit \\
\hline 242743 & NMNH & $\mathrm{F}$ & Unkw & Sino-Americas & North America & $\begin{array}{c}\text { American } \\
\text { Arctic }\end{array}$ & Greenland & Inuit \\
\hline 242744 & $\mathrm{NMNH}$ & M & Unkw & Sino-Americas & North America & $\begin{array}{c}\text { American } \\
\text { Arctic }\end{array}$ & Greenland & Inuit \\
\hline 242745 & $\mathrm{NMNH}$ & $F$ & Unkw & Sino-Americas & North America & $\begin{array}{c}\text { American } \\
\text { Arctic }\end{array}$ & Greenland & Inuit \\
\hline 242746 & $\mathrm{NMNH}$ & $\mathrm{F}$ & Unkw & Sino-Americas & North America & $\begin{array}{c}\text { American } \\
\text { Arctic }\end{array}$ & Greenland & Inuit \\
\hline 242747 & $\mathrm{NMNH}$ & M & Unkw & Sino-Americas & North America & $\begin{array}{c}\text { American } \\
\text { Arctic }\end{array}$ & Greenland & Inuit \\
\hline 242748 & NMNH & M & Unkw & Sino-Americas & North America & $\begin{array}{c}\text { American } \\
\text { Arctic }\end{array}$ & Greenland & Inuit \\
\hline 242757 & NMNH & $\mathrm{F}$ & Unkw & Sino-Americas & North America & $\begin{array}{c}\text { American } \\
\text { Arctic }\end{array}$ & Greenland & Inuit \\
\hline 242758 & NMNH & $\mathrm{F}$ & Unkw & Sino-Americas & North America & $\begin{array}{c}\text { American } \\
\text { Arctic }\end{array}$ & Greenland & uit \\
\hline
\end{tabular}


bioRxiv preprint doi: https://doi.org/10.1101/2022.02.01.478656; this version posted February 3,2022 . The copyright holder for this preprint (which was not certified by peer review) is the author/funder, who has granted bioRxiv a license to display the preprint in perpetuity. It is made available under aCC-BY-NC-ND 4.0 International license.

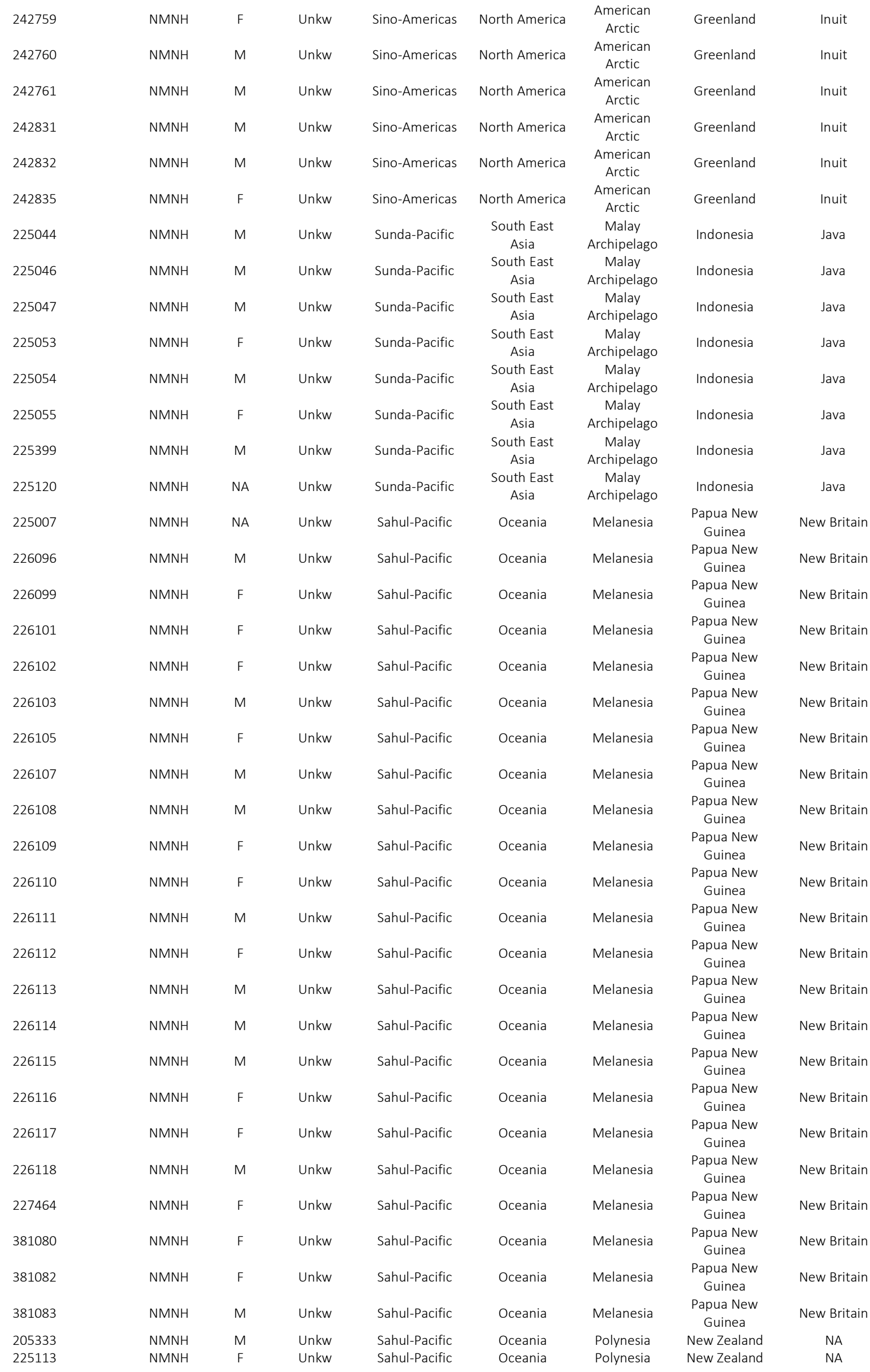


bioRxiv preprint doi: https://doi.org/10.1101/2022.02.01.478656; this version posted February 3, 2022. The copyright holder for this

preprint (which was not certified by peer review) is the author/funder, who has granted bioRxiv a license to display the preprint in perpetuity. It is made available under aCC-BY-NC-ND 4.0 International license.

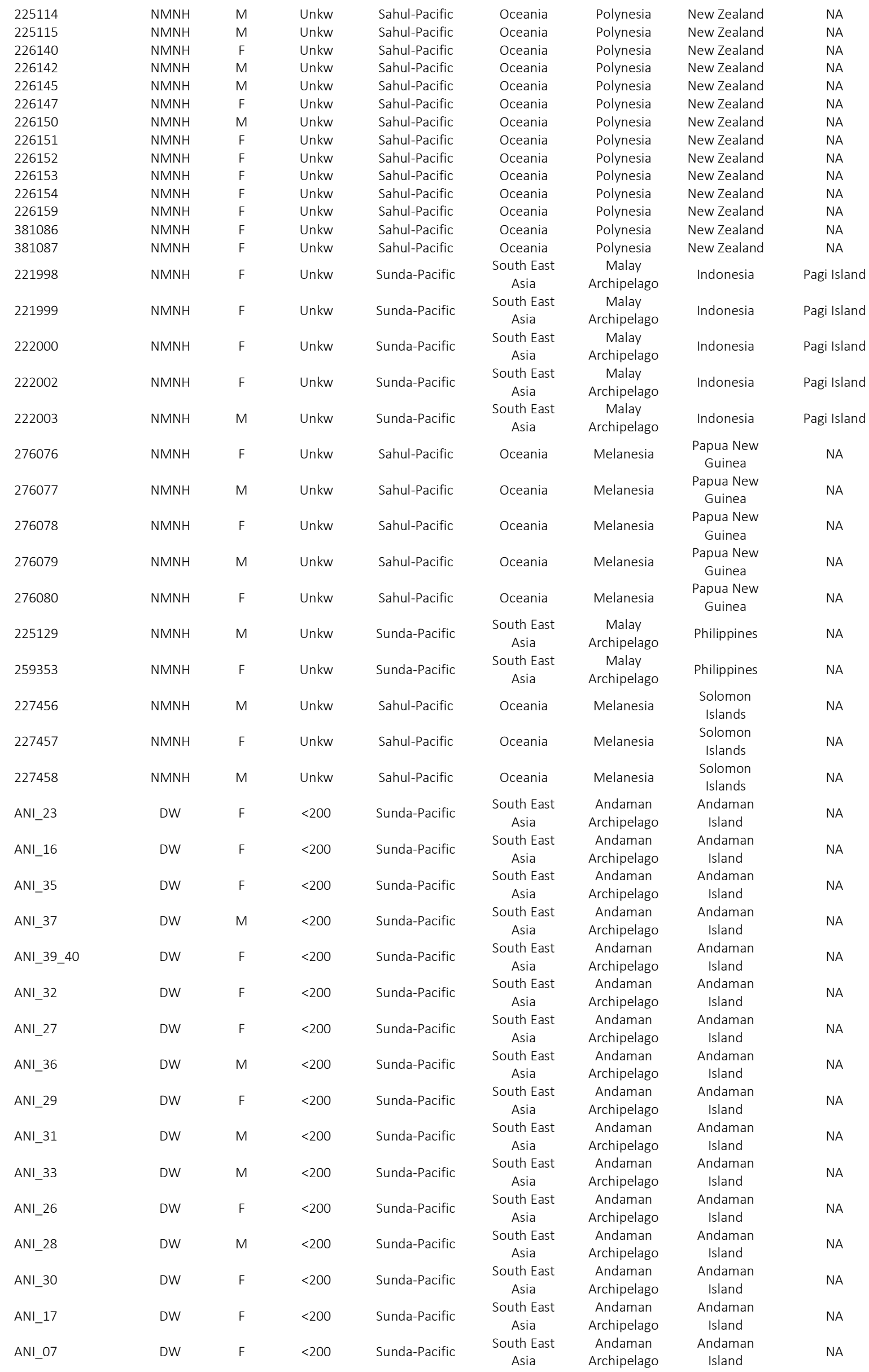


bioRxiv preprint doi: https://doi.org/10.1101/2022.02.01.478656; this version posted February 3, 2022. The copyright holder for this preprint (which was not certified by peer review) is the author/funder, who has granted bioRxiv a license to display the preprint in perpetuity. It is made available under aCC-BY-NC-ND 4.0 International license.

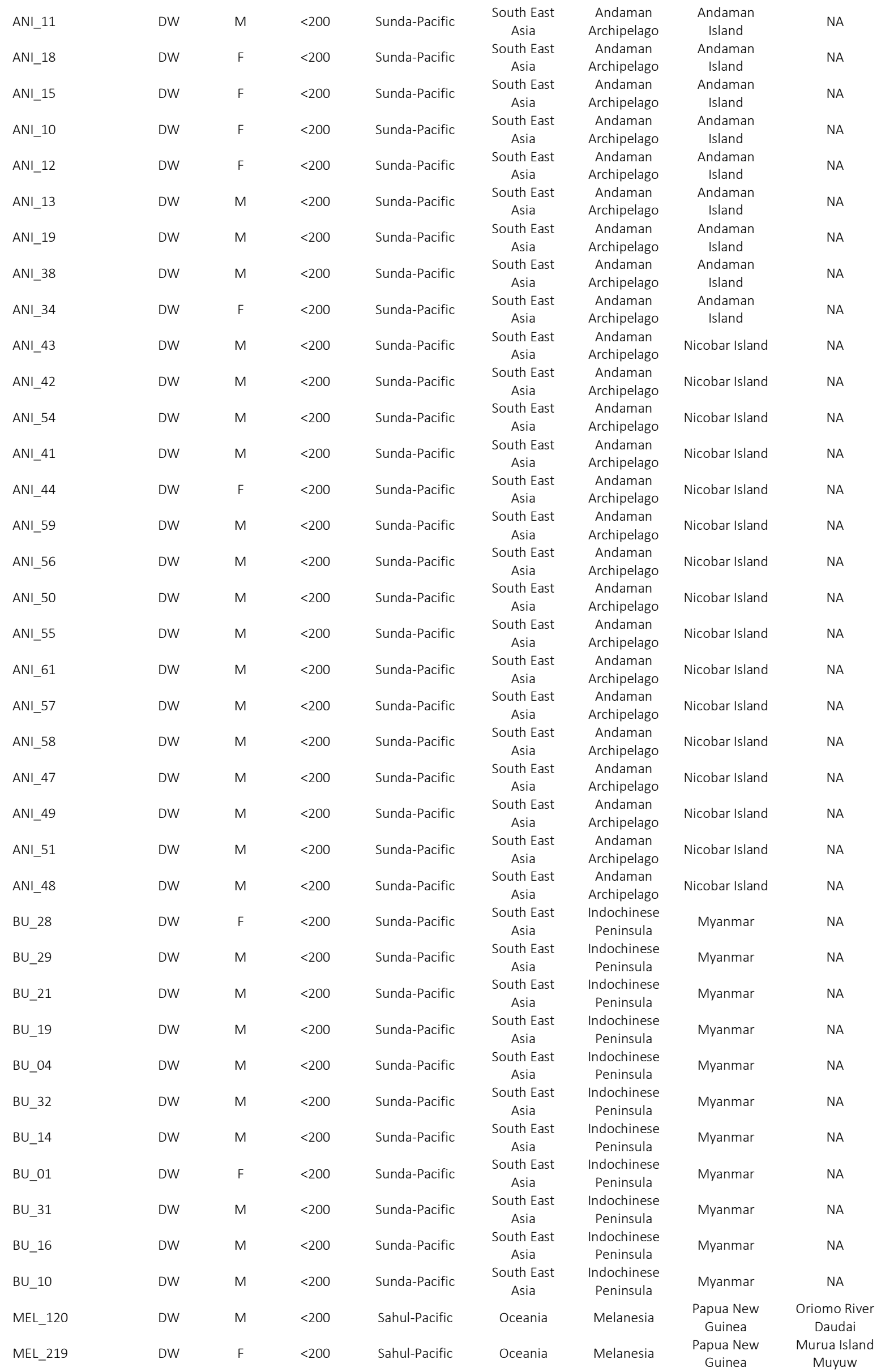


bioRxiv preprint doi: https://doi.org/10.1101/2022.02.01.478656; this version posted February 3, 2022. The copyright holder for this preprint (which was not certified by peer review) is the author/funder, who has granted bioRxiv a license to display the preprint in perpetuity. It is made available under aCC-BY-NC-ND 4.0 International license.

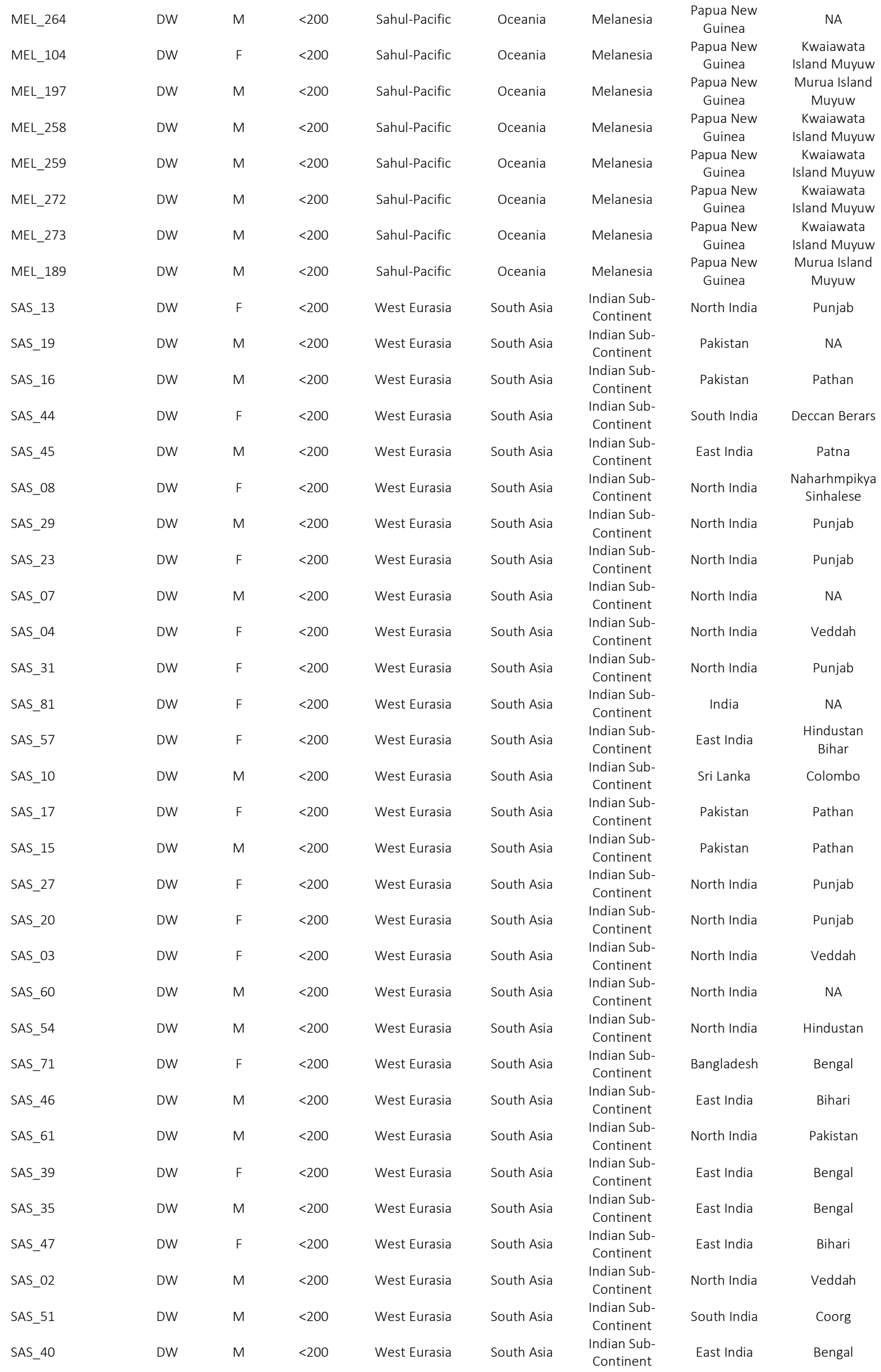


bioRxiv preprint doi: https://doi.org/10.1101/2022.02.01.478656; this version posted February 3, 2022. The copyright holder for this preprint (which was not certified by peer review) is the author/funder, who has granted bioRxiv a license to display the preprint in perpetuity. It is made available under aCC-BY-NC-ND 4.0 International license.

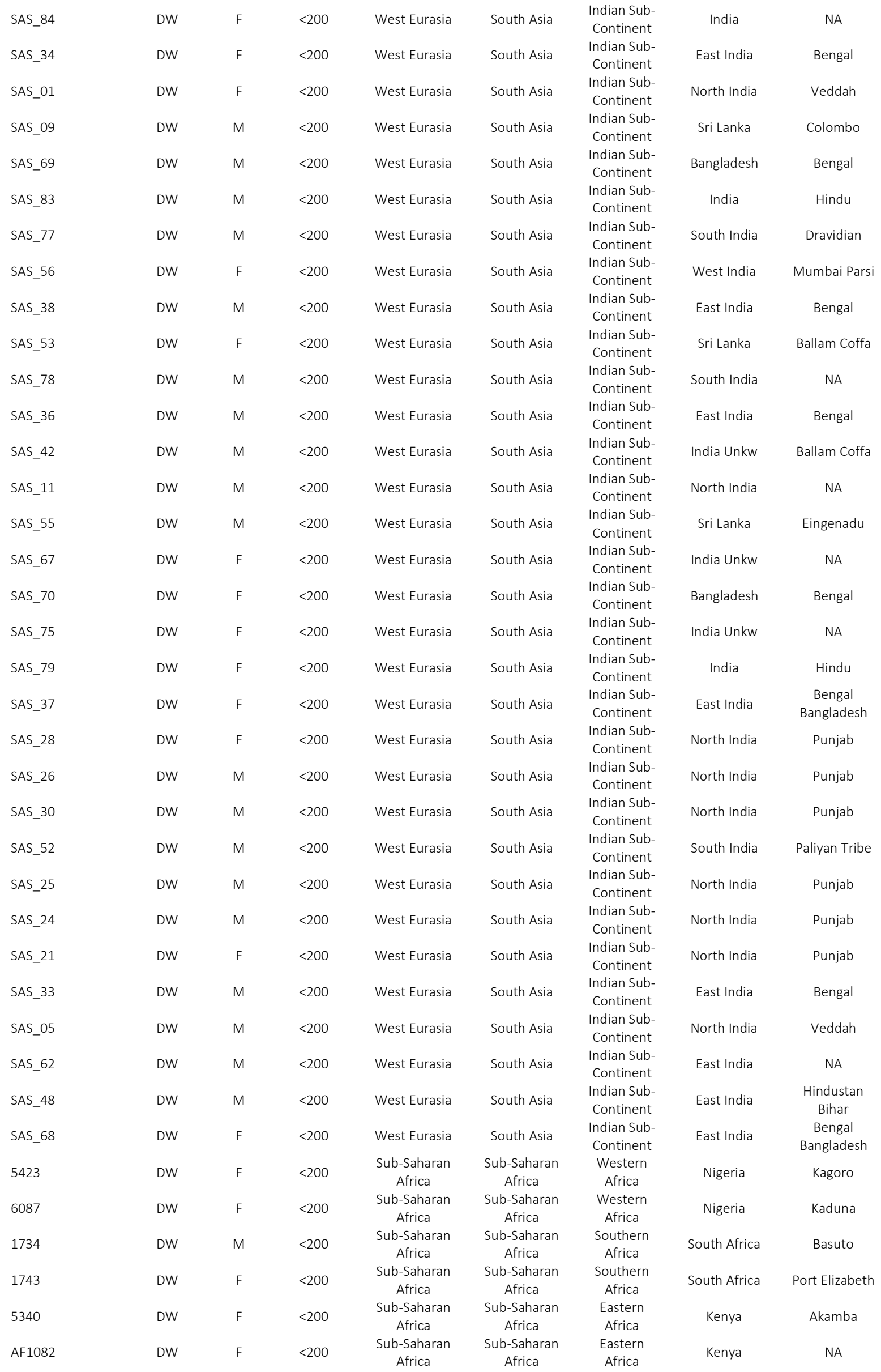


bioRxiv preprint doi: https://doi.org/10.1101/2022.02.01.478656; this version posted February 3, 2022. The copyright holder for this

preprint (which was not certified by peer review) is the author/funder, who has granted bioRxiv a license to display the preprint in perpetuity. It is made available under aCC-BY-NC-ND 4.0 International license.

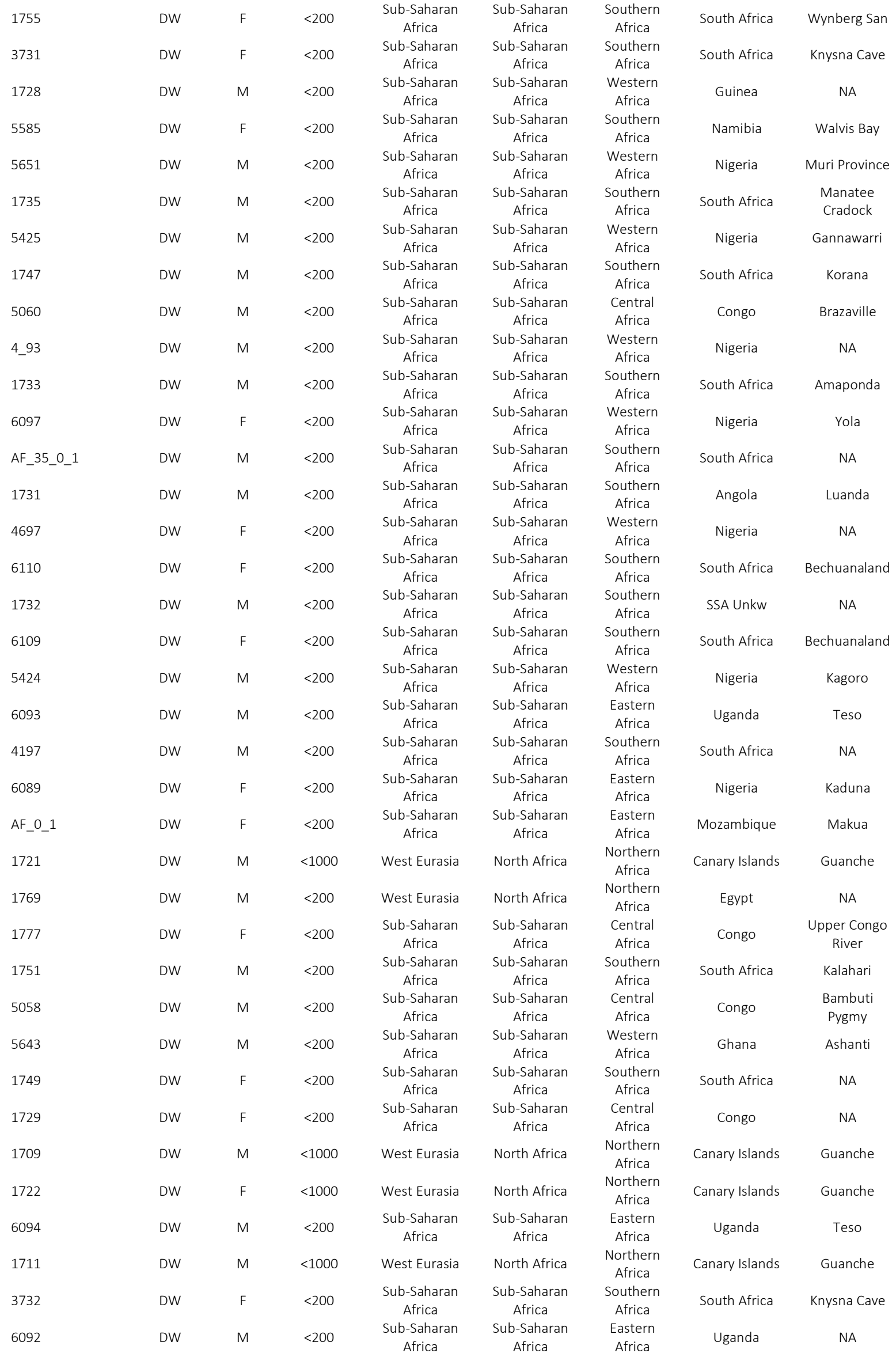


bioRxiv preprint doi: https://doi.org/10.1101/2022.02.01.478656; this version posted February 3, 2022. The copyright holder for this

preprint (which was not certified by peer review) is the author/funder, who has granted bioRxiv a license to display the preprint in perpetuity. It is made available under aCC-BY-NC-ND 4.0 International license.

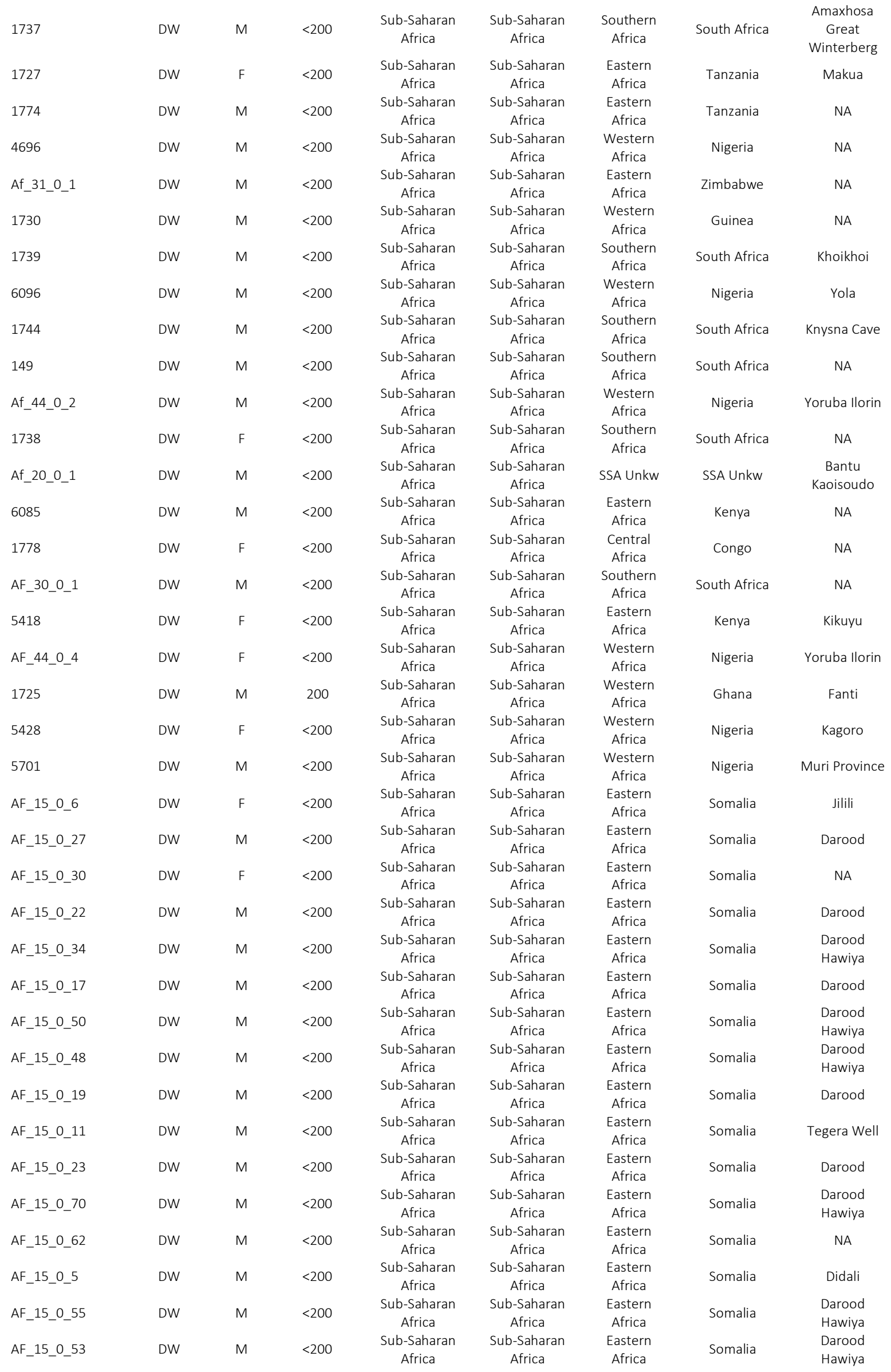


bioRxiv preprint doi: https://doi.org/10.1101/2022.02.01.478656; this version posted February 3, 2022. The copyright holder for this

preprint (which was not certified by peer review) is the author/funder, who has granted bioRxiv a license to display the preprint in perpetuity. It is made available under aCC-BY-NC-ND 4.0 International license.

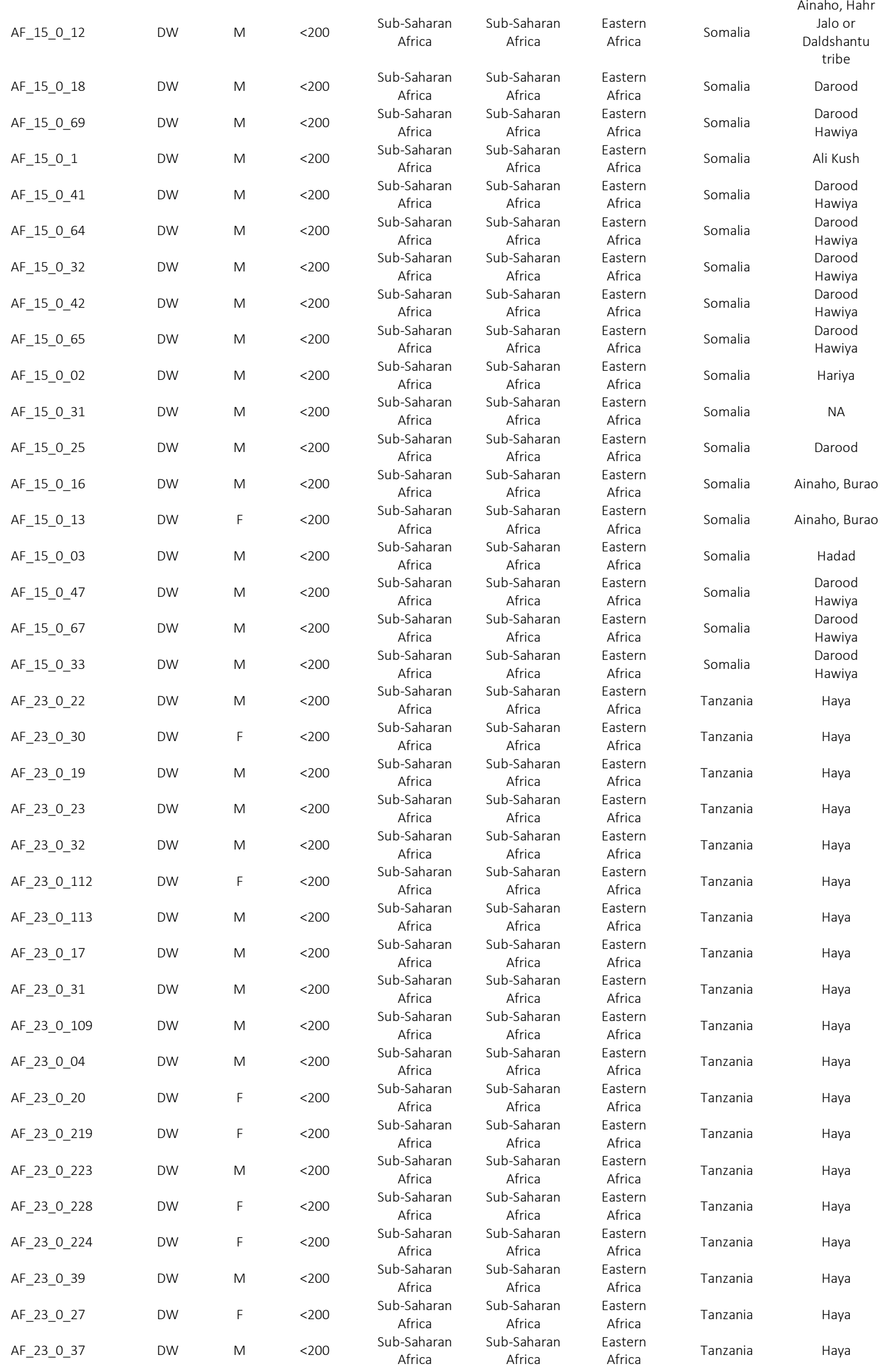


bioRxiv preprint doi: https://doi.org/10.1101/2022.02.01.478656; this version posted February 3, 2022. The copyright holder for this preprint (which was not certified by peer review) is the author/funder, who has granted bioRxiv a license to display the preprint in perpetuity. It is made available under aCC-BY-NC-ND 4.0 International license.

\begin{tabular}{|c|c|c|c|c|c|c|c|c|}
\hline AF_23_0_111 & DW & M & $<200$ & $\begin{array}{c}\text { Sub-Saharan } \\
\text { Africa }\end{array}$ & $\begin{array}{c}\text { Sub-Saharan } \\
\text { Africa }\end{array}$ & $\begin{array}{l}\text { Eastern } \\
\text { Africa }\end{array}$ & Tanzania & Haya \\
\hline AF_23_0_21_ & DW & $\mathrm{F}$ & $<200$ & $\begin{array}{c}\text { Sub-Saharan } \\
\text { Africa }\end{array}$ & $\begin{array}{c}\text { Sub-Saharan } \\
\text { Africa }\end{array}$ & $\begin{array}{l}\text { Eastern } \\
\text { Africa }\end{array}$ & Tanzania & Haya \\
\hline AF_23_0_209 & DW & $\mathrm{F}$ & $<200$ & $\begin{array}{c}\text { Sub-Saharan } \\
\text { Africa }\end{array}$ & $\begin{array}{c}\text { Sub-Saharan } \\
\text { Africa }\end{array}$ & $\begin{array}{c}\text { Eastern } \\
\text { Africa }\end{array}$ & Tanzania & Haya \\
\hline AF_23_0_35 & DW & M & $<200$ & $\begin{array}{c}\text { Sub-Saharan } \\
\text { Africa }\end{array}$ & $\begin{array}{c}\text { Sub-Saharan } \\
\text { Africa }\end{array}$ & $\begin{array}{l}\text { Eastern } \\
\text { Africa }\end{array}$ & Tanzania & Haya \\
\hline AF_23_0_118 & DW & M & $<200$ & $\begin{array}{c}\text { Sub-Saharan } \\
\text { Africa }\end{array}$ & $\begin{array}{l}\text { Sub-Saharan } \\
\text { Africa }\end{array}$ & $\begin{array}{l}\text { Eastern } \\
\text { Africa }\end{array}$ & Tanzania & Haya \\
\hline AF_23_0_115 & DW & M & $<200$ & $\begin{array}{c}\text { Sub-Saharan } \\
\text { Africa }\end{array}$ & $\begin{array}{c}\text { Sub-Saharan } \\
\text { Africa }\end{array}$ & $\begin{array}{l}\text { Eastern } \\
\text { Africa }\end{array}$ & Tanzania & Haya \\
\hline AF_23_0_225 & DW & $\mathrm{F}$ & $<200$ & $\begin{array}{c}\text { Sub-Saharan } \\
\text { Africa }\end{array}$ & $\begin{array}{c}\text { Sub-Saharan } \\
\text { Africa }\end{array}$ & $\begin{array}{l}\text { Eastern } \\
\text { Africa }\end{array}$ & Tanzania & Haya \\
\hline AF_23_0_119 & DW & M & $<200$ & $\begin{array}{c}\text { Sub-Saharan } \\
\text { Africa }\end{array}$ & $\begin{array}{c}\text { Sub-Saharan } \\
\text { Africa }\end{array}$ & $\begin{array}{l}\text { Eastern } \\
\text { Africa }\end{array}$ & Tanzania & Haya \\
\hline AF_23_0_110 & DW & M & $<200$ & $\begin{array}{c}\text { Sub-Saharan } \\
\text { Africa }\end{array}$ & $\begin{array}{c}\text { Sub-Saharan } \\
\text { Africa }\end{array}$ & $\begin{array}{l}\text { Eastern } \\
\text { Africa }\end{array}$ & Tanzania & Haya \\
\hline AF_23_0_44 & DW & $\mathrm{F}$ & $<200$ & $\begin{array}{c}\text { Sub-Saharan } \\
\text { Africa }\end{array}$ & $\begin{array}{c}\text { Sub-Saharan } \\
\text { Africa }\end{array}$ & $\begin{array}{l}\text { Eastern } \\
\text { Africa }\end{array}$ & Tanzania & Haya \\
\hline AF_23_0_38 & DW & M & $<200$ & $\begin{array}{c}\text { Sub-Saharan } \\
\text { Africa }\end{array}$ & $\begin{array}{c}\text { Sub-Saharan } \\
\text { Africa }\end{array}$ & $\begin{array}{l}\text { Eastern } \\
\text { Africa }\end{array}$ & Tanzania & Haya \\
\hline AF_23_0_213 & DW & M & $<200$ & $\begin{array}{c}\text { Sub-Saharan } \\
\text { Africa }\end{array}$ & $\begin{array}{c}\text { Sub-Saharan } \\
\text { Africa }\end{array}$ & $\begin{array}{l}\text { Eastern } \\
\text { Africa }\end{array}$ & Tanzania & Haya \\
\hline AF_23_0_36 & DW & M & $<200$ & $\begin{array}{c}\text { Sub-Saharan } \\
\text { Africa }\end{array}$ & $\begin{array}{c}\text { Sub-Saharan } \\
\text { Africa }\end{array}$ & $\begin{array}{l}\text { Eastern } \\
\text { Africa }\end{array}$ & Tanzania & Haya \\
\hline AF_23_0_218 & DW & M & $<200$ & $\begin{array}{c}\text { Sub-Saharan } \\
\text { Africa }\end{array}$ & $\begin{array}{c}\text { Sub-Saharan } \\
\text { Africa }\end{array}$ & $\begin{array}{l}\text { Eastern } \\
\text { Africa }\end{array}$ & Tanzania & Haya \\
\hline AF_23_0_25 & DW & $\mathrm{F}$ & $<200$ & $\begin{array}{c}\text { Sub-Saharan } \\
\text { Africa }\end{array}$ & $\begin{array}{c}\text { Sub-Saharan } \\
\text { Africa }\end{array}$ & $\begin{array}{l}\text { Eastern } \\
\text { Africa }\end{array}$ & Tanzania & Haya \\
\hline AF_23_0_42 & DW & $\mathrm{F}$ & $<200$ & $\begin{array}{c}\text { Sub-Saharan } \\
\text { Africa }\end{array}$ & $\begin{array}{c}\text { Sub-Saharan } \\
\text { Africa }\end{array}$ & $\begin{array}{l}\text { Eastern } \\
\text { Africa }\end{array}$ & Tanzania & Haya \\
\hline AF_23_0_114 & DW & M & $<200$ & $\begin{array}{c}\text { Sub-Saharan } \\
\text { Africa }\end{array}$ & $\begin{array}{c}\text { Sub-Saharan } \\
\text { Africa }\end{array}$ & $\begin{array}{l}\text { Eastern } \\
\text { Africa }\end{array}$ & Tanzania & Haya \\
\hline AF_23_0_200 & DW & M & $<200$ & $\begin{array}{c}\text { Sub-Saharan } \\
\text { Africa }\end{array}$ & $\begin{array}{c}\text { Sub-Saharan } \\
\text { Africa }\end{array}$ & $\begin{array}{l}\text { Eastern } \\
\text { Africa }\end{array}$ & Tanzania & Haya \\
\hline AF_23_0_18 & DW & M & $<200$ & $\begin{array}{c}\text { Sub-Saharan } \\
\text { Africa }\end{array}$ & $\begin{array}{c}\text { Sub-Saharan } \\
\text { Africa }\end{array}$ & $\begin{array}{l}\text { Eastern } \\
\text { Africa }\end{array}$ & Tanzania & Haya \\
\hline AF_23_0_202 & DW & M & $<200$ & $\begin{array}{c}\text { Sub-Saharan } \\
\text { Africa }\end{array}$ & $\begin{array}{c}\text { Sub-Saharan } \\
\text { Africa }\end{array}$ & $\begin{array}{l}\text { Eastern } \\
\text { Africa }\end{array}$ & Tanzania & Haya \\
\hline AF_23_0_116 & DW & M & $<200$ & $\begin{array}{c}\text { Sub-Saharan } \\
\text { Africa }\end{array}$ & $\begin{array}{c}\text { Sub-Saharan } \\
\text { Africa }\end{array}$ & $\begin{array}{c}\text { Eastern } \\
\text { Africa }\end{array}$ & Tanzania & Haya \\
\hline AF_23_0_227 & DW & $\mathrm{F}$ & $<200$ & $\begin{array}{c}\text { Sub-Saharan } \\
\text { Africa }\end{array}$ & $\begin{array}{c}\text { Sub-Saharan } \\
\text { Africa }\end{array}$ & $\begin{array}{l}\text { Eastern } \\
\text { Africa }\end{array}$ & Tanzania & Haya \\
\hline AF_23_0_226 & DW & M & $<200$ & $\begin{array}{c}\text { Sub-Saharan } \\
\text { Africa }\end{array}$ & $\begin{array}{c}\text { Sub-Saharan } \\
\text { Africa }\end{array}$ & $\begin{array}{c}\text { Eastern } \\
\text { Africa }\end{array}$ & Tanzania & Haya \\
\hline AF_23_0_34 & DW & $\mathrm{F}$ & $<200$ & $\begin{array}{c}\text { Sub-Saharan } \\
\text { Africa }\end{array}$ & $\begin{array}{c}\text { Sub-Saharan } \\
\text { Africa }\end{array}$ & $\begin{array}{c}\text { Eastern } \\
\text { Africa }\end{array}$ & Tanzania & Haya \\
\hline AF_23_0_8 & DW & $\mathrm{F}$ & $<200$ & $\begin{array}{c}\text { Sub-Saharan } \\
\text { Africa }\end{array}$ & $\begin{array}{c}\text { Sub-Saharan } \\
\text { Africa }\end{array}$ & $\begin{array}{l}\text { Eastern } \\
\text { Africa }\end{array}$ & Tanzania & Haya \\
\hline AF_23_0_16 & DW & M & $<200$ & $\begin{array}{c}\text { Sub-Saharan } \\
\text { Africa }\end{array}$ & $\begin{array}{c}\text { Sub-Saharan } \\
\text { Africa }\end{array}$ & $\begin{array}{c}\text { Eastern } \\
\text { Africa }\end{array}$ & Tanzania & Haya \\
\hline AF_23_0_2 & DW & M & $<200$ & $\begin{array}{c}\text { Sub-Saharan } \\
\text { Africa }\end{array}$ & $\begin{array}{c}\text { Sub-Saharan } \\
\text { Africa }\end{array}$ & $\begin{array}{c}\text { Eastern } \\
\text { Africa }\end{array}$ & Tanzania & Haya \\
\hline 1067 & DW & $M$ & $<200$ & West Eurasia & Europe & $\begin{array}{l}\text { Western } \\
\text { Europe }\end{array}$ & France & NA \\
\hline 1065 & DW & $M$ & $<200$ & West Eurasia & Europe & $\begin{array}{l}\text { Central } \\
\text { Europe }\end{array}$ & Switzerland & St Bernard \\
\hline Eu_25_00_2 & DW & $\mathrm{F}$ & $<200$ & West Eurasia & Europe & $\begin{array}{l}\text { Central } \\
\text { Europe }\end{array}$ & Switzerland & $\begin{array}{l}\text { Graubunden } \\
\text { Saint Moritz }\end{array}$ \\
\hline Eu_25_00_1 & DW & M & $<200$ & West Eurasia & Europe & $\begin{array}{l}\text { Central } \\
\text { Europe }\end{array}$ & Switzerland & $\begin{array}{l}\text { Graubunden } \\
\text { Saint Moritz }\end{array}$ \\
\hline 1036 & DW & M & $<200$ & West Eurasia & Europe & $\begin{array}{l}\text { Western } \\
\text { Europe }\end{array}$ & France & NA \\
\hline 1181 & DW & M & $<200$ & West Eurasia & Europe & $\begin{array}{l}\text { Central } \\
\text { Europe }\end{array}$ & Austrian & NA \\
\hline 1178 & DW & M & $<200$ & West Eurasia & Europe & $\begin{array}{l}\text { Northern } \\
\text { Europe }\end{array}$ & Sweden & NA \\
\hline 2235 & DW & $M$ & $<200$ & West Eurasia & Europe & $\begin{array}{l}\text { Western } \\
\text { Europe }\end{array}$ & France & Paris \\
\hline 3000 & DW & M & $<200$ & West Eurasia & Europe & $\begin{array}{l}\text { Central } \\
\text { Europe }\end{array}$ & Hungary & NA \\
\hline 1143 & DW & M & $<200$ & West Eurasia & Europe & $\begin{array}{l}\text { Central } \\
\text { Europe }\end{array}$ & Austrian & Vienna \\
\hline Eu_26_00_2 & DW & M & $<200$ & West Eurasia & Europe & $\begin{array}{l}\text { Central } \\
\text { Europe }\end{array}$ & Germany & Halle \\
\hline
\end{tabular}


bioRxiv preprint doi: https://doi.org/10.1101/2022.02.01.478656; this version posted February 3, 2022. The copyright holder for this

preprint (which was not certified by peer review) is the author/funder, who has granted bioRxiv a license to display the preprint in perpetuity. It is made available under aCC-BY-NC-ND 4.0 International license.

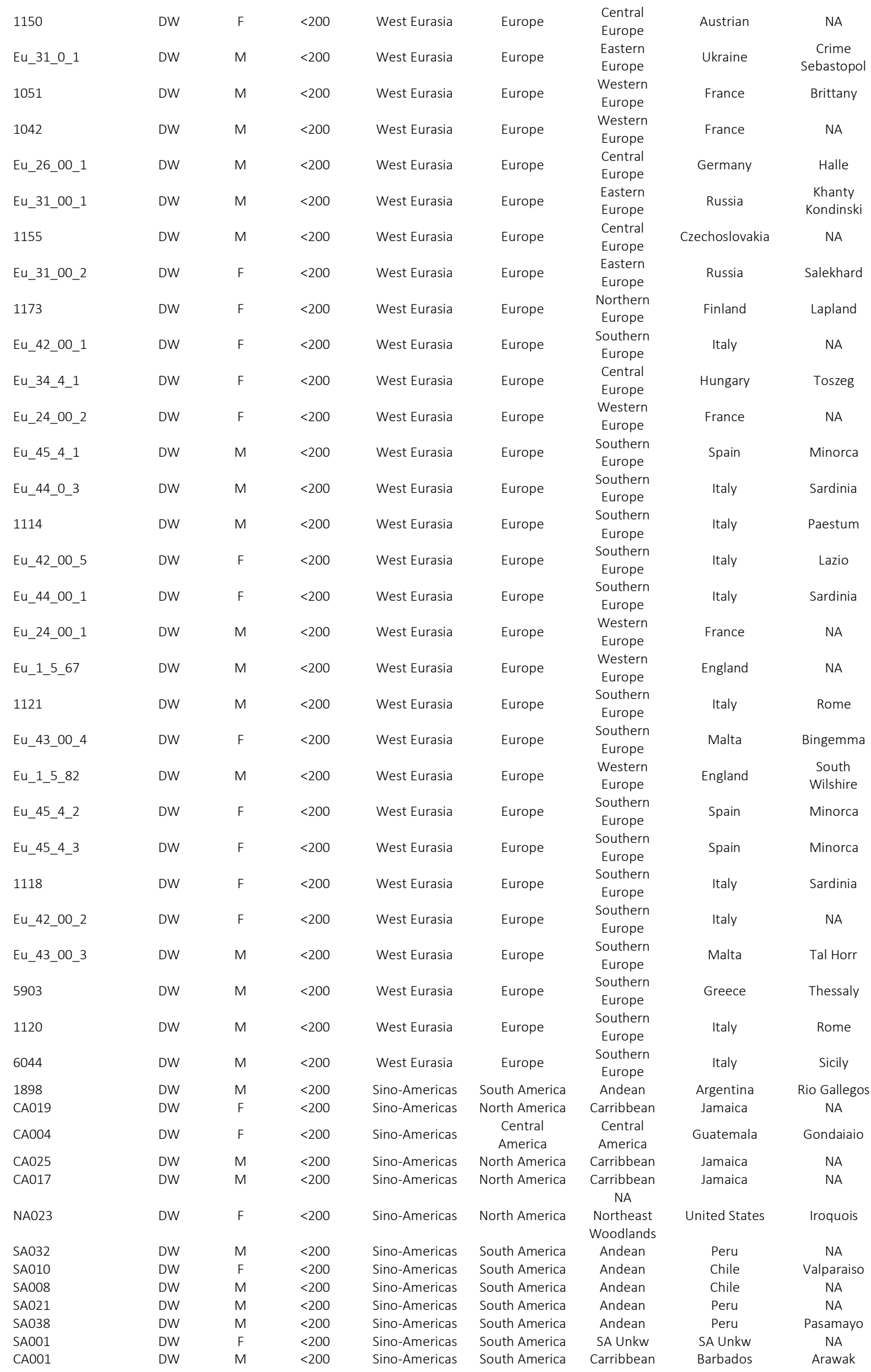


bioRxiv preprint doi: https://doi.org/10.1101/2022.02.01.478656; this version posted February 3, 2022. The copyright holder for this

preprint (which was not certified by peer review) is the author/funder, who has granted bioRxiv a license to display the preprint in perpetuity. It is made available under aCC-BY-NC-ND 4.0 International license.

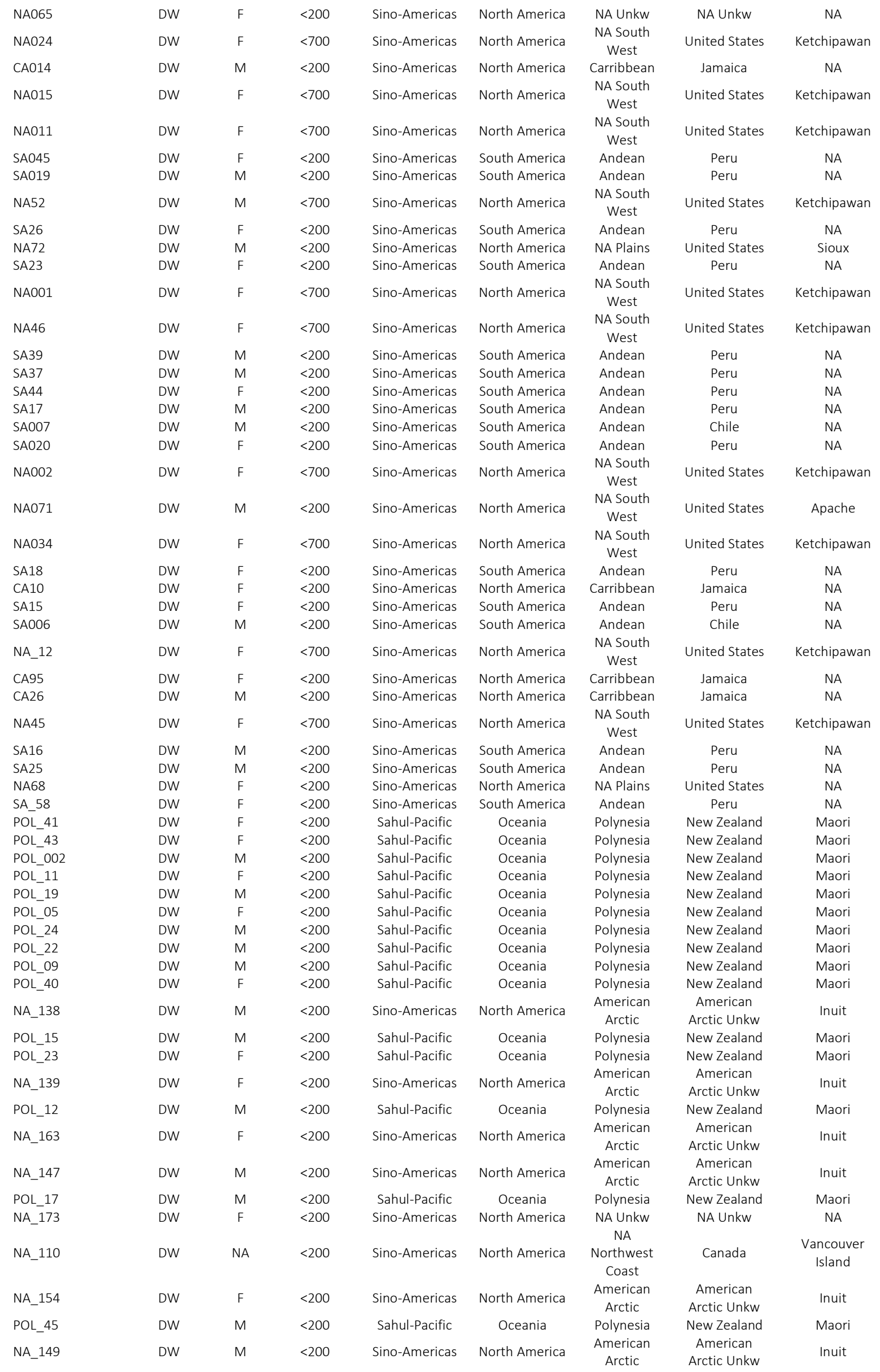


bioRxiv preprint doi: https://doi.org/10.1101/2022.02.01.478656; this version posted February 3, 2022. The copyright holder for this preprint (which was not certified by peer review) is the author/funder, who has granted bioRxiv a license to display the preprint in perpetuity. It is made available under aCC-BY-NC-ND 4.0 International license.

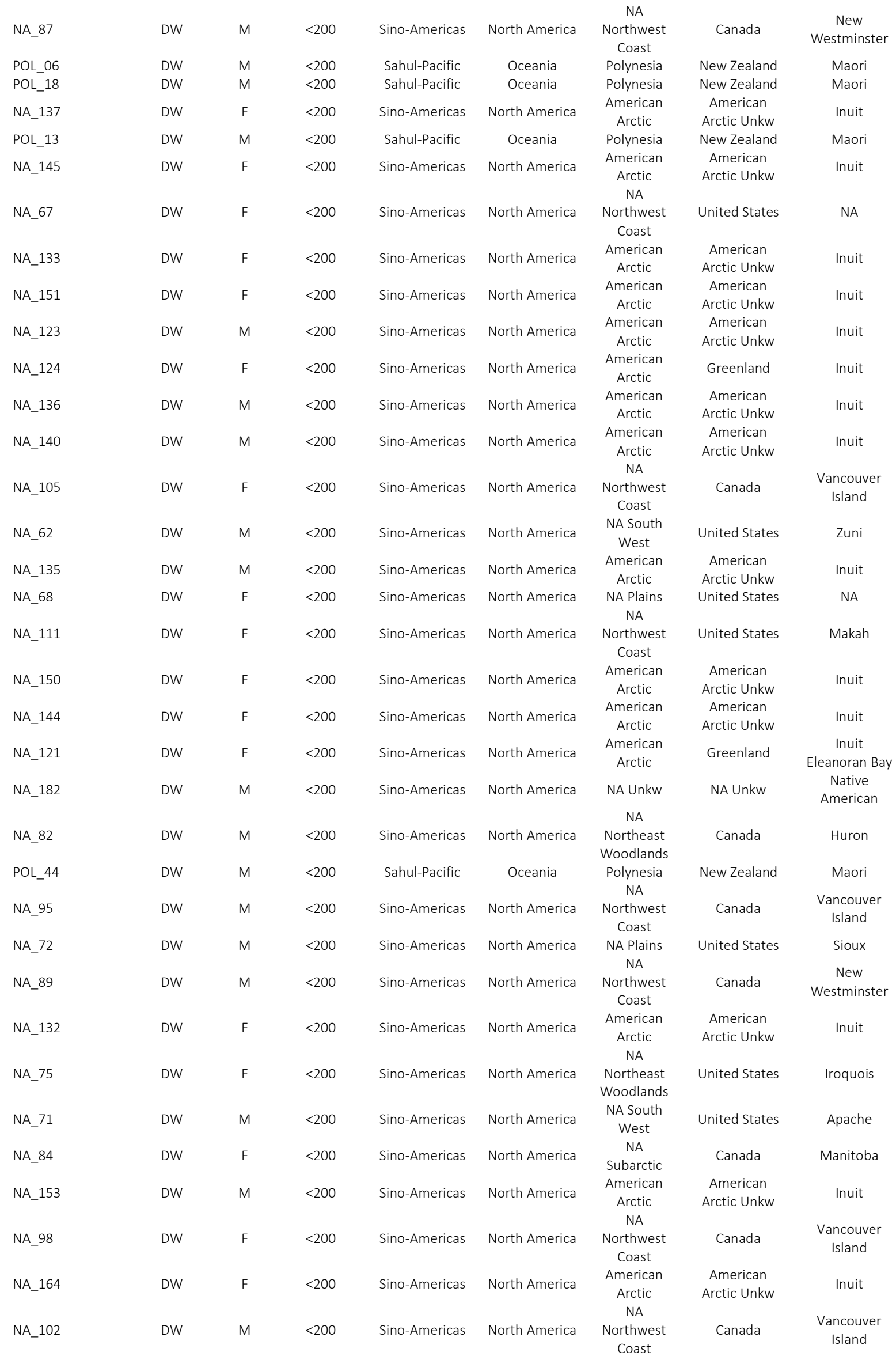


bioRxiv preprint doi: https://doi.org/10.1101/2022.02.01.478656; this version posted February 3, 2022. The copyright holder for this

preprint (which was not certified by peer review) is the author/funder, who has granted bioRxiv a license to display the preprint in perpetuity. It is made available under aCC-BY-NC-ND 4.0 International license.

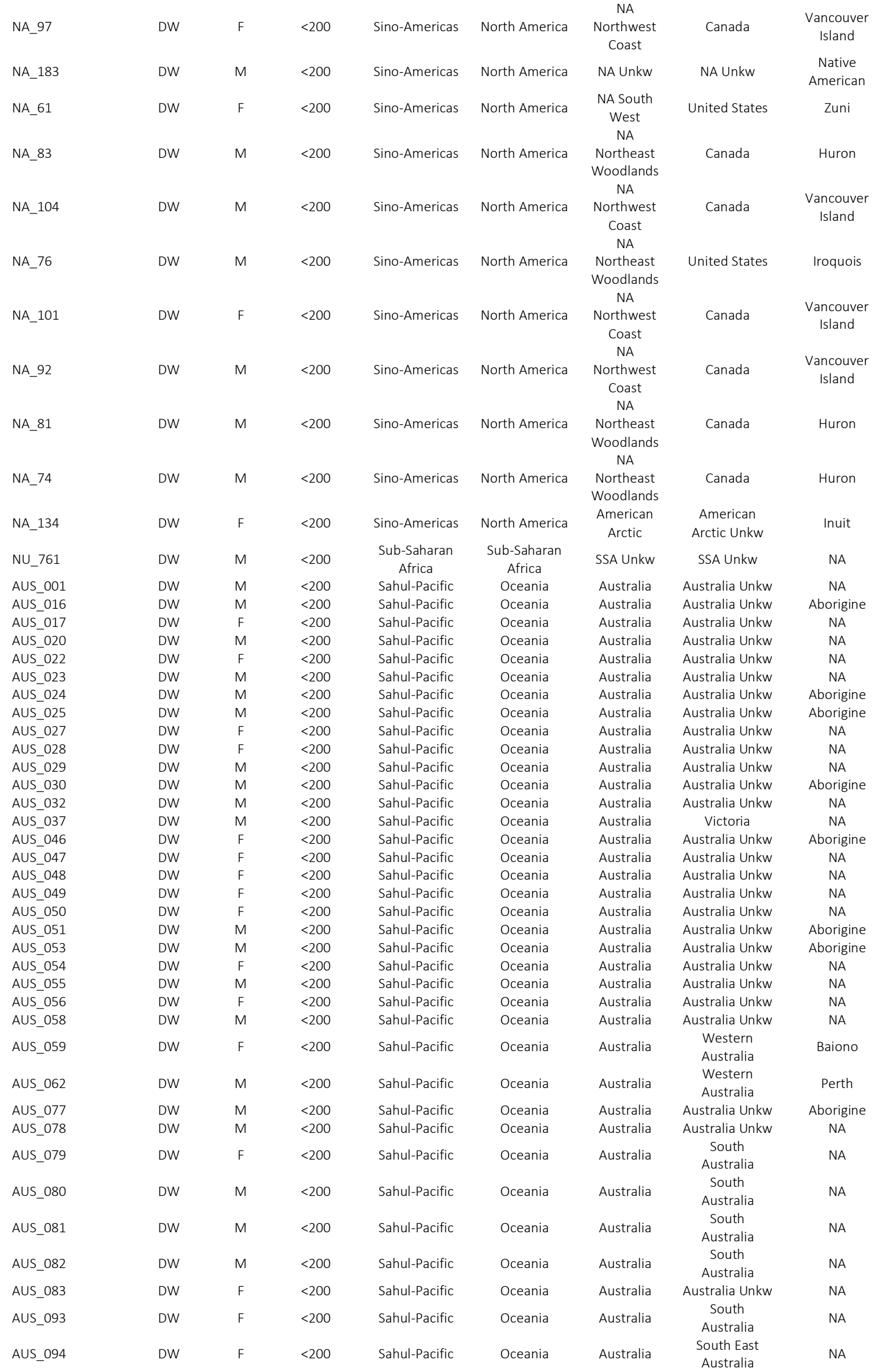


bioRxiv preprint doi: https://doi.org/10.1101/2022.02.01.478656; this version posted February 3, 2022. The copyright holder for this preprint (which was not certified by peer review) is the author/funder, who has granted bioRxiv a license to display the preprint in perpetuity. It is made available under aCC-BY-NC-ND 4.0 International license.

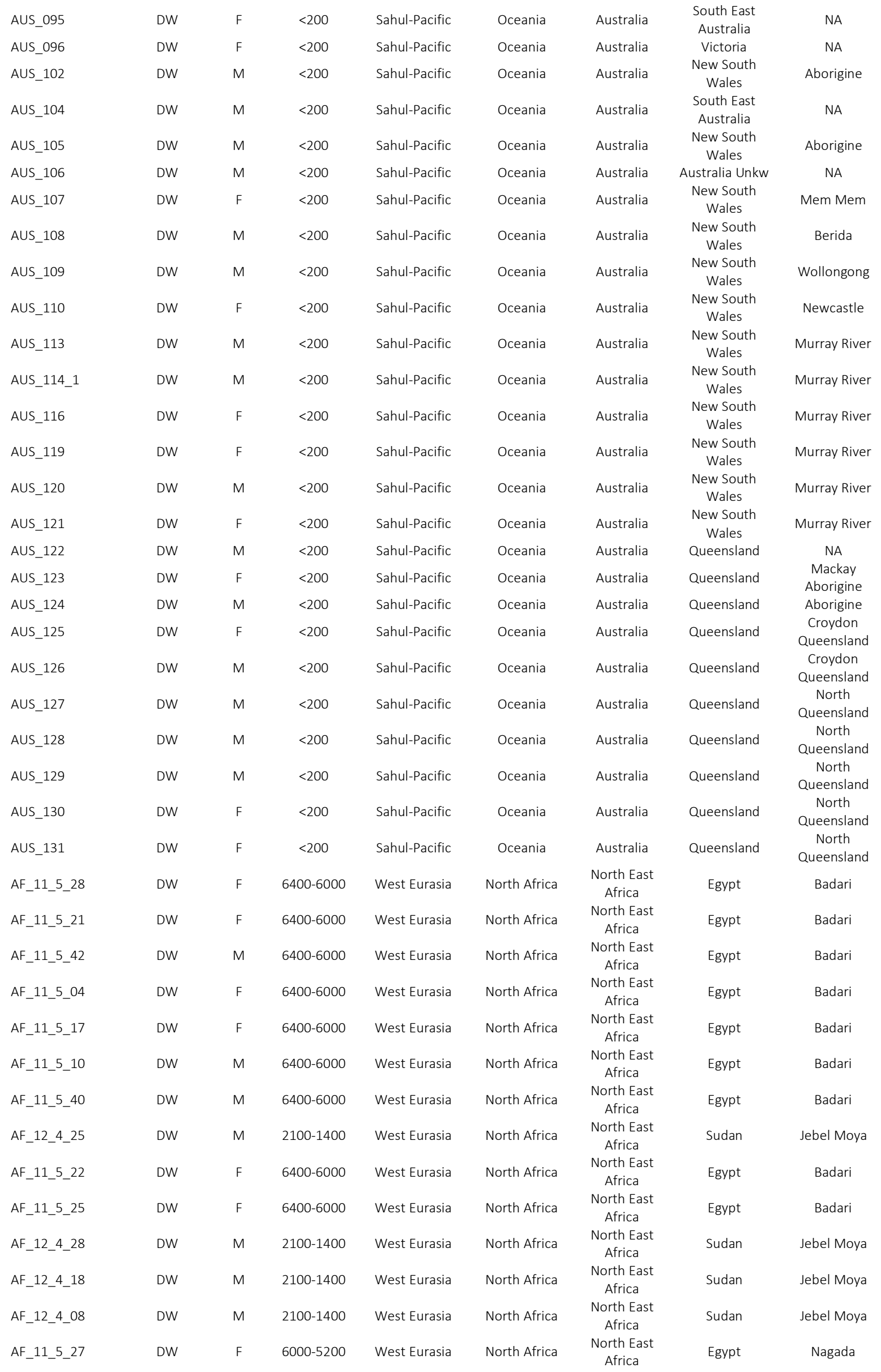


bioRxiv preprint doi: https://doi.org/10.1101/2022.02.01.478656; this version posted February 3, 2022. The copyright holder for this preprint (which was not certified by peer review) is the author/funder, who has granted bioRxiv a license to display the preprint in perpetuity. It is made available under aCC-BY-NC-ND 4.0 International license.

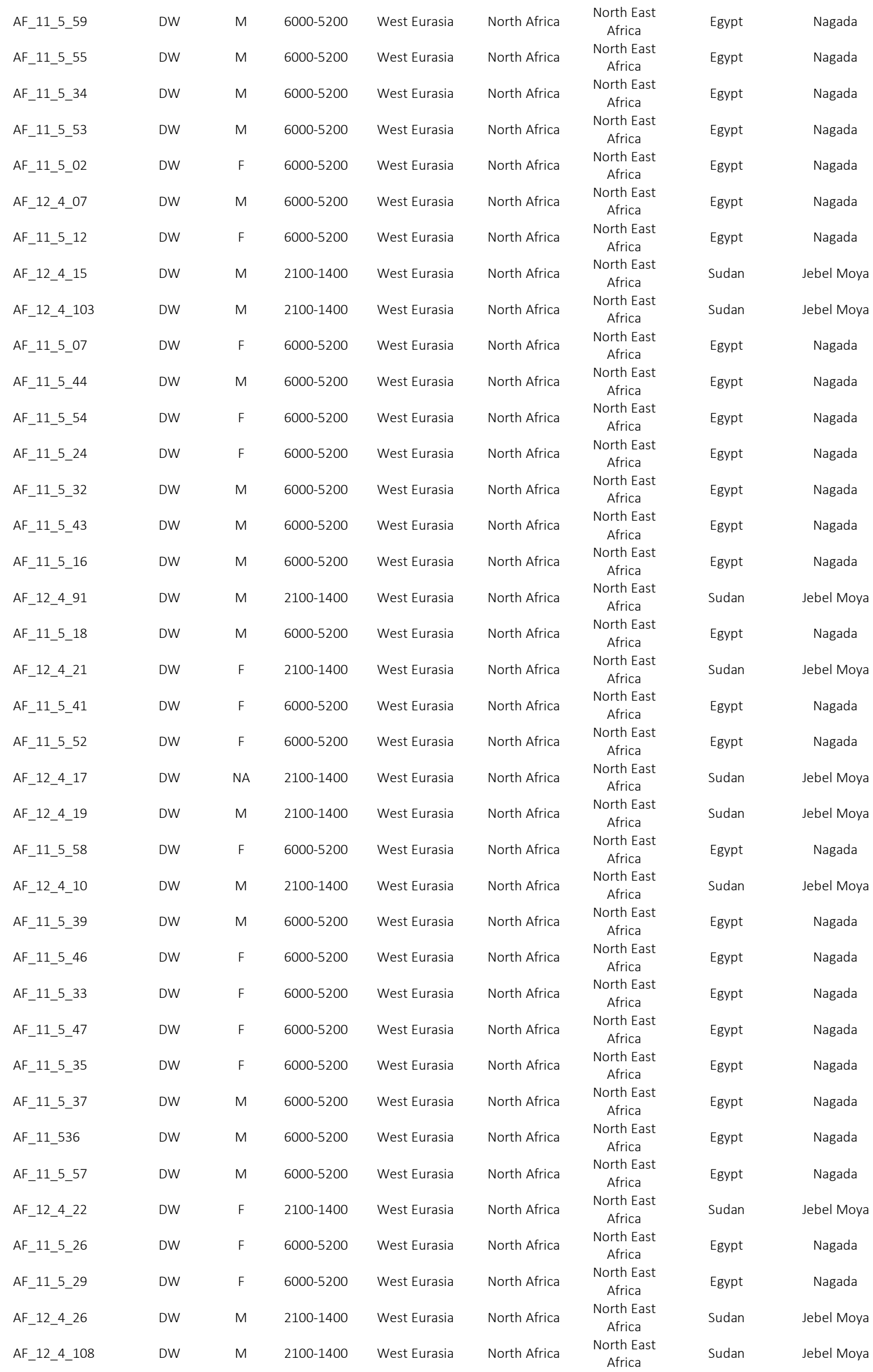


bioRxiv preprint doi: https://doi.org/10.1101/2022.02.01.478656; this version posted February 3, 2022. The copyright holder for this preprint (which was not certified by peer review) is the author/funder, who has granted bioRxiv a license to display the preprint in perpetuity. It is made available under aCC-BY-NC-ND 4.0 International license.

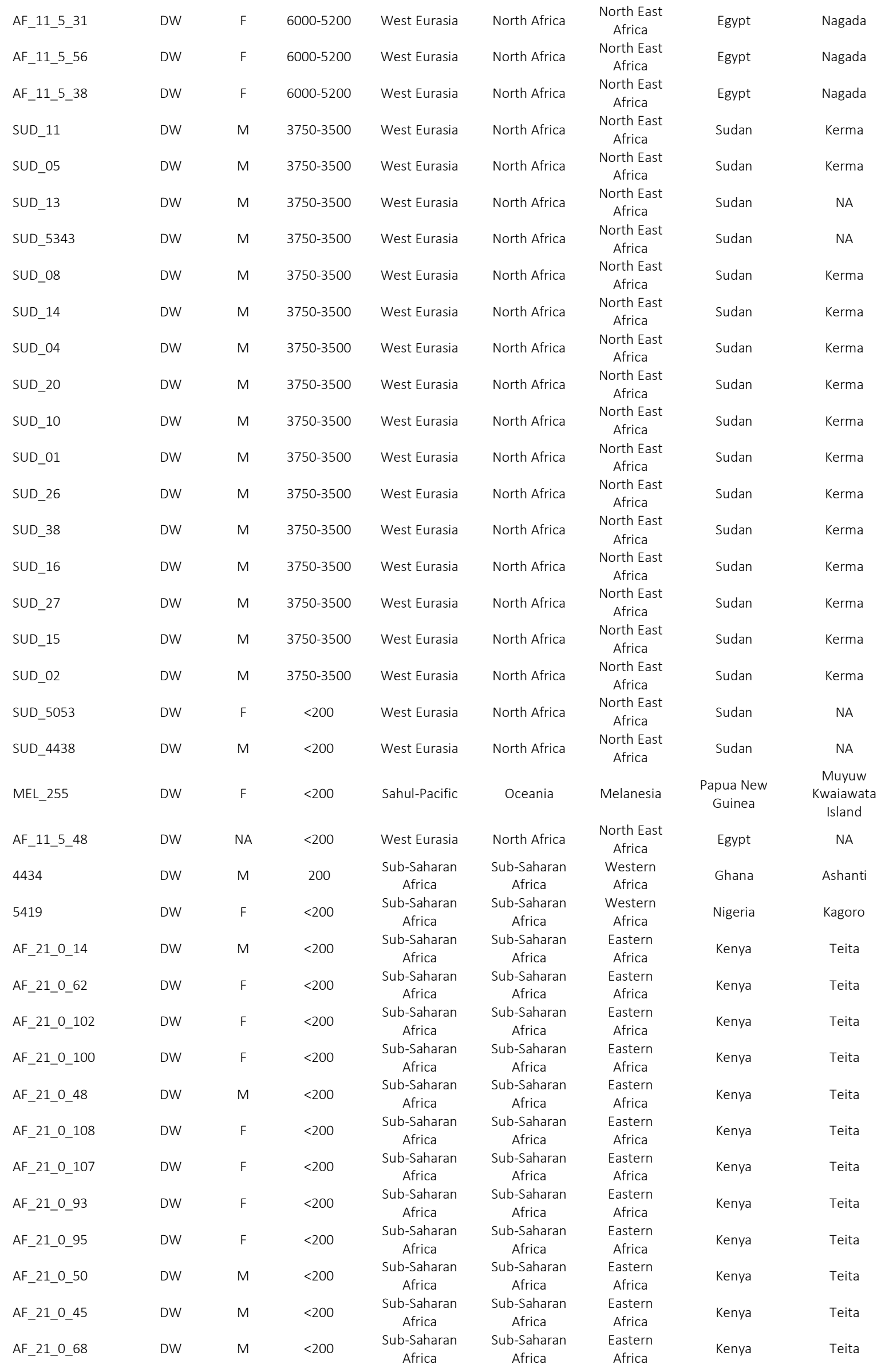


bioRxiv preprint doi: https://doi.org/10.1101/2022.02.01.478656; this version posted February 3, 2022. The copyright holder for this preprint (which was not certified by peer review) is the author/funder, who has granted bioRxiv a license to display the preprint in perpetuity. It is made available under aCC-BY-NC-ND 4.0 International license.

\begin{tabular}{|c|c|c|c|c|c|c|c|c|}
\hline AF_21_0_71 & DW & $\mathrm{F}$ & $<200$ & $\begin{array}{c}\text { Sub-Saharan } \\
\text { Africa }\end{array}$ & $\begin{array}{c}\text { Sub-Saharan } \\
\text { Africa }\end{array}$ & $\begin{array}{c}\text { Eastern } \\
\text { Africa }\end{array}$ & Kenya & Teita \\
\hline AF_21_0_41 & DW & M & $<200$ & $\begin{array}{c}\text { Sub-Saharan } \\
\text { Africa }\end{array}$ & $\begin{array}{c}\text { Sub-Saharan } \\
\text { Africa }\end{array}$ & $\begin{array}{c}\text { Eastern } \\
\text { Africa }\end{array}$ & Kenya & Teita \\
\hline AF_21_0_82 & DW & $\mathrm{F}$ & $<200$ & $\begin{array}{c}\text { Sub-Saharan } \\
\text { Africa }\end{array}$ & $\begin{array}{c}\text { Sub-Saharan } \\
\text { Africa }\end{array}$ & $\begin{array}{l}\text { Eastern } \\
\text { Africa }\end{array}$ & Kenya & Teita \\
\hline AF_21_0_94 & DW & $\mathrm{F}$ & $<200$ & $\begin{array}{c}\text { Sub-Saharan } \\
\text { Africa }\end{array}$ & $\begin{array}{c}\text { Sub-Saharan } \\
\text { Africa }\end{array}$ & $\begin{array}{l}\text { Eastern } \\
\text { Africa }\end{array}$ & Kenya & Teita \\
\hline AF_21_0_67 & DW & $\mathrm{F}$ & $<200$ & $\begin{array}{c}\text { Sub-Saharan } \\
\text { Africa }\end{array}$ & $\begin{array}{c}\text { Sub-Saharan } \\
\text { Africa }\end{array}$ & $\begin{array}{l}\text { Eastern } \\
\text { Africa }\end{array}$ & Kenya & Teita \\
\hline AF_21_0_70 & DW & $\mathrm{F}$ & $<200$ & $\begin{array}{c}\text { Sub-Saharan } \\
\text { Africa }\end{array}$ & $\begin{array}{c}\text { Sub-Saharan } \\
\text { Africa }\end{array}$ & $\begin{array}{l}\text { Eastern } \\
\text { Africa }\end{array}$ & Kenya & Teita \\
\hline AF_21_0_60 & DW & $\mathrm{M}$ & $<200$ & $\begin{array}{c}\text { Sub-Saharan } \\
\text { Africa }\end{array}$ & $\begin{array}{c}\text { Sub-Saharan } \\
\text { Africa }\end{array}$ & $\begin{array}{l}\text { Eastern } \\
\text { Africa }\end{array}$ & Kenya & Teita \\
\hline AF_21_0_34 & DW & M & $<200$ & $\begin{array}{c}\text { Sub-Saharan } \\
\text { Africa }\end{array}$ & $\begin{array}{c}\text { Sub-Saharan } \\
\text { Africa }\end{array}$ & $\begin{array}{l}\text { Eastern } \\
\text { Africa }\end{array}$ & Kenya & Teita \\
\hline AF_21_0_24 & DW & M & $<200$ & $\begin{array}{c}\text { Sub-Saharan } \\
\text { Africa }\end{array}$ & $\begin{array}{c}\text { Sub-Saharan } \\
\text { Africa }\end{array}$ & $\begin{array}{l}\text { Eastern } \\
\text { Africa }\end{array}$ & Kenya & Teita \\
\hline AF_21_0_9 & DW & M & $<200$ & $\begin{array}{c}\text { Sub-Saharan } \\
\text { Africa }\end{array}$ & $\begin{array}{c}\text { Sub-Saharan } \\
\text { Africa }\end{array}$ & $\begin{array}{l}\text { Eastern } \\
\text { Africa }\end{array}$ & Kenya & Teita \\
\hline AF_21_0_20 & DW & M & $<200$ & $\begin{array}{c}\text { Sub-Saharan } \\
\text { Africa }\end{array}$ & $\begin{array}{c}\text { Sub-Saharan } \\
\text { Africa }\end{array}$ & $\begin{array}{l}\text { Eastern } \\
\text { Africa }\end{array}$ & Kenya & Teita \\
\hline AF_21_0_18 & DW & M & $<200$ & $\begin{array}{c}\text { Sub-Saharan } \\
\text { Africa }\end{array}$ & $\begin{array}{c}\text { Sub-Saharan } \\
\text { Africa }\end{array}$ & $\begin{array}{l}\text { Eastern } \\
\text { Africa }\end{array}$ & Kenya & Teita \\
\hline AF_21_0_43 & DW & M & $<200$ & $\begin{array}{c}\text { Sub-Saharan } \\
\text { Africa }\end{array}$ & $\begin{array}{c}\text { Sub-Saharan } \\
\text { Africa }\end{array}$ & $\begin{array}{l}\text { Eastern } \\
\text { Africa }\end{array}$ & Kenya & Teita \\
\hline AF_21_0_16 & DW & M & $<200$ & $\begin{array}{c}\text { Sub-Saharan } \\
\text { Africa }\end{array}$ & $\begin{array}{c}\text { Sub-Saharan } \\
\text { Africa }\end{array}$ & $\begin{array}{l}\text { Eastern } \\
\text { Africa }\end{array}$ & Kenya & Teita \\
\hline AF_21_0_13 & DW & M & $<200$ & $\begin{array}{c}\text { Sub-Saharan } \\
\text { Africa }\end{array}$ & $\begin{array}{c}\text { Sub-Saharan } \\
\text { Africa }\end{array}$ & $\begin{array}{l}\text { Eastern } \\
\text { Africa }\end{array}$ & Kenya & Teita \\
\hline AF_21_0_40 & DW & M & $<200$ & $\begin{array}{c}\text { Sub-Saharan } \\
\text { Africa }\end{array}$ & $\begin{array}{c}\text { Sub-Saharan } \\
\text { Africa }\end{array}$ & $\begin{array}{l}\text { Eastern } \\
\text { Africa }\end{array}$ & Kenya & Teita \\
\hline AF_21_0_25 & DW & M & $<200$ & $\begin{array}{c}\text { Sub-Saharan } \\
\text { Africa }\end{array}$ & $\begin{array}{c}\text { Sub-Saharan } \\
\text { Africa }\end{array}$ & $\begin{array}{c}\text { Eastern } \\
\text { Africa }\end{array}$ & Kenya & Teita \\
\hline AF_21_0_12 & DW & M & $<200$ & $\begin{array}{c}\text { Sub-Saharan } \\
\text { Africa }\end{array}$ & $\begin{array}{c}\text { Sub-Saharan } \\
\text { Africa }\end{array}$ & $\begin{array}{l}\text { Eastern } \\
\text { Africa }\end{array}$ & Kenya & Teita \\
\hline AF_21_0_29 & DW & M & $<200$ & $\begin{array}{c}\text { Sub-Saharan } \\
\text { Africa }\end{array}$ & $\begin{array}{c}\text { Sub-Saharan } \\
\text { Africa }\end{array}$ & $\begin{array}{l}\text { Eastern } \\
\text { Africa }\end{array}$ & Kenya & Teita \\
\hline AF_21_0_118 & DW & $\mathrm{F}$ & $<200$ & $\begin{array}{c}\text { Sub-Saharan } \\
\text { Africa }\end{array}$ & $\begin{array}{c}\text { Sub-Saharan } \\
\text { Africa }\end{array}$ & $\begin{array}{c}\text { Eastern } \\
\text { Africa }\end{array}$ & Kenya & Teita \\
\hline AF_21_0_121 & DW & $\mathrm{F}$ & $<200$ & $\begin{array}{c}\text { Sub-Saharan } \\
\text { Africa }\end{array}$ & $\begin{array}{c}\text { Sub-Saharan } \\
\text { Africa }\end{array}$ & $\begin{array}{c}\text { Eastern } \\
\text { Africa }\end{array}$ & Kenya & Teita \\
\hline AF_21_0_133 & DW & $\mathrm{F}$ & $<200$ & $\begin{array}{c}\text { Sub-Saharan } \\
\text { Africa }\end{array}$ & $\begin{array}{c}\text { Sub-Saharan } \\
\text { Africa }\end{array}$ & $\begin{array}{c}\text { Eastern } \\
\text { Africa }\end{array}$ & Kenya & Teita \\
\hline AF_21_0_129 & DW & $\mathrm{F}$ & $<200$ & $\begin{array}{c}\text { Sub-Saharan } \\
\text { Africa }\end{array}$ & $\begin{array}{c}\text { Sub-Saharan } \\
\text { Africa }\end{array}$ & $\begin{array}{l}\text { Eastern } \\
\text { Africa }\end{array}$ & Kenya & Teita \\
\hline AF_21_0_123 & DW & $\mathrm{F}$ & $<200$ & $\begin{array}{c}\text { Sub-Saharan } \\
\text { Africa }\end{array}$ & $\begin{array}{c}\text { Sub-Saharan } \\
\text { Africa }\end{array}$ & $\begin{array}{c}\text { Eastern } \\
\text { Africa }\end{array}$ & Kenya & Teita \\
\hline AF_21_0_126 & DW & $\mathrm{F}$ & $<200$ & $\begin{array}{c}\text { Sub-Saharan } \\
\text { Africa }\end{array}$ & $\begin{array}{c}\text { Sub-Saharan } \\
\text { Africa }\end{array}$ & $\begin{array}{l}\text { Eastern } \\
\text { Africa }\end{array}$ & Kenya & Teita \\
\hline AF_21_0_113 & DW & M & $<200$ & $\begin{array}{c}\text { Sub-Saharan } \\
\text { Africa }\end{array}$ & $\begin{array}{c}\text { Sub-Saharan } \\
\text { Africa }\end{array}$ & $\begin{array}{c}\text { Eastern } \\
\text { Africa }\end{array}$ & Kenya & Teita \\
\hline 1742 & DW & $\mathrm{F}$ & $<200$ & $\begin{array}{c}\text { Sub-Saharan } \\
\text { Africa }\end{array}$ & $\begin{array}{c}\text { Sub-Saharan } \\
\text { Africa }\end{array}$ & $\begin{array}{c}\text { Southern } \\
\text { Africa }\end{array}$ & South Africa & NA \\
\hline AF_23_0_28 & DW & $\mathrm{F}$ & $<200$ & $\begin{array}{c}\text { Sub-Saharan } \\
\text { Africa }\end{array}$ & $\begin{array}{c}\text { Sub-Saharan } \\
\text { Africa }\end{array}$ & $\begin{array}{c}\text { Eastern } \\
\text { Africa }\end{array}$ & Tanzania & Bukoba \\
\hline AF_15_0_2 & DW & M & $<200$ & $\begin{array}{c}\text { Sub-Saharan } \\
\text { Africa }\end{array}$ & $\begin{array}{c}\text { Sub-Saharan } \\
\text { Africa }\end{array}$ & $\begin{array}{l}\text { Eastern } \\
\text { Africa }\end{array}$ & Somalia & Hariya \\
\hline AF112 & DW & $\mathrm{F}$ & $<200$ & $\begin{array}{c}\text { Sub-Saharan } \\
\text { Africa }\end{array}$ & $\begin{array}{c}\text { Sub-Saharan } \\
\text { Africa }\end{array}$ & $\begin{array}{l}\text { Southern } \\
\text { Africa }\end{array}$ & South Africa & NA \\
\hline SAS_14 & DW & M & $<200$ & West Eurasia & South Asia & $\begin{array}{l}\text { Indian Sub- } \\
\text { Continent }\end{array}$ & Pakistan & NA \\
\hline 209305 & $\mathrm{NMNH}$ & M & $<200$ & Sunda-Pacific & $\begin{array}{c}\text { South East } \\
\text { Asia }\end{array}$ & $\begin{array}{c}\text { Malay } \\
\text { Archipelago }\end{array}$ & Philippines & Tagalog Island \\
\hline 209307 & $\mathrm{NMNH}$ & $\mathrm{F}$ & $<200$ & Sunda-Pacific & $\begin{array}{c}\text { South East } \\
\text { Asia }\end{array}$ & $\begin{array}{c}\text { Malay } \\
\text { Archipelago }\end{array}$ & Philippines & Tagalog Island \\
\hline 209310 & $\mathrm{NMNH}$ & $\mathrm{F}$ & $<200$ & Sunda-Pacific & $\begin{array}{c}\text { South East } \\
\text { Asia }\end{array}$ & $\begin{array}{c}\text { Malay } \\
\text { Archipelago }\end{array}$ & Philippines & Tagalog Island \\
\hline 226155 & $\mathrm{NMNH}$ & $\mathrm{F}$ & $<200$ & Sahul-Pacific & Oceania & Polynesia & New Zealand & NA \\
\hline 226156 & NMNH & $\mathrm{F}$ & $<200$ & Sahul-Pacific & Oceania & Polynesia & New Zealand & NA \\
\hline 226158 & $\mathrm{NMNH}$ & M & $<200$ & Sahul-Pacific & Oceania & Polynesia & New Zealand & NA \\
\hline 222001 & $\mathrm{NMNH}$ & M & $<200$ & Sunda-Pacific & $\begin{array}{c}\text { South East } \\
\text { Asia }\end{array}$ & $\begin{array}{c}\text { Malay } \\
\text { Archipelago }\end{array}$ & Indonesia & Pagi Island \\
\hline 381079 & $\mathrm{NMNH}$ & $\mathrm{F}$ & $<200$ & Sahul-Pacific & Oceania & Melanesia & $\begin{array}{c}\text { Papua New } \\
\text { Guinea }\end{array}$ & New Britain \\
\hline
\end{tabular}


bioRxiv preprint doi: https://doi.org/10.1101/2022.02.01.478656; this version posted February 3, 2022. The copyright holder for this preprint (which was not certified by peer review) is the author/funder, who has granted bioRxiv a license to display the preprint in perpetuity. It is made available under aCC-BY-NC-ND 4.0 International license.

\begin{tabular}{|c|c|c|c|c|c|c|c|c|}
\hline 99_1_109 & $\mathrm{NMNH}$ & M & $\sim 1600$ & Sino-Americas & North America & $\begin{array}{c}\text { American } \\
\text { Arctic }\end{array}$ & Alaska & Ipiutak \\
\hline 99_1_199 & $\mathrm{NMNH}$ & $F$ & $\sim 1600$ & Sino-Americas & North America & $\begin{array}{c}\text { American } \\
\text { Arctic }\end{array}$ & Alaska & Ipiutak \\
\hline 99_1_209 & $\mathrm{NMNH}$ & M & $\sim 1600$ & Sino-Americas & North America & $\begin{array}{c}\text { American } \\
\text { Arctic }\end{array}$ & Alaska & Ipiutak \\
\hline 99_1_211 & $\mathrm{NMNH}$ & $\mathrm{F}$ & $\sim 1600$ & Sino-Americas & North America & $\begin{array}{c}\text { American } \\
\text { Arctic }\end{array}$ & Alaska & Ipiutak \\
\hline 99_1_174 & $\mathrm{NMNH}$ & $\mathrm{F}$ & $\sim 1600$ & Sino-Americas & North America & $\begin{array}{c}\text { American } \\
\text { Arctic }\end{array}$ & Alaska & NA \\
\hline 99_1_568 & $\mathrm{NMNH}$ & M & $\sim 1600$ & Sino-Americas & North America & $\begin{array}{l}\text { American } \\
\text { Arctic }\end{array}$ & Alaska & NA \\
\hline 99_1_594 & $\mathrm{NMNH}$ & $M$ & $\sim 1600$ & Sino-Americas & North America & $\begin{array}{l}\text { American } \\
\text { Arctic }\end{array}$ & Alaska & NA \\
\hline 99_1_593 & $\mathrm{NMNH}$ & $\mathrm{F}$ & $\sim 1600$ & Sino-Americas & North America & $\begin{array}{c}\text { American } \\
\text { Arctic }\end{array}$ & Alaska & NA \\
\hline 99_1_64 & $\mathrm{NMNH}$ & $\mathrm{F}$ & $\sim 800$ & Sino-Americas & North America & $\begin{array}{c}\text { American } \\
\text { Arctic }\end{array}$ & Alaska & Tigara \\
\hline 99_1_642 & $\mathrm{NMNH}$ & M & $\sim 800$ & Sino-Americas & North America & $\begin{array}{c}\text { American } \\
\text { Arctic }\end{array}$ & Alaska & Tigara \\
\hline 99_1_649 & $\mathrm{NMNH}$ & $M$ & $\sim 800$ & Sino-Americas & North America & $\begin{array}{c}\text { American } \\
\text { Arctic }\end{array}$ & Alaska & Tigara \\
\hline 99_1_222 & $\mathrm{NMNH}$ & $\mathrm{F}$ & $\sim 800$ & Sino-Americas & North America & $\begin{array}{c}\text { American } \\
\text { Arctic }\end{array}$ & Alaska & Tigara \\
\hline 99_1_231 & $\mathrm{NMNH}$ & M & $\sim 800$ & Sino-Americas & North America & $\begin{array}{c}\text { American } \\
\text { Arctic }\end{array}$ & Alaska & Tigara \\
\hline 99_1_231A & NMNH & $\mathrm{F}$ & $\sim 800$ & Sino-Americas & North America & $\begin{array}{c}\text { American } \\
\text { Arctic }\end{array}$ & Alaska & Tigara \\
\hline 99_1_232 & $\mathrm{NMNH}$ & $\mathrm{F}$ & $\sim 800$ & Sino-Americas & North America & $\begin{array}{c}\text { American } \\
\text { Arctic }\end{array}$ & Alaska & Tigara \\
\hline 99_1_260 & NMNH & $\mathrm{F}$ & $\sim 800$ & Sino-Americas & North America & $\begin{array}{c}\text { American } \\
\text { Arctic }\end{array}$ & Alaska & Tigara \\
\hline 99_1_262 & $\mathrm{NMNH}$ & $\mathrm{F}$ & $\sim 800$ & Sino-Americas & North America & $\begin{array}{c}\text { American } \\
\text { Arctic }\end{array}$ & Alaska & Tigara \\
\hline 99_1_402 & $\mathrm{NMNH}$ & $M$ & $\sim 800$ & Sino-Americas & North America & $\begin{array}{c}\text { American } \\
\text { Arctic }\end{array}$ & Alaska & Tigara \\
\hline 99_1_403 & $\mathrm{NMNH}$ & M & $\sim 800$ & Sino-Americas & North America & $\begin{array}{c}\text { American } \\
\text { Arctic }\end{array}$ & Alaska & Tigara \\
\hline 99_1_404 & $\mathrm{NMNH}$ & M & $\sim 800$ & Sino-Americas & North America & $\begin{array}{c}\text { American } \\
\text { Arctic }\end{array}$ & Alaska & Tigara \\
\hline 99_1_415 & $\mathrm{NMNH}$ & $\mathrm{F}$ & $\sim 800$ & Sino-Americas & North America & $\begin{array}{c}\text { American } \\
\text { Arctic }\end{array}$ & Alaska & Tigara \\
\hline 99_1_420 & $\mathrm{NMNH}$ & $\mathrm{F}$ & $\sim 800$ & Sino-Americas & North America & $\begin{array}{c}\text { American } \\
\text { Arctic }\end{array}$ & Alaska & Tigara \\
\hline 99_1_435 & $\mathrm{NMNH}$ & M & $\sim 800$ & Sino-Americas & North America & $\begin{array}{c}\text { American } \\
\text { Arctic }\end{array}$ & Alaska & Tigara \\
\hline 99_1_462 & $\mathrm{NMNH}$ & $M$ & $\sim 800$ & Sino-Americas & North America & $\begin{array}{c}\text { American } \\
\text { Arctic }\end{array}$ & Alaska & Tigara \\
\hline 99_1_503 & $\mathrm{NMNH}$ & $\mathrm{F}$ & $\sim 800$ & Sino-Americas & North America & $\begin{array}{c}\text { American } \\
\text { Arctic }\end{array}$ & Alaska & Tigara \\
\hline 226098 & NMNH & NA & $<200$ & Sahul-Pacific & Oceania & Melanesia & $\begin{array}{c}\text { Papua New } \\
\text { Guinea }\end{array}$ & New Britain \\
\hline 227454 & NMNH & NA & $<200$ & Sahul-Pacific & Oceania & Melanesia & $\begin{array}{c}\text { Papua New } \\
\text { Guinea }\end{array}$ & New Britain \\
\hline 227459 & $\mathrm{NMNH}$ & NA & $<200$ & Sahul-Pacific & Oceania & Melanesia & $\begin{array}{c}\text { Papua New } \\
\text { Guinea }\end{array}$ & New Britain \\
\hline 227465 & $\mathrm{NMNH}$ & NA & $<200$ & Sahul-Pacific & Oceania & Melanesia & $\begin{array}{c}\text { Papua New } \\
\text { Guinea }\end{array}$ & New Britain \\
\hline 242755 & $\mathrm{NMNH}$ & NA & $<200$ & Sino-Americas & North America & $\begin{array}{c}\text { American } \\
\text { Arctic }\end{array}$ & Canada & Baffin Island \\
\hline 242834 & $\mathrm{NMNH}$ & NA & $<200$ & Sino-Americas & North America & $\begin{array}{l}\text { American } \\
\text { Arctic }\end{array}$ & Canada & Baffin Island \\
\hline 259354 & $\mathrm{NMNH}$ & NA & $<200$ & Sunda-Pacific & $\begin{array}{c}\text { South East } \\
\text { Asia }\end{array}$ & $\begin{array}{c}\text { Malay } \\
\text { Archipelago }\end{array}$ & Philippines & NA \\
\hline 342024 & $\mathrm{NMNH}$ & NA & Unkw & Sino-Americas & North America & $\begin{array}{c}\text { American } \\
\text { Arctic }\end{array}$ & Greenland & Inuit \\
\hline 379058 & $\mathrm{NMNH}$ & NA & $<200$ & Sunda-Pacific & $\begin{array}{c}\text { South East } \\
\text { Asia }\end{array}$ & $\begin{array}{c}\text { Malay } \\
\text { Archipelago }\end{array}$ & Philippines & NA \\
\hline 380430 & $\mathrm{NMNH}$ & $\mathrm{F}$ & $<200$ & Sunda-Pacific & $\begin{array}{l}\text { South East } \\
\text { Asia }\end{array}$ & $\begin{array}{c}\text { Malay } \\
\text { Archipelago }\end{array}$ & NA & Malaysian \\
\hline 380447 & $\mathrm{NMNH}$ & $M$ & $<200$ & Sunda-Pacific & $\begin{array}{l}\text { South East } \\
\text { Asia }\end{array}$ & $\begin{array}{c}\text { Malay } \\
\text { Archipelago }\end{array}$ & NA & NA \\
\hline 380448 & $\mathrm{NMNH}$ & $M$ & $<200$ & Sunda-Pacific & $\begin{array}{c}\text { South East } \\
\text { Asia }\end{array}$ & $\begin{array}{c}\text { Malay } \\
\text { Archipelago }\end{array}$ & NA & Malaysian \\
\hline 380450 & $\mathrm{NMNH}$ & M & Unkw & Sahul-Pacific & Oceania & Australia & $\begin{array}{l}\text { Northern } \\
\text { Territory }\end{array}$ & $\begin{array}{l}\text { Crocodile } \\
\text { Island }\end{array}$ \\
\hline
\end{tabular}


bioRxiv preprint doi: https://doi.org/10.1101/2022.02.01.478656; this version posted February 3, 2022. The copyright holder for this preprint (which was not certified by peer review) is the author/funder, who has granted bioRxiv a license to display the preprint in perpetuity. It is made available under aCC-BY-NC-ND 4.0 International license.

1054

1055

1056

1057

1058

1059

1060

1061

1062

1063

1064

1065

1066

1067

1068

1069

1070

1071

1072

1073

1074

1075

1076

1077

1078

1079

1080

1081

1082

1083

ID = collection identification number, $\mathbf{M}=$ Male, $\mathbf{F}=$ female, ${ }^{*} \mathbf{B P}=$ before present, $\mathbf{D W}=$ Duckworth, $\mathbf{A M N H}=$ American Museum of Natural History, NMNH = Smithsonian National Museum of Natural History, +G1 = Major Human Subdivisions, G2 = Continental Group, G3 = Continental Region, G4 = Country/State, G5 = Locality/Tribe, Unkw = unknown

Table B: Tukey Pair-wise comparisons of from PGLM model of canal to root number by tooth

\begin{tabular}{lccccc}
\hline Contrast & Estimate & Odds Ratio & Std. Error & Z-value & $P$-value \\
\hline $\mathrm{P}^{3}-\mathrm{P}^{4}$ & 0.0911 & 1.0953 & 0.0123 & 7.4180 & $<.00001$ \\
$\mathrm{P}^{3}-\mathrm{M}^{1}$ & -0.6923 & 0.5004 & 0.0165 & -41.9106 & $<.00001$ \\
$\mathrm{P}^{3}-\mathrm{M}^{2}$ & -0.6476 & 0.5233 & 0.0165 & -39.2830 & $<.00001$ \\
$\mathrm{P}^{3}-\mathrm{M}^{3}$ & -0.6500 & 0.5221 & 0.0164 & -39.6955 & $<.00001$ \\
$\mathrm{P}^{3}-\mathrm{P}_{3}$ & 0.1272 & 1.1356 & 0.0129 & 9.8777 & $<.00001$ \\
$\mathrm{P}^{3}-\mathrm{P}_{4}$ & 0.1197 & 1.1272 & 0.0128 & 9.3303 & $<.00001$ \\
$\mathrm{P}^{3}-\mathrm{M}_{1}$ & -0.2871 & 0.7504 & 0.0186 & -15.4013 & $<.00001$ \\
$\mathrm{P}^{3}-\mathrm{M}_{2}$ & -0.3234 & 0.7237 & 0.0145 & -22.2508 & $<.00001$ \\
$\mathrm{P}^{3}-\mathrm{M}_{3}$ & -0.3557 & 0.7006 & 0.0141 & -25.1822 & $<.00001$ \\
$\mathrm{P}^{4}-\mathrm{M}^{1}$ & -0.7834 & 0.4569 & 0.0183 & -42.9011 & $<.00001$ \\
$\mathrm{P}^{4}-\mathrm{M}^{2}$ & -0.7386 & 0.4778 & 0.0183 & -40.3220 & $<.00001$ \\
$\mathrm{P}^{4}-\mathrm{M}^{3}$ & -0.7410 & 0.4766 & 0.0179 & -41.3743 & $<.00001$ \\
$\mathrm{P}^{4}-\mathrm{P}_{3}$ & 0.0361 & 1.0368 & 0.0073 & 4.9477 & $<.00001$ \\
$\mathrm{P}^{4}-\mathrm{P}_{4}$ & 0.0286 & 1.0290 & 0.0071 & 4.0477 & $<.00001$ \\
$\mathrm{P}^{4}-\mathrm{M}_{1}$ & -0.3782 & 0.6851 & 0.0208 & -18.1390 & $<.00001$ \\
$\mathrm{P}^{4}-\mathrm{M}_{2}$ & -0.4145 & 0.6607 & 0.0158 & -26.2447 & $<.00001$ \\
$\mathrm{P}^{4}-\mathrm{M}_{3}$ & -0.4468 & 0.6397 & 0.0152 & -29.4156 & $<.00001$ \\
$\mathrm{M}^{1}-\mathrm{M}^{2}$ & 0.0448 & 1.0458 & 0.0061 & 7.2915 & $<.00001$ \\
$\mathrm{M}^{1}-\mathrm{M}^{3}$ & 0.0423 & 1.0433 & 0.0072 & 5.8984 & $\mathbf{0 . 0 0 0 1}$ \\
$\mathrm{M}^{1}-\mathrm{P}_{3}$ & 0.8195 & 2.2694 & 0.0174 & 47.1051 & $<.00001$
\end{tabular}




\begin{tabular}{llllll}
$\mathrm{M}^{1}-\mathrm{P}_{4}$ & 0.8120 & 2.2525 & 0.0178 & 45.6536 & $<.00001$ \\
$\mathrm{M}^{1}-\mathrm{M}_{1}$ & 0.4052 & 1.4997 & 0.0055 & 73.7824 & $<.00001$ \\
$\mathrm{M}^{1}-\mathrm{M}_{2}$ & 0.3689 & 1.4461 & 0.0053 & 69.3361 & $<.00001$ \\
$\mathrm{M}^{1}-\mathrm{M}_{3}$ & 0.3366 & 1.4002 & 0.0055 & 61.0848 & $<.00001$ \\
$\mathrm{M}^{2}-\mathrm{M}^{3}$ & -0.0024 & 0.9976 & 0.0078 & -0.3101 & 0.0222 \\
$\mathrm{M}^{2}-\mathrm{P}_{3}$ & 0.7748 & 2.1701 & 0.0177 & 43.6840 & $<.00001$ \\
$\mathrm{M}^{2}-\mathrm{P}_{4}$ & 0.7673 & 2.1539 & 0.0181 & 42.3303 & $<.00001$ \\
$\mathrm{M}^{2}-\mathrm{M}_{1}$ & 0.3605 & 1.4340 & 0.0085 & 42.4873 & $<.00001$ \\
$\mathrm{M}^{2}-\mathrm{M}_{2}$ & 0.3241 & 1.3828 & 0.0071 & 45.3929 & $<.00001$ \\
$\mathrm{M}^{2}-\mathrm{M}_{3}$ & 0.2918 & 1.3389 & 0.0074 & 39.2476 & $<.00001$ \\
$\mathrm{M}^{3}-\mathrm{P}_{3}$ & 0.7772 & 2.1753 & 0.0174 & 44.7211 & $<.00001$ \\
$\mathrm{M}^{3}-\mathrm{P}_{4}$ & 0.7697 & 2.1591 & 0.0177 & 43.4366 & $<.00001$ \\
$\mathrm{M}^{3}-\mathrm{M}_{1}$ & 0.3629 & 1.4375 & 0.0094 & 38.4709 & $<.00001$ \\
$\mathrm{M}^{3}-\mathrm{M}_{2}$ & 0.3265 & 1.3862 & 0.0078 & 41.6325 & $<.00001$ \\
$\mathrm{M}^{3}-\mathrm{M}_{3}$ & 0.2942 & 1.3421 & 0.0080 & 36.9683 & $<.00001$ \\
$\mathrm{P}_{3}-\mathrm{P}_{4}$ & -0.0075 & 0.9925 & 0.0019 & -3.8619 & $<.00001$ \\
$\mathrm{P}_{3}-\mathrm{M}_{1}$ & -0.4143 & 0.6608 & 0.0200 & -20.6987 & $<.00001$ \\
$\mathrm{P}_{3}-\mathrm{M}_{2}$ & -0.4506 & 0.6372 & 0.0147 & -30.7287 & $<.00001$ \\
$\mathrm{P}_{3}-\mathrm{M}_{3}$ & -0.4829 & 0.6170 & 0.0141 & -34.2334 & $<.00001$ \\
$\mathrm{P}_{4}-\mathrm{M}_{1}$ & -0.4068 & 0.6658 & 0.0204 & -19.9481 & $<.00001$ \\
$\mathrm{P}_{4}-\mathrm{M}_{2}$ & -0.4431 & 0.6420 & 0.0151 & -29.3666 & $<.00001$ \\
$\mathrm{P}_{4}-\mathrm{M}_{3}$ & -0.4754 & 0.6216 & 0.0145 & -32.8780 & $<.00001$ \\
$\mathrm{M}_{1}-\mathrm{M}_{2}$ & -0.0364 & 0.9643 & 0.0078 & -4.6724 & $<.00001$ \\
$\mathrm{M}_{1}-\mathrm{M}_{3}$ & -0.0687 & 0.9336 & 0.0079 & -8.7160 & $<.00001$ \\
$\mathrm{M}_{2}-\mathrm{M}_{3}$ & -0.0323 & 0.9682 & 0.0050 & -6.4832 & $<.00001$ \\
\hline$D_{0}-5 t m$ & $B$ & $0.05 / 45 \approx$ & 0.001
\end{tabular}

1084 \# Does not meet Bonferroni correction of $0.05 / 45 \approx 0.001$, where 45 is the number of pair-wise tests. ${ }^{*}$ 1085 Significant values in bold after Bonferroni correction. Model fitted without intercept. Results are given on the $1086 \log$ (not the response) scale.

1087

1088

1089

1090

1091

1092

Table C: Tukey pair-wise comparisons of canal to root number by geographical region

\begin{tabular}{lccccc}
\hline Contrast & Estimate & $\begin{array}{l}\text { Odds } \\
\text { Ratio }\end{array}$ & Std. Error & z-ratio & $P$-value* \\
\hline Sahul-Pacific - Sino-Americas & -0.022 & 1.978 & 0.007 & -3.165 & 0.014 \\
Sahul-Pacific - Sub-Saharan Africa & -0.047 & 0.955 & 0.007 & -6.191 & $<.0001$ \\
Sahul-Pacific - Sunda-Pacific & -0.008 & 0.993 & 0.011 & -0.688 & 0.9591 \\
Sahul-Pacific - West Eurasia & 0.019 & 1.019 & 0.008 & 2.539 & 0.082 \\
Sino-Americas - Sub-Saharan Africa & -0.024 & 0.976 & 0.007 & -3.457 & $\mathbf{0 . 0 0 5}$ \\
Sino-Americas - Sunda-Pacific & -0.015 & 1.015 & 0.011 & 1.402 & 0.626 \\
Sino-Americas - West Eurasia & -0.003 & 0.997 & 0.007 & -0.438 & 0.992 \\
Sub-Saharan Africa - Sunda-Pacific & 0.039 & 1.040 & 0.011 & 3.584 & $\mathbf{0 . 0 0 3}$ \\
Sub-Saharan Africa - West Eurasia & -0.027 & 0.973 & 0.008 & -3.622 & $\mathbf{0 . 0 0 3}$ \\
Sunda-Pacific - West Eurasia & 0.012 & 1.012 & 0.008 & 1.066 & 0.824 \\
\hline
\end{tabular}

1093 Model fitted without intercept. Results are averaged over tooth. * significant values in bold. 